Revista de Derecho

de la Pontificia Universidad Católica de Valparaíso

XXX (Valparaíso, Chile, $1^{\text {er }}$ Semestre de 2008)

[pp. 61 - 153]

\title{
LA PIGNORACIÓN DE GRUPOS DE BIENES DE UNA MISMA CLASE O UNIVERSALIDADES DE HECHO EN LA NUEVA "LEY DE PRENDA SIN DESPLAZAMIENTO"
}

[Pledge of Groups of Goods of a Same Class or Universitas Facti in the

New "Law on Pledge Without Displacement"]

\author{
Alejandro Guzmán Brito* \\ Pontificia Universidad Católica de Valparaíso
}

\begin{abstract}
RESUMEN
El artículo 11 de la nueva Ley de prenda sin desplazamiento (2007) contiene la figura de una prenda sobre conjuntos que autoriza al pignorante para convertir sus originales componentes en bienes ulteriormente manufacturados, que quedan sometidos a un prenda legal, bajo la previsión de que el conjunto ha de ser recargado con nuevos componentes, que también quedan pignorados por subrogación de los elementos que se reemplazaron. La nueva norma sustituye la pignoración de existencias, contenida en la Ley No 18.112. Pero la prenda que configura viene montada sobre la noción de universalidad de hecho, que da una importante base dogmática para explicar sus consecuencias legales y extraer conse-
\end{abstract}

\begin{abstract}
Article 11 of the new Law on pledge without displacement (2007) contains the figure of a pledge over sets that authorises the pledger to convert the original components in goods finally manufactured that become subject to a legal pledge, under the foreseeability that the whole must be recharged with new components that, in turn, also become pledged by subrogation of the elements that were replaced. The new norm replaced the pledge of goods contained in Law No. 18.112. But the pledge herein set is based on the universitas facti notion, which gives an important dogmatic ground to explain its legal consequences and to withdraw consequences not stated in the text of the law. This work accurately examines the
\end{abstract}

* Doctor en Derecho por la Universidad de Navarra, Espańa; profesor titular de Derecho romano de la Facultad de Derecho de la Pontificia Universidad Católica de Valparaíso. Dirección postal: Avenida Brasil 2950, Valparaíso, Chile. Correo electrónico: aguzman@ucv.cl

Universitas facti: Group of property formed by the will of the owner and divisible by such owner. 
cuencias no declaradas en el texto de la ley. El trabajo examina exhaustivamente el régimen de esta nueva prenda.

Palabras Clave: Prenda - Prenda sin desplazamiento - Prenda de universalidades de hecho - Prenda de grupos de bienes de una misma clases. regime of this new pledge.

KeYwords: Pledge - Pledge without displacement - Pledge of universitas facti - Pledge of groups of goods of a same class.

\section{LA NUEVA “LEY DE PRENDA SIN DESPLAZAMIENTO”**}

La Ley No 20.190, publicada en el Diario Oficial de 5 de junio de 2007, que Introduce adecuaciones tributarias e institucionales para el fomento de la industria de capital de riesgo y continua el proceso de modernización del mercado de capitales, consta de veintitrés artículos permanentes y ocho transitorios. Su artículo 14 reza así: "Dicta normas sobre prenda sin desplazamiento y crea el Registro de Prendas sin Desplazamiento"; y en él se contienen, a su vez, cuarenta y dos artículos permanentes, distribuidos en ocho títulos, más un artículo único transitorio, que forma el título $9^{\circ}$. Cabe decir, pues, que el dicho artículo 14 de la Ley No 20.190 envuelve la que pudo ser una ley separada y única. En lo sucesivo, cuando hablemos de "la ley", sin otra especificación, de "la nueva ley" o de la Ley de prenda sin desplazamiento, la referencia es, pues, al articulado que se despliega en el interior del artículo 14 de la Ley No 20.190.

De acuerdo con el artículo 41 de la nueva ley, sus disposiciones comenzarán a regir después de noventa días contados desde la fecha en que se publique el decreto supremo que contenga el Reglamento del Registro de Prendas sin Desplazamiento (creado por su artículo 28) en el Diario Oficial. Ahora bien, a la fecha de haberse terminado este trabajo, tal decreto reglamentario no había sido emitido; lo cual no impide estudiar la ley misma, en lo que no dependa del contenido de ese reglamento.

\section{EL OBJETO DE LA PRENDA SIN DESPLAZAMIENTO EN GENERAL}

Acerca del objeto general sobre que puede recaer la prenda sin desplazamiento creada por esta ley, comparecen dos preceptos: el artículo 1, que

** La historia legislativa de la nueva Ley de prenda sin desplazamiento, a la que se recurre con alguna frecuencia aquí, puede consultarse en: Historia de la Ley $N^{o}$ 20.190 (Biblioteca del Congreso Nacional, 5 de junio de 2007) [visible en: http:// www.bcn.cl/histley/lfs/hdl-20190/HL20190.pdf]. Para citarla se emplea la abreviación: Historia. 
dispone: "El contrato de prenda sin desplazamiento tiene por objeto constituir una garantía sobre una o varias cosas corporales o incorporales muebles [...]"; y el artículo 5, que establece: "Podrá constituirse prenda sobre todo tipo de cosas corporales o incorporales muebles, presentes o futuras./ [inciso $2^{\circ}$ ] Las naves y aeronaves se regirán por sus leyes particulares". Esta última norma, como se observa, es más amplia que la del artículo 1. Aunque ambas coinciden en que el objeto de la prenda sin desplazamiento está constituido por "cosas corporales o incorporales muebles", el artículo 5 añade que estos tipos de cosas muebles pueden ser presentes o futuras; y el artículo 1 precisa que el objeto puede ser "una o varias" cosas muebles corporales o incorporales. Por otro lado, la dicción del inciso $2^{\circ}$ del artículo 5 reenvía las naves y aeronaves, queriendo, en realidad, decir la prenda sobre ellas, a sus leyes particulares ${ }^{1}$.

En síntesis, pues, la prenda sin desplazamiento recae sobre una o más cosas corporales o incorporales muebles, sean presentes, sean futuras. De acuerdo con el artículo 565 inciso $3^{\circ}$ CC., por "cosas incorporales" debemos entender los derechos, que son o reales o personales (artículo 576 CC.). Ahora bien, los derechos reales son muebles cuando se ejercen o recaen sobre cosas corporales muebles; y son de la misma clase los derechos personales cuando lo debido es una cosa corporal mueble (artículo 580 CC.). Si el derecho personal tiene por objeto un hecho debido, aquél es siempre mueble (artículo 581 CC.). Por cosa futura, en fin, se entiende la que no existe pero se espera que exista (artículo 1461 inciso $1^{\circ} \mathrm{CC}$.).

${ }^{1}$ En materia de naves y artefactos navales, que son cosas muebles, rige el siguiente esquema de garantías reales: las naves mayores pueden ser hipotecadas (artículo 866 C. de C.), pero no pignoradas (artículo 20 inciso $4^{\circ}$ de la Ley de navegación, contenida en el Decreto-ley No 2.222 (DO. de 31 mayo de 1978). Las naves y artefactos navales menores pueden ser pignorados (artículo 881 C. de C. y artículo 20 inciso $4^{\circ}$ de la Ley de navegación, cit.); y su prenda "se regirá por las respectivas normas legales, según la clase de prenda de que se trate" (artículo 20 inciso $4^{\circ}$ de la Ley de navegación, cit.). De acuerdo con ello, sobre estos últimos objetos puede recaer la prenda ordinaria con desplazamiento, regulada en el título $37^{\circ}$ del libro IV CC. El artículo 8 inciso $2^{\circ}$ de la Ley No 18.112: Sobre prenda sin desplazamiento, da por sentado que sobre naves menores puede recaer tal tipo de garantía, que debe entenderse extendida también a los artefactos navales menores, no mencionados expresamente, pero subsumidos en la amplia dicción del artículo 4 inciso $2^{\circ}$ de esa ley. La Ley No 20.190 no menciona a las naves ni a los artefactos menores, porque, como estamos viendo, cree que, aparte el Código Civil, hay normas particulares sobre su prenda; pero ambos deben entenderse incluidos en la también amplia dicción de los artículos 1 y 5; así que, en síntesis, la Ley de prenda sin desplazamiento se aplica a las naves y artefactos menores. El artículo 114 del Código Aeronáutico, permite hipotecar las aeronaves; e indirectamente prohíbe su pignoración, al vetar otras garantías reales sobre ellas (inciso $4^{\circ}$ ). 


\section{EL TEMA DEL PRESENTE TRABAJO}

1. Nos proponemos estudiar el artículo 11 de la ley y el 12, que se conecta vigorosa aunque no exclusivamente con aquél. Dichos artículos hacen parte del título 2o, rubricado: De las obligaciones caucionadas y los bienes prendados. Por lo que atañe a las obligaciones "caucionadas", vale decir, caucionables que él mienta, la primera disposición del título, que es su artículo 4, dispone: "Podrán caucionarse con esta prenda cualquier clase de obligaciones, presentes o futuras, estén o no determinadas a la fecha del contrato". En lo concerniente a los bienes "prendados", o pignorables referidos en la rúbrica, está el artículo 5, cuyo texto transcribimos antes. En los artículos sucesivos del título $2^{\circ}$, hasta el 14, con excepción del 13, que trata de otros puntos, se prescribe sobre diversos tipos específicos de bienes pignorables, aunque en ocasiones vayan entremezcladas con cada uno de aquéllos ciertas referencias a las obligaciones caucionables. En consecuencia, el artículo 11 forma parte de esta serie de disposiciones sobre tipos específicos de bienes pignorables, que se inicia con el artículo 6 y llega hasta el 12 y salta al 14. En aquél se trata de la prenda sin desplazamiento aplicada a los grupos de bienes de una misma clase o universalidades de hecho, a los que nos contraemos en este trabajo. Por lo general, emplearemos la expresión "conjuntos” para referirnos más abreviadamente a ambos.

Menester es advertir todavía que el sentido de los artículos 6 a 12 y 14 no es el de autorizar la prenda sin desplazamiento sobre las cosas que en cada cual se señalan, de manera que sin ellos no se pudieran pignorar. En realidad, todas las cosas señaladas en esos artículos son pignorables ya merced a lo dispuesto de manera general por los artículos 1 y 5 , antes examinados, pues las cosas mencionadas en cada uno están incluidas en su amplia dicción de "cosas corporales o incorporales muebles". Los mencionados artículos 6 a 12 y 14 sólo se justifican, pues, en cuanto fijan un cierto estatuto o régimen para su pignoración. La única excepción es el artículo 14, que trata de los inmuebles por destinación o por adherencia como objetos de la prenda, ya que, sin él, hubiera resultado dudosa su pignoración, atendido que se trata precisamente de inmuebles; sin perjuicio de que, aclarado el punto, también la norma señala un régimen a la pignoración de tales inmuebles. 
1. La prenda de que trata el artículo 11 sustituye a la regulada por el artículo 6 de la Ley No 18.112, de 1982.

a) Esta norma configuró una prenda sobre lo que genéricamente denominó "existencias" (de mercaderías, materias primas, productos elaborados o semielaborados, repuestos y en general, de cualquier actividad proveniente de la producción o de los servicios). Ella, por lo demás, superó las limitaciones a la prenda de existencias que en materia agraria (Ley No 4.097, de 1926) e industrial (Ley No 5.687, de 1935)² impusieron las respectivas normas en razón de la especialidad del deudor, del acreedor, del objeto y de la deuda. La prenda de existencias de la Ley No 18.112 es, en efecto, general y común, tal como general y común es la prenda del artículo 11 de la nueva ley.

b) Según quedó expresado en el "Mensaje" del proyecto de la futura Ley No 20.190, con las normas finalmente incrustadas en el artículo 11 se quiso introducir en Chile la que, por influencia de la práctica anglosajona, suele denominarse "prenda flotante"3 ("floating charge" o "floating security"); en otros países también se la denomina "garantía global" o "garantía rotativa". Se trata de metáforas, algo ambiguas o impropias ${ }^{4}$, que es mejor no usar.

Independientemente de la denominación, esta prenda se caracteriza

${ }^{2}$ Empleamos la genérica expresión "existencias", aunque ella no aparece en las leyes No 4.097, sobre prenda agraria, y No 5.687, sobre prenda industrial, si bien los objetos pignorables según una y otra son precisamente lo que denota dicha expresión.

${ }^{3} \mathrm{El}$ "Mensaje", en efecto, al describir las innovaciones que proponía en materia de prenda sin desplazamiento, dijo que: "Se permite la denominada prenda flotante" (véase Historia, p. 27). La expresión volvió a aparecer en el curso de la discusión (véase Historia, pp. 306, 336 y 701).

${ }^{4}$ Véase: Marsal Guillamet, Joan, Las prendas flotantes. Un término polisémico, en Lauroba, M. Elena - Marsal, Joan, (editores), Garantías reales mobiliarias en Europa (Madrid, Marcial Pons, 2006), pp. 355-366. La prenda se llama flotante, porque la garantía "flota", es decir, se mantiene sobre una "superficie cambiante", constituida por las cambiantes cosas pignoradas; pero también se puede llamar así a la prenda que flota sobre una superficie de cambiantes deudas garantizadas. En todo caso, la prenda, como veremos, no siempre "flota". El adjetivo "global" no dice nada concreto. Que la prenda sea "rotativa" (adjetivo usual entre los juristas italianos), vale decir, que gira o rota en torno a un eje, no se entiende, porque aquello no acontece; ni tampoco se puede aplicar a las cosas pignoradas, que no rotan, en el sentido de circular constantemente, por más que unas salgan y otras entren en el conjunto pignorado. 
por cinco rasgos: i) inicialmente recae sobre una masa de cosas destinada por una empresa industrial a la fabricación de sus productos finales (materias primas, partes, piezas); o sobre la masa de bienes (mercaderías) que una empresa comercial destina a la venta a los distribuidores o a los consumidores; ii) el pignorante conserva la posesión de la correspondiente masa de bienes; iii) la pignoración no impide al industrial pignorante la transformación de las cosas pignoradas merced al normal proceso fabril ni la venta de los productos terminados; como tampoco se impide la venta de sus mercaderías al comerciante; iv) los productos y mercaderías, una vez vendidas, quedan libres de prenda; v) pero tanto los productos industriales elaborados, mientras no se vendan, como los elementos que ingresan para reponer la existencia consumida en la producción y continuar el proceso fabril; y las mercancías con que el comerciante se reaprovisiona para mantener su proceso mercantil, mientras no las venda, quedan en prenda. Se parte de la base, pues, que la masa inicial pignorada habrá de disiparse como consecuencia normal de los procesos industriales o comerciales, pero que será sustituida por nuevas masas, en un circuito interrumpido de disposiciones y reposiciones, que siempre prestan base a la garantía. Si llega el caso de su realización, el pignoratario puede proceder a ella con la masa en actual existencia, por más que sus individuos componentes sean muy distintos a los de la originalmente pignorada.

Adicionalmente, es propio de esta prenda su reiterabilidad a distintos acreedores sobre una misma masa de cosas; y la necesidad de que su contrato sea solemne y deba inscribirse en un registro único de prendas sin desplazamiento, para evitar que los potenciales acreedores deban consultar varias fuentes, antes de aceptar prendas.

2. Bajo la sola vigencia de las leyes precedentes, por lo general un régimen semejante propiamente no existió o existió imperfectamente.

a) El artículo 25 de la Ley No 5.687, de 1935, sobre prenda industrial $^{5}$, declara que la prenda establecida sobre materias primas queda ipso iure constituida sobre el producto elaborado con ellas. Tal es uno de los rasgos de la prenda que tratamos; pero su artículo 36 sólo permite la libre transferencia de los bienes pignorados, si previamente se paga la deuda garantizada, o si el acreedor autoriza la transferencia; en caso contrario, el acreedor puede exigir el pago al actual tenedor. La ley guardó silencio

\footnotetext{
${ }^{5}$ Sobre este tipo prendario, véase: Somarriva Undurraga, Manuel, Tratado de las cauciones (Santiago, Contable Chilena Editores, 1981), passim entre pp. 204-308; Lecaros Sánchez, José Miguel, Las cauciones reales. Prenda e hipoteca (Santiago, Metropolitana Ediciones, 2001), pp. 103-128; El MISMO, La prenda civil y las prendas especiales (2a edición, Santiago, Metropolitana Ediciones, 2005), pp. 107-131.
} 
sobre la reiterabilidad de esta prenda a distintos acreedores; pero establece la inscripción del contrato prendario en un registro especial (artículo 27).

Algo semejante configura el artículo 16 de la Ley No 4.097, de 1935, sobre prenda agraria ${ }^{6}$, en cuanto al objeto, pero no se refirió al caso de transformación de los productos inicialmente pignorados. En el resto, lo ya pignorado con esta prenda no puede volver a serlo (artículo 17). También se prevé la inscripción del contrato prendario en un registro especial (artículo 5).

b) La prenda de que tratamos, en cambio, sí recibió un perfil más pronunciado, y desde luego general y común, como antes quedó dicho, en la Ley No 18.112, de 1982, sobre prenda sin desplazamiento ${ }^{7}$, cuyo artículo 6 estableció: "Puede constituirse prenda sin desplazamiento sobre existencias de mercaderias, materias primas, productos elaborados o semielaborados $y$ repuestos del comercio o industrias $y$, en general, de cualquier actividad de la producción o de los servicios". Pero el inciso 2o libró a la voluntad de las partes el funcionamiento del esquema de la prenda antes presentado: "Los componentes de dichas existencias no podrán ser utilizados, transformados $o$ enajenados en todo o en parte, ni se podrá constituir sobre ellos ningún derecho a favor de terceros, sin previo consentimiento escrito del acreedor". Para ese caso, el inciso $3^{\circ}$ previó que: "[...] los bienes que salgan del conjunto empeñado quedan subrogados por los que posteriormente lo integren hasta la concurrencia del total constituido en prenda, quedando liberados de ella los comprendidos en la autorización que el acreedor diere para su enajenación". Nada expreso dijo esta ley acerca de la pignoración de los elementos con que se reponen las existencias gastadas en la producción, aunque se puede entender que ellos quedan involucrado en el concepto de "bienes que salgan del conjunto empeñado", de guisa que también resultan pignoradas, por subrogación, aquellos "que posteriormente lo integren" a título de reposición. Por lo demás, esta prenda no es reiterable sin permiso del acreedor (artículo 18); pero no está prevista su inscripción en un registro, que permita controlar la existencia de prendas, más sólo la publicación de un extracto del contrato en el Diario Oficial de ciertos días (artículo 9), que obliga a una larga consulta.

c) Fue bajo la influencia de la Ley No 18.112, que la Ley No 18.690,

\footnotetext{
${ }^{6}$ Sobre este tipo prendario, véase: Somarriva Undurraga, Manuel, Tratado de las cauciones (n. 5), passim pp. 204-308; LeCARos Sánchez, José Miguel, Las cauciones reales, cit. (n. 5), pp. 81-102; El mismo, La prenda civil, cit. (n. 5), pp. 85-106.

${ }^{7}$ Sobre la prenda de mercaderías depositadas en almacenes generales: LeCAROS SÁnchez, José Miguel, Las cauciones reales, cit. (n. 5), pp. 185-227; El MisMo, La prenda civil, cit. (n. 5), pp. 185-227.
} 
de 1988: Sobre almacenes generales de depósito ${ }^{8}$, estableció en su artículo 28 que el dueño de mercaderías depositadas en dichos almacenes y pignoradas mediante el endoso del vale de prenda, previo acuerdo con el almacenista y el acreedor prendario, puede reemplazar todo o parte de las mercaderías o productos depositados en el almacén por otros iguales o de similar calidad; y también transformar la mercadería depositadas. Añadió que, en este último caso, la prenda se entenderá constituida, por el solo ministerio de la ley y sin solución de continuidad, sobre el producto resultante de la operación transformadora, en cualquier grado de elaboración en que aquél se encuentre. La norma, pues, prevé algunos extremos importantes de la prenda sobre masas: la sustitución de componentes y su transformación, como también la pignoración legal de los productos de esta última; y, aunque omitió decirlo expresamente, parece subentender también que, en el caso de sustitución, el sustituyente queda asimismo en prenda ${ }^{9}$. Pero nada de esto es posible, como se ve, sin un acuerdo entre el pignorante y el pignoratario, al que debe concurrir además el almacenista.

3. El paso decisivo ha venido a ser dado por la nueva ley, que invirtió los términos de la precedente. Ahora, el régimen de la prenda de masas ya no es más accidental, sino natural, vale decir, rige en el silencio de las partes, las cuales, empero, pueden excluirlo merced a un pacto expreso (artículo 11 inciso 10: "salvo pacto en contrario").

Como a ella va dedicado el presente trabajo, nos abstendremos de adelantar los diversos puntos que incluye la nueva regulación.

Sólo anticiparemos un par de rasgos generales.

a) La principal novedad que aporta la nueva ley es no montar la prenda que regula sobre la base de las "existencias" -como, con diferente terminología suelen hacer las legislaciones extranjeras-, sino sobre las nociones de "grupos de bienes de la misma clases o universalidades de hecho". En su momento veremos que el primer extremo es una variedad del segundo; así que el concepto básico es el de universalidad de hecho. Esta decisión confiere un fundamento dogmático a la prenda del artículo 11, que explica sus características y su funcionamiento y la aleja del empirismo forense y judicial con que fue modernamente configurada la "floating charge" en el Derecho inglés del siglo XIX (desde 1870), aunque no del "Common

\footnotetext{
${ }^{8}$ Sobre este tipo prendario, véase: Lecaros Sánchez, José Miguel, Las cauciones reales, cit. (n. 5), pp. 148-158; El mismo, La prenda civil, cit. (n. ), pp. 150-159.

${ }^{9}$ Una norma semejante no aparece en la legislación anterior, que se remonta a la Ley No 3.896, de 1922, cuyo texto, antes de su derogación por la Ley No 18.690, de 1988, estaba fijada en el Decreto supremo (M. de Agricultura) No 178, de 27 de julio de 1981, publicado en el DO. de 29 de agosto del mismo año.
} 
law" sino de la "Equity"10.

Son, en efecto, las propiedades que ofrecen las universalidades de hecho las que permiten desarrollar una prenda sin desplazamiento de base real cambiante -los componentes de la universalidad pignorada-, aunque se mantenga inalterada su base ideal -la universalidad misma-. Pero tales propiedades fueron descubiertas, en realidad, por los juristas romanos ${ }^{11}$. La ley chilena, pese, por lo demás, a sus innumerables defectos de redacción, que en su momento recalcaremos, al menos ofrece este mérito de fundar la prenda que disciplina sobre una base perteneciente a su probada tradición jurídica. Conviene hacer notar que las leyes continentales, cuando han adoptado el modelo inglés, no suelen acudir a la noción de universalidad de hecho como fundamento dogmático, en el modo en que lo hace la nueva ley chilena. En este sentido, ésta tiene la virtud de haber rescatado ese fundamento romano.

b) La nueva prenda queda desligada del carácter industrial o comercial del pignorante, a diferencia de cuanto acaece en otras legislaciones y en contra de cuanto la experiencia y la realidad permiten prever, en orden a que los civiles vayan a usarla. Esta prenda, pues, ingresa en el Derecho común y general ${ }^{12}$.

c) Con una serie de derogaciones fulminadas por la ley en su artículo 42, han de quedar derogadas las siguientes prendas especiales: agraria, industrial y aquella sobre una cosa mueble comprada a plazo, amén de la general prenda sin desplazamiento de la Ley No 18.112. En este sentido, la nueva ley ha tendido a la unificación de las prendas sin desplazamiento, con escasas excepciones.

\section{HISTORIA LEGISLATIVA DE LA DESCRIPCIÓN DEL OBJETO PIGNORABLE SEGÚN EL INCISO 1º DEL ARTÍCULO 11 DE LA LEY No 20.190}

La especificidad del tipo de objeto pignorable a que se refiere el artículo 11 en su inciso $1^{\circ}$ consiste, como quedó dicho, en ser: "grupos de bienes de una misma clase o universalidades de hecho", a la cual fórmula sigue cierta enumeración ejemplar.

Es útil verificar que esta norma tenía otra redacción en el Mensaje del

${ }^{10}$ Acerca del proceso formativo de la "floating charge" en el Derecho inglés: Galanti, Enrico, Garanzia non possessoria e controllo della crisi di impresa: la "floating charge" el' "administrative receivership" (Banca d'Italia, Quaderni di ricerca giuridica della consulenza legale, No 51, 2000), pp. 15-20. Véase también: Veiga Copo, Abel Benito, Prenda 'omnibus', prenda rotativa de acciones y garantía flotante, en Revista de Derecho Bancario y Bursátil, Año 20, No 82 (Valladolid, 2001), especialmente pp. 61-72.

${ }^{11}$ Véase, más abajo, el capítulo VI, 3.

${ }^{12}$ Véase, más abajo, el capítulo X. 
Ejecutivo a la Cámara de Diputados, y que la de éste se basaba en la que ofrece el artículo 6 inciso $1^{\circ}$ de la Ley No 18.112: Sobre prenda sin desplazamiento, como puede observarse en la siguiente comparación ${ }^{13}$ :

Ley 18.112 , artículo 6 inciso $1^{\circ}$

"Puede constituirse prenda sin desplazamiento sobre

$$
\begin{gathered}
\text { “Mensaje", artículo } 5 \\
\text { incisos } 6^{\circ} \text { y } 70^{14}
\end{gathered}
$$

"La prenda establecida sobre materias primas, quedará ipso iure constituida sobre el producto elaborado. existencias de mercaderías, materias primas, productos elaborados o semielaborados y repuestos del comercio o industrias $y$, en general, de cualquier actividad de la producción o de los servicios". existencias de mercaderías, materias primas, grupos de bienes de una misma clase, inventarios, productos elaborados o semielaborados y repuestos del comercio o industria y, en general, de cualquier actividad de la producción o de los servicios $[\ldots]$ "..
Ley No 20.190, artículo 11 inciso $1^{\circ}$
"En el caso de prendarse grupos de bienes de una misma clase o universalidades de hecho,

tales como existencias, inventarios, materias primas, productos elaborados o semielaborados o repuestos, o maquinarias, redes o sistemas [...]".

Nos interesan los textos paralelos de la última fila.

En todos los textos, hay cierta enumeración empírica y ejemplar, que en el artículo 6 de la Ley No 18.112 y en el artículo 15 del proyecto del

${ }^{13}$ Para los efectos del punto que aquí tratamos, vale decir, del relativo al objeto de la pignoración, la evolución textual intermedia del proyecto en las Cámaras no interesa. Sólo dejamos constancia que el texto de la disposición finalmente aprobado y promulgado emanó de una indicación sustitutiva del Ejecutivo, presentada en la Comisión de Hacienda del Senado, con ocasión del segundo informe que debía evacuar esta Comisión: véase Historia, pp. 1.321-1.322 y 1.325-1.326.

${ }^{14}$ Cámara de Diputados, Legislatura 349a, Ordinaria, sesión $14^{\mathrm{a}}$, de 8 de julio de 2003, en Historia, p. 71. 
"Mensaje" se cierra con una descripción general, mientras que en el artículo 11 de Ley de prenda sin desplazamiento la enumeración sigue a una descripción general con que se abre.

En el artículo 6 de la Ley No 18.112, esa enumeración se descompone así:

existencias de

mercaderías

materias primas

productos elaborados

[productos] semielaborados

repuestos del comercio

[repuestos] de las industrias

(en general) de cualquier actividad de la producción o de los servicios

La norma, pues, autoriza la prenda únicamente sobre "existencias". La enumeración que enseguida ofrece corresponde a algunos tipos de tales (de mercaderías, de materias primas, etcétera), que es clausurada con la dicción general de existencias (se subentiende que provenientes) de cualquier actividad de la producción o de los servicios, aunque aquí se echa en falta "del comercio".

Algo semejante acaece en el artículo 5 inciso $7^{\circ}$ del "Mensaje", que conviene volver a comparar con la enumeración de existencias ofrecida por el artículo 6 inciso $1^{\circ}$ de la Ley No 18.112:

Ley 18.112 , artículo 6 inciso $1^{\circ}$

\section{"Mensaje", artículo 5 incisos $7^{\circ}$}

"Puede constituirse prenda sin desplazamiento sobre

$$
\begin{aligned}
& \text { existencias de } \\
& \text { mercaderías } \\
& \text { materias primas }
\end{aligned}
$$

productos elaborados [productos] semielaborados repuestos del comercio [repuestos] de las industrias (en general) de cualquier actividad de la producción o de los servicios"
"A menos que las partes acuerden lo contrario, en el caso de existencias de

mercaderías
materias primas
grupos de bienes de la misma
clase
inventarios
productos elaborados
[productos] semielaborados
repuestos del comercio
[repuestos] de la industria
(en general) de cualquier acti-
vidad de la producción o de
los servicios"

También en el "Mensaje", pues, el concepto de "existencias" es el básico y la enumeración que ahí se contiene no es de objetos pignorables distintos, sino de tipos precisamente de existencias; aunque, como se ve, contiene un par de rubros adicionales: los "grupos de bienes de la misma clase" y los "inventarios". 
El artículo 11 inciso $1^{\circ}$ de la Ley de prenda sin desplazamiento cambió ostensiblemente la estructura de la fórmula empleada en sus antecedentes. Mas, para apreciar el cambio es conveniente exponer preliminarmente el paralelo descompuesto:

"Mensaje", artículo 5 inciso 7º

"A menos que las partes acuerden lo contrario, en el caso de

existencias de

1. mercaderías

2. materias primas

3. grupos de bienes de una misma clase

4. inventarios

5. productos elaborados

6. (productos) semielaborados

7. repuestos del comercio

8. [repuestos] de la industria

9. (en general) [existencias] de cualquier actividad de la producción o de los servicios
Ley No 20.190 , artículo 11 inciso $1^{\circ}$

"En el caso de prendarse grupos de bienes de una misma clase o universalidades de hecho, tales como

1. existencias

Para el artículo 6 inciso $1^{\circ}$ de la Ley No 18.112 y el artículo 5 inciso

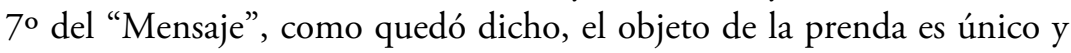
unitario, y consiste en aquello que viene denominado con la expresión "existencias", de que se ofrece una cierta variedad de tipos, cerrados con una formulación general, pero siempre referida a "existencias", pues se trata de existencias provenientes de cualquier actividad de la producción o de los servicios. Para el artículo 11 inciso $1^{\circ}$ de la ley, en cambio, los objetos de la prenda son dos: grupos de bienes de una misma clase o universalidades de hecho; y los casos que el "Mensaje" consideraba tipos de "existencias", son ahora tipos de tales grupos o universalidades, incluyendo las existencias mismas, más otros ańadidos; vale decir, antes se trataba de "existencias de" materias primas, de "existencias de" inventarios, de "existencias de" productos elaborados o semielaborados, de "existencias de" repuestos de la industria y del comercio; y ahora se trata de existencias, como tipo autónomo y separado, al que le siguen, también como tipos autónomos y separados del anterior, los inventarios, las materias primas, los productos 
elaborados o semielaborados, los repuestos; todos las cuales son tipos particulares de la noción general "grupos de bienes de una misma clase" o "universalidades de hecho".

En el resto, en la ley quedó eliminada la anterior referencia general a "cualquier actividad de la producción o de los servicios". También se observará que uno de los tipos de existencias en el "Mensaje", vale decir, las de "grupos de bienes de una misma clase", en la ley pasó a ser uno de los tipos generales junto al de las "universalidades de hecho". Las existencias de "repuestos del comercio o industria" pasaron a ser simplemente "repuestos"; se añadieron las "maquinarias", las "redes" y los "sistemas"; y se eliminó una mención expresa a las "mercaderías".

La diversa manera de ordenar los rubros nos ayudará en la interpretación de la norma.

\section{LA NOCIÓN DE “GRUPOS DE BIENES DE UNA MISMA CLASE O UNIVERSALIDADES DE HECHO”}

De la precedente explicación fluye que, en la economía del artículo 11 de la ley, se trata de una prenda sin desplazamiento, no ya sobre "existencias", sino sobre grupos de bienes de una misma clase o universalidades de hecho. Cumple ahora examinar estas nociones.

1. Como acabamos de ver, la dicción "grupos de bienes de una misma clase" aparecía en el texto originalmente propuesto por el Ejecutivo a la Cámara de Diputados, para designar un tipo de existencia, precisamente de tales grupos. En la ley ya no se trata de que la prenda recaiga sobre existencias de grupos de bienes de una misma clase, sino que recaiga directamente sobre tales grupos, con independencia absoluta de la noción de existencia.

a) La expresión "grupos de bienes de una misma clase" no es técnica del Derecho, aunque incluye un concepto técnico de éste, como es el de "bien"; en el resto, debemos estar al uso común del hablar.

La palabra "grupo" pertenece al mismo campo semántico de otras tantas como "conjunto, colección, cúmulo o acumulación, masa, acervo, acopio" y otras, denotadoras, pues, de una multitud o muchedumbre de bienes (en este caso), que no se encuentran inconexos entre sí, o esparcidamente separados ni difundidos, diseminados o desperdigados, sino, precisamente agrupado. Pero, como veremos mejor más adelante, no se trata de que los bienes de la misma clase que han de ser pignorados hagan parte de un grupo real previo, como si se dijera, por ejemplo, que ellos han de estar de antemano acumulados en un mismo lugar, o que forman un cierto ensamblaje físico o ideal mutuo. Cuando la ley emplea la palabra "grupo" quiso denotar su autorización en orden a pignorar muchos bienes 
al menos agrupados para efectos de la pignoración, aunque previamente no formen grupo alguno. Lo sustantivo es, pues, que se trata de muchos bienes considerados en conjunto o cúmulo al ser pignorados, aunque antes del acto no hayan formado grupo alguno. Lo cual no implica, por cierto, que un conjunto real de bienes no pueda formar un grupo ni pueda pignorárselo.

b) La voz "bienes", aunque no esté definida, significa el patrimonio o haber de una persona ${ }^{15}$, cuya composición es de cosas corporales e incorporales, como lo dice el artículo 565 inciso $1^{\circ} \mathrm{CC}$. En el contexto prendario a que pertenece el artículo 11, el uso de la voz "bienes", y no de aquélla de "cosas" se justifica porque, no bien la prenda sin desplazamiento de cosa ajena valga (artículo 13 inciso $2^{\circ}$ de la ley) ${ }^{16}$, ella no puede prevalecer finalmente contra el verdadero dueño. Para que la prenda resulte absolutamente inatacable, pues, debe provenir del dueño, vale decir, recaer sobre un bien y no meramente sobre una cosa.

Pero el empleo de esta palabra aclara una consecuencia importante: como los bienes consisten en cosas corporales e incorporales (artículo 565 inciso $1^{\circ} \mathrm{CC}$.), una prenda sin desplazamiento puede recaer no sólo sobre grupos de cosas corporales, mas también sobre grupos de cosas incorporales (en ambos casos, de una misma clase ${ }^{17}$ ). Así, por ejemplo, en el orden de los derechos personales, se puede pignorar, merced al artículo 11, una cartera crediticia por cierta institución de crédito; o de derechos derivados de contratos de seguros por alguna compañía de tales; o de derechos derivados de contratos de edición por una empresa editorial; etcétera. En el orden de los derechos reales, se puede pignorar, por ejemplo, un conjunto de derechos muebles de aprovechamiento de aguas ${ }^{18}$.

c) La ley habla, empero, de "bienes de la misma clase". Preliminarmente advirtamos que esto no significa que esté prohibida la pignoración de bienes

${ }^{15}$ Sobre el punto, véase: GuzMán BRITO, Alejandro, Las cosas incorporales en la doctrina y en el Derecho positivo (2a edición, Santiago, Editorial Jurídica de Chile, 2006), pp. 49-52.

${ }^{16}$ Acerca de este tema, véase: GuZMÁn BRITo, Alejandro, Las prendas ordinaria y sin desplazamiento de la Ley $N^{\circ} 20.190$, recaidas en cosa ajena, en el libro-homenaje que la Universidad Diego Portales dedicará al profesor Christian Larroumet (en prensa).

${ }^{17}$ Por lo demás, en materia de prenda sin desplazamiento, la pignoración de cosas incorporales, o sea, de derecho personales y reales, está expresamente permitida (artículos 1 y 5); y no hay razón para impedir que se pueda pignorarlas por grupos.

${ }^{18}$ Vale decir, cuando las aguas sobre que recae el derecho no están destinadas al uso, cultivo o beneficio de un inmueble, porque en tal caso son por su naturaleza muebles dichas aguas (artículo 4 CA.) y, consiguientemente, también el derecho de aprovechamiento que en ellas recae (artículo 580 CC.) 
de distintas clases. Nada en la letra ni en el sentido de la ley, determinado por su razón o espíritu, puede conducir a semejante conclusión. La dicción legal, por consiguiente, sólo significa que el estatuto establecido por el artículo 11 es aplicable si los bienes agrupados y pignorados son de la misma clase. Cuando lo fueren de distintas clases, la prenda vale y es eficaz, pero no se rige por el estatuto aplicable a bienes de una misma clase según ese artículo. Podemos adelantar que, empero, eso no impide que resulten sujetos al mismo estatuto si caen bajo el concepto de universalidad de hecho.

De todos modos, la cualidad de pertenecer a una misma clase un grupo de bienes es relativa, pues depende del punto de vista que se adopte para aprehenderlos. Por cierto, una colección de sellos de correo es un grupo de bienes de la misma clase, cuando se atiende al género "sellos de correo" para aprehenderlos; pero dejan de serlo cuando se atiende al género "sellos de correo chilenos", si es que en la dicha colección hay sellos de diferentes países. Las mercaderías existentes en un supermercado son bienes de muy diferentes clases, como la experiencia enseńa, sobre todo al observar la práctica moderna de este negocio, que ofrece alimentos, electrodomésticos, plantas de ornamentación, materiales para la construcción y muchas otras cosas de tan diversa clase. Estos ejemplos ponen en aparente crisis la cualidad exigida por la ley, en orden a pertenecer a una misma clase los bienes que forman un grupo para hacerles aplicable el estatuto del artículo 11 bajo ese concepto. Pero en el fondo la exigencia no hace más que velar por la correcta identificación del contenido del grupo pignorado y es aplicación del artículo 1461 CC., si interpretamos que "misma clase" en el artículo 11 significa "su género" próximo mentado en aquél. Cuando el dueño de un establecimiento de comercio, por ejemplo, de un supermercado, que debe conferir prenda de sus mercaderías a la venta, la confiriera sobre un único grupo identificado como "mercaderías", eso fuere, pues, en contravención con los artículos 1461 CC. y 11 de la ley.

Comoquiera, pues, que los bienes que se desea pignorar como conjunto se muestren reluctantes a ser adscritos a una misma clase en el sentido de pertenecer a un mismo género próximo, entonces debe procederse a formar tantos grupos cuantas clases o géneros próximos sean posibles, como, en el caso del supermercado, el de tales frutos enlatados o en conserva, o de los "piscos", o de los vinos tintos de tal marca y clase, o el de las bebidas gaseosas tales y cuales, etcétera.; y enseguida hacer recaer el gravamen sobre todos y cada uno de estos grupos, merced, por cierto, a un único contrato prendario. No hay, así, real obstáculo para que la prenda se haga recaer sobre conjuntos de bienes que en sí mismos son de distintas clases, si previamente se los desglosa en grupos de bienes de una misma clase. 
2. La noción de "universalidad de hecho" es, en cambio, técnica. Como es sabido, ella proviene del Derecho romano ${ }^{19}$, aunque el nombre sea medieval (universitas facti).

a) Por tal, se entiende una pluralidad -dos al menos, sin máximo-de cosas muebles en el caso de nuestra prenda, cada una materialmente autónoma con respecto a la otra ${ }^{20}$, pero destinadas todas a un fin o función unitarios por su dueño, que por ello son idealmente miradas como unidad y consideradas bajo un nombre común ${ }^{21}$. Son, pues, universalidad de hecho conjuntos como un rebaño (ganado, piara, hato, recua, tropel, etcétera), una colección de monedas o de sellos de correo, una biblioteca, el ajuar o moblaje de una casa, las existencias de mercaderías de un establecimiento comercial, las existencias de materias primas de una empresa fabril, una nave mayor, etcétera. Se observará que en el concepto no ingresa la exigencia de ser de la misma clase los bienes que conforman cierta universalidad de hecho, como ocurre en una nave, cuyos componentes, en cuanto universalidad de hecho, incluyen cosas tan disímiles como el casco, los aparejos y los fletes. En compensación, sí ingresa en él la idea de destinación unitaria del conjunto a un fin o función.

b) Por ello conviene determinar la relación existente entre las nociones de "grupo de bienes" (dejemos, por ahora, a un lado el añadido de tratarse de "bienes de una misma clase") y "universalidad de hecho". Toda universalidad de hecho es, por definición, un grupo de bienes, pero real y objetivo, que existe en cuanto grupo con anterioridad a cualquier acto jurídico que haya de recaerles. La relación que en principio podemos establecer entre ambas nociones es ésta: toda universalidad de hecho es un grupo real de bienes, pero no todo grupo real de bienes es una universalidad de hecho. Así, el cúmulo de objetos depositados azarosa y paulatinamente en la bodega de una casa, puede ser considerado un grupo real de bienes, pero no una universalidad de hecho. El grupo real deviene en universalidad cuando su dueño le asigna un fin o una función común.

3. La dicción legal ofrece un problema si se mirare a las nociones de

${ }^{19}$ Véase: Bonfante, Pietro, La formazione scolastica della dottrina dell' "universitas” (1906), después en El MIsmo, Scritti giuridici vari (Torino, UTET., 1926), I, pp. 307-323; BIONDI, Biondo, La dottrina giuridica della 'universitas' nelle fonti romane, en Bulletino dell'Istituto di Diritto Romano 61 (Roma, 1958), pp. 1-59; Dell'Oro, Aldo, Le cose colletive nel Diritto romano (Milano, Giuffré, 1963).

${ }^{20}$ No se trata, pues, de varias cosas unidas realmente, como las que conforman un reloj,

${ }^{21}$ Para el concepto de universalidad de hecho, véase, por todos: Biondi, Biondo, Los bienes (1956, traducción castellana, Barcelona, Bosh, s. d. [pero 1961]), pp. 157-170. 
"grupo de bienes de una misa clase" y "universalidad de hecho" como sinónimos, porque, como hemos visto, no lo son. Lo propio ocurre si se las mirare en mutua interacción, como cuando se dijere que el objeto pignorable está constituido por "grupos de bienes de la misma clase que sean universalidad de hecho", lo cual equivaldría a exigir universalidades de hecho compuestas por cosas de la misma clases, lo que sí es posible, como en una colección de sellos de correo, o en una biblioteca; pero que restringiría el ámbito de la ley cuando no hubiera coincidencia. Así que la aparentemente única interpretación aceptable es que se pide, ora grupos de bienes de la misma clase, ora universalidades de hecho, aunque ambos cúmulos no coincidan y no bien a veces sí coincidan. De acuerdo con ello, se puede pignorar, según el artículo 11, tanto un conjunto constituido por objetos antiguos en colección, que es una universalidad de hecho, aunque no un grupo de cosas de la misma clase, supuesto que en ella haya muebles, cristales, lámparas y otros objetos diversos, como la chatarra de un establecimiento fabril, que es un grupo de cosas de la misma clase (chatarra), pero no cierta universalidad de hecho, lo mismo, en fin, que un rebaño de ovejas, que al tiempo es una universalidad de hecho y un grupo de cosas de la misma clase.

Pero esta aparentemente posible interpretación, con permitir superar un problema, introduce al tiempo uno nuevo. El concepto de universalidad de hecho es una muy correcta opción dogmática de la ley, que explica adecuadamente el funcionamiento de la pignoración regulada por su artículo 11. Debemos dejar constancia que el recurso a esa noción parece ser una novedad en el Derecho comparado de la prenda sin desplazamiento, porque las legislaciones, no bien suelan atribuirle el mismo régimen previsto en el artículo 11, no ofrecen una base dogmática que lo explique. Con el recurso al concepto de universalidad de hecho, en cambio, la ley chilena se asienta en un terreno seguro. Acerca de esto hablaremos al estudiar el régimen fijado por el artículo 11.

Ahora bien, si, como vimos, son distintas las nociones de "grupo de bienes de una misma clase" y de "universalidad de hecho", eso rompe la doctrina dogmática en que se funda aquel artículo, pues queda sin justificación el régimen de la prenda de tales grupos cuando no sean universalidades.

Sin embargo, la imposición de unidad conceptual es posible, merced al siguiente razonamiento. Cuando el dueño de ciertos bienes de una misma clase los agrupa a efectos de constituir una prenda sobre ellos, con esa misma operación lo que también hace es crear una universalidad de hecho, porque entonces empiezan a coincidir los elementos que la conforman. El conjunto, por más que sea convencional, vale decir, configurado para su 
pignoración, aunque antes no haya sido real y objetivo, ahora empieza a serlo, y con ello ya se cumple con la primera exigencia en toda universalidad. Enseguida, a este grupo ahora real le viene impuesta una finalidad o función, como es precisamente la de su pignoración, y entonces se cumple con la segunda exigencia de la universalidad de que hablamos. Y de esta manera la formación del grupo de bienes de una misma clase para su pignoración implica la articulación de la universalidad que buscamos. Esto significa que los "grupos de bienes de una misma clase" mentados en el artículo 11 son asimismo universalidades de hecho, sólo que construidas en el proceso de la pignoración, por así decirlo, y en función de ella, a diferencia de las universalidades de hecho mencionadas enseguida por el texto legal, que son previas, porque deben ser reales y objetivas en su base material y en su función, independientemente de su actual superpuesta destinación al gravamen. Esta diferencia explica la mención literaria aparte. Así que la expresión completa hay que entenderla como si se hubiera escrito: "En el caso de prendarse universalidades de hecho, incluidas las que consistan en grupos de bienes de una misma clase constituidos para su pignoración $[\ldots] "$

\section{ACTOS JURÍDICOS SOBRE GRUPOS DE BIENES O UNIVERSALIDADES DE HECHO Y ACTOS JURÍDICOS SOBRE CADA UNO DE LOS COMPONENTES DE UN GRUPO DE BIENES O UNIVERSALIDADES DE HECHO}

1. Una de las propiedades ofrecidas por las universalidades de hecho, que constituye otra de sus varias utilidades, es la aptitud para reducir una multitud a unidad, y tratar a sus componentes no como muchos individuos, más como uno sólo. Supóngase una biblioteca. Su dueño, que desea enajenar los libros, puede optar entre varias alternativas. Puede vender singularmente cada libro a tal precio. Puede vender todos los libros, pero singularizados en un inventario, a tal precio, diferenciado o al mismo, por unidad, lo que da un total único para el conjunto, bien por suma de los distintos precios, bien por multiplicación del precio único por el número de unidades. También puede vender la biblioteca por un precio alzado (aunque en privado, para fijar tal precio, haya previamente valorizado cada unidad). En los dos primeros casos se trata de la compraventa normal de varias cosas, y da lo mismo si son dos o tres o bien muchas. En el tercer caso se trata de la venta de una única cosa: de la biblioteca considerada como universalidad, aunque ésta contiene una multitud de libros.

La pignoración de que trata el artículo 11, pues, obedece a la tercera alternativa del ejemplo anterior: se trata de la pignoración de grupos o universalidades, no de sus componentes individuales o singulares. Lo cual 
no significa que no se puedan pignorar sin desplazamiento los componentes individuales o singulares de un grupo o de una universalidad. Sólo que, en tal caso, la pignoración no se rige por el artículo 11 .

Ilustremos la diferencia con un ejemplo: supongamos que hay un rebaño de ovejas "karakul", cuyas cabezas están todas marcadas al fuego con un cierto signo distintivo común, seguido de un número propio. Eso implica la posibilidad de individualizar a cada oveja: $\mathrm{X}_{1}, \mathrm{X}_{2}, \mathrm{X}_{3} \ldots$ $\mathrm{X}_{\mathrm{n}}$. En total son $500(=\mathrm{n})$. El dueño de este rebaño puede optar por pignorar sin desplazamiento las ovejas desde la $\mathrm{X}_{1}$ a la $\mathrm{X}_{500}$, y se trata de la pignoración de cada oveja singular en un solo acto. Por consiguiente, la desaparición de algunas cabezas, debida, por ejemplo, a su muerte natural, extingue la prenda sobre esa cabeza (artículo 2406 CC.) y se perjudica el pignoratario; las crías nacidas no quedan pignoradas y deben ser restituidas inmediatamente al pignorante, salvo en el caso del artículo 2403 CC.; el pignorante, a su vez, no puede disponer de las ovejas, ni siquiera con reemplazo (artículo 2395 CC.), salvo que lo autorice el pignorante, etcétera. Otra cosa es cuando se pignora el rebaño de ovejas "karakul", todas adultas, que se mantiene en el potrero No 5 del fundo tal y que, a la fecha del contrato, se compone de 500 cabezas. Ahora los aumentos y detrimentos del rebaño no lo afectan como tal ni, por ende, a la prenda. Así que si aquel experimenta aumentos por las crías, éstas, como forman parte del rebaño, se ven cubiertas por su prenda; y si sufre disminuciones, por muertes naturales, no hay cuestión de extinción de la prenda. Si el pignorante añade cabezas al rebaño, ocurre lo mismo que en el caso de las crías; y puede disponer de las cabezas, con la misma indiferencia para la prenda que en el caso de las muertes naturales. Cosa distinta es, por supuesto, el cambio del valor de la universalidad pignorada, derivado de los aumentos o detrimentos que sufra su composición. Al incrementarse el rebaño con crías, ello acrecienta su valor; el detraerse por muertes, lo aminora $^{22}$. Este es otro problema. Por lo que atañe al rebaño, empero, él sigue siendo el mismo, mientras haya al menos dos ovejas.

${ }^{22}$ El Código Civil conoce la diferencia entre universalidad y especificación de muchas cosas, aunque sean todas, si bien para neutralizar o prohibir ciertos actos sobre universalidades. Así, el artículo 1407 CC. da por sentado que se puede hacer donación a título universal, vale decir, de la universalidad del patrimonio de una persona, pero exige un inventario solemne de los bienes donados. En consecuencia, la donación se extiende sólo a los bienes que aparezcan en el inventario y no a más. La donación universal es, pues, completamente neutralizada y convertida en una de muchos bienes uno a uno en un solo acto. El artículo 1811 CC., bajo el lenguaje de "venta de todos los bienes presentes of futuros, o de unos y otros", sanciona con nulidad la venta universal; si bien declara válida la de "todas las especies, géneros y cantidades que se designen por escritura pública", aunque abarquen, de hecho, todo lo que el 
Por consiguiente, la pignoración de un grupo o de una universalidad exige que no se especifiquen los individuos componentes. Ejecutada una operación así, la pignoración deja de ser prenda de grupos o universalidades, y se convierte en la pignoración de varias o muchas cosas, una a una, en un solo acto, y la figura hay que mirarla como si hubiera tantas prendas cuantas cosas, a salvo el principio de indivisibilidad.

2. $\mathrm{Si}$, como acabamos de ver, los actos jurídicos recayentes en cierta universalidad de hecho tienen por objeto a la universalidad misma y no a cada uno de sus componentes singularmente considerados, para dar cumplimiento al artículo 1461 CC. sólo necesitan determinar el género (próximo) y la cantidad de la universalidad misma, no de cada uno de dichos componentes; y las consecuencias del acto de que se trate, incidiendo sobre la universalidad, afectan a los componentes que se demuestren ser tales en el momento en que haya de aplicarse la consecuencia respectiva. $\mathrm{Si}$, por ejemplo, se vende un rebaño, la entrega del rebaño vendido comprenderá, no las cabezas que lo componían en el momento de la venta, sino las que lo componen en el momento de la entrega, que suelen diferir, porque en el tiempo intermedio pudieron morir algunas cabezas y nacer otras; y teóricamente hasta puede acaecer que todas las cabezas iniciales ya no existan y que las actualmente existentes sean distintas; pero el rebaño es el mismo. Esto porque las universalidades de hecho siguen siendo las mismas pese a la mudanza de sus componentes. Como veremos, la ley aplica esta propiedad de las universalidades de hecho, incluso a los grupos de bienes de una misma clases, lo que es posible porque, como vimos, al ser pignorados, empiezan a ser ellos mismos tales universalidades.

3. Estas propiedades de las universalidades de hecho fueron advertidas por los juristas romanos en tema de pignoración. En las fuentes, en efecto, aparece muy clara la idea, desde luego, de poderse pignorar el conjunto constituido por un establecimiento comercial (taberna), sus implemento y sus mercaderías; subsiguientemente, que en tal caso está permitido vender las mercaderías sin perjuicio de la prenda, que afecta a las ingresadas ulteriormente para reponer la existencia que permite mantener el giro; $y$, en fin, que el contenido del conjunto queda fijado en un cierto momento, que en el texto que citamos es ocasionalmente el de la muerte del deudor ${ }^{23}$.

vendedor tenga, incluso de cosas que espera adquirir; pero el acto alcanza sólo a lo especificado en la escritura. El artículo 2056 CC. prohíbe la sociedad a título universal; pero admite la de muchos bienes (que pueden ser todos los que actualmente tenga el socio), siempre que se especifiquen.

${ }^{23}$ Dig. 20, 1, 34 pr. (Scaev., 27 dig.): "Como un deudor hubiera dado en prenda cierto bazar a un acreedor, se preguntó si por ese hecho nada se hizo [sc. si es nulo el acto] o si se considera que bajo la denominación de 'bazar' hayan quedado obliga- 
La idea de que, merced a un pacto, la prenda de un conjunto cubre a las cosas fabricadas con componentes de ese conjunto también es romana ${ }^{24}$. Así que los extremos fundamentales del modelo de la prenda prevista por el artículo 11, o sea, de la "floating charge", que suele ser presentada como una novedad del Derecho inglés ${ }^{25}$, en realidad ya estaban presentes en el Derecho romano, que pudo llegar a ella gracias al concepto de universalidad de hecho.

\section{TIPOS ESPECÍFICOS DE GRUPOS DE BIENES DE LA MISMA CLASE Y DE UNIVERSALIDADES DE HECHO ENUMERADOS COMO EJEMPLOS POR EL ARTÍCULO 11}

El artículo 11, después de emitir la fórmula general que acabamos de examinar, ofrece ejemplos, aunque no tipos taxativos.

das las mercaderías que en él hubiera habido. Y si, por intervalos, tales mercaderías hubieran sido vendidas y se hubiera comprado otras e incorporado en la taberna y haya fallecido [sc. el dueño del bazar], acaso el acreedor pudo pedir con la acción hipotecaria todas las cosas que ahí se hubieran encontrado, comoquiera que no sólo hayan cambiado las formas de las mercaderías mas también se hayan introducidas otras cosas. Respondió: aquellas cosas que fueron encontradas en la taberna al momento de la muerte del deudor parecen obligadas por la prenda" ("Cum tabernam debitor creditori pignori dederit, quaesitum est, utrum eo facto nibil egerit an tabernae appellatione merces, quae in ea erant, obligasse videatur? Et si eas merces per tempora distraxerit et alias comparaverit easque in eam tabernam intulerit et decesserit, an omnia quae ibi deprehenduntur creditor hypothecaria actione petere possit, cum et mercium species mutatae sint et res aliae illatae? respondit: ea, quae mortis tempore debitoris in taberna inventa sunt, pignori obligata esse videntur"). La misma idea en Dig. 20, 113 pr. (Marc., l. sing. ad form. hypoth.): "Habiéndose obligado en prenda un rebańo, quedan obligadas las crías que nazcan después; pero si, habiendo muerto las primitivas cabezas, todo el rebaño fuese renovado, también estará obligado por la prenda" ("Grege pignori obligato quae postea nascuntur tenentur; sed et si prioribus capitibus decedentibus totus grex fuerit renovatus, pignori tenebitur"). Sobre ambos textos: MeNTXACA, Rosa, La pignoración de colectividades en el Derecho romano clásico (s. 1. [pero Bilbao], Servicio Editorial de la Universidad del País Vasco, s. d. [pero 1986]), pp. 207-214 y 221-225.

${ }^{24}$ Dig. 13, 7, 18, 3 (Paul., 29 ed.): "Si alguien hubiese pactado que se le diese en prenda un bosque, dice Casio que la nave fabricada con la madera proveniente de él no queda en prenda, porque una cosa es la madera y otra el bosque; y por ello dice que se ha de añadir expresamente al dar la prenda: 'y cualquier cosa que haya sido hecha o nacida del bosque" ("Si quis caverit, ut silva sibi pignori esset, navem ex ea materia factam non esse pignori Cassius ait, quia aliud sit materia, aliud navis; et ideo nominatim in dando pignore adiciendum esse ait: 'quaeque ex silva facta natave sint'”). Sobre el texto: Mentxaca, R., Pignoración de colectividades, cit. (n. 11), pp. 217-221.

${ }^{25}$ Véase la nota 5. 
a) En primer lugar vienen mencionadas las "existencias". Este término es de uso común en el habla de los industriales y comerciantes y de la Contabilidad y las Finanzas. El Diccionario de la lengua española de la Real Academia Española le atribuye esta acepción cuarta: "Mercancía destinada a la venta, guardada en un almacén o tienda". Ella equivale a la palabra inglesa "stock (on hand)", que por su frecuente uso en castellano, el mismo Diccionario se ha sentido forzado a definir como: "Cantidad de mercancías que se tienen en depósito", aunque no añade ahora la nota de "estar destinadas a la venta", que en realidad va subentendida, puesto que de mercancías se trata. Una definición más detallada y amplia encontramos en un acreditado diccionario especializado: "Existencias ('Inventory', 'Stock on hand', 'Existenz'): Conjunto de bienes, artículos, materias primas, productos en proceso de elaboración u otros que conservan las empresas a fin de asegurar la producción y para la normal distribución a sus clientes. Cosas, especialmente mercaderías, que non han tenido aún la salida o empleo a que están destinadas. Inventario" ${ }^{26}$. Las existencias pueden ser de varias clases: "El nombre específico con que se denomine a las existencias dependerá del tipo de empresa y de su actividad, también de la persona que defina el Plan de Cuentas de cada empresa, siendo así como encontramos comúnmente: empresa comercial (mercaderías; materiales); empresa fabril o productiva: materias primas, materiales, productos en elaboración, productos terminados; empresa de servicios: materiales, suministros, trabajos en curso" 27 .

La palabra "existencias" denota, pues, un conjunto real de cosas corporales muebles, que "existen"; pero no en pertenencia a cualquier persona, sino a un establecimiento, cuando se trata de aquellos elementos corporales acumulados y destinados a la elaboración intermedia o final de un producto en serie para ser expendido a los distribuidores, en el caso de un establecimiento fabril; o a la distribución a los minoristas o consumidores, en el caso de un establecimiento comercial; o como complementos al giro principal o instrumentos para él, cuando lo es de servicios. Así, en el caso de una fábrica, se trata de las materias primas principales y accesorias, de las partes y piezas, de los productos semielaborados o en proceso de fabricación y de los productos finales o elaborados. Si consideramos una empresa que elabora cigarrillos, sus existencias serán, pues, las hojas de tabaco en bruto, las sustancias químicas usadas en el proceso de fabricación, el papel para cigarrillos y para su envase y las tintas de impresión, o bien, los pliegos

${ }^{26}$ Álvarez Osben, Alberto, Diccionario de términos contables, comerciales y computacionales (Valparaíso, Ediciones Universitarias de Valparaíso, 1987), p. 214.

${ }^{27}$ Silva Palavecinos, Berta, Fundamentos del sistema contable: nuevos enfoques $y$ actualización (Valparaíso, Ediciones Universitarias de Valparaíso, 2006), p. 257. 
ya impresos, si se fabrican en otro establecimiento, también el tabaco ya tratado y cortado y los cigarrillos ya formados pero aun no envasados, en fin, las cajetillas de cigarrillos y, por último, los paquetes de un número determinado y constante de cajetillas. Estos paquetes constituyen, por su lado, las existencias de cualquier establecimiento comercial distribuidor de cigarrillos al menudeo. Pero también lo son de un establecimiento de servicios turísticos, que no vende cigarrillos, pero los ofrece como obsequio a sus clientes mientras esperan su turno para ser atendidos. En cambio, el ajuar o moblaje de una casa particular, aunque es también un conjunto de cosas corporales muebles que existen en esa casa, no se dice que son una "existencia" de su dueño. Tampoco el contenido de una bien provista despensa se dice ser una "existencia" de su dueño. En general, de los particulares no se dice que tengan, pues, "existencias".

El recurso a este concepto nuevamente pone en aparente crisis la dicción legal de deber tratarse de una "misma clase" el grupo de bienes pignorable, porque las existencias pueden ser de bienes de igual o de diferente clases, como acontece en una empresa fabril de diversificado giro o en un establecimiento de comercio o de servicios variados. Y nuevamente, pues, para dar sentido genuino a una descripción literal como "grupos de bienes de una misma clase [...], tales como existencias", y no limitar las existencias pignorables a las integradas por cosas de una misma clases, necesario es reiterar la necesidad de clasificarlas por sus géneros o clases homogéneos, para formar diversos grupos, cada uno con bienes de un mismo género o clase, y pignorarlos en un solo acto, o bien, si se quiere, en actos separados. Pero las existencias, aun antes de su pignoración, son típicamente una universalidad de hecho, fin unificador del cual conjunto es la fabricación y venta, tratándose de los establecimientos fabriles, de la venta, cuando se trata de los comerciales o del apoyo en el caso de los servicios. Pero pueden ser de diversas clases. Por cierto, nada obsta a que se distingan diversas universalidades de hecho, precisamente por las clases de las cosas componentes.

De la discusión precedente brota que el término en examen no suele aplicarse a las cosas incorporales. De la cartera de créditos de un banco, en efecto, no se dice tratarse de su "existencia" de créditos.

b) Se mencionan enseguida los "inventarios". La palabra puede denotar: i) una operación; ii) un documento; y iii) un conjunto de cosas corporales o incorporales. La primera acepción también queda significada por el verbo "inventariar" y en final de cuentas alude a la actividad de individualizar físicamente cada una de las cosas que se hallan ("inventan") en cierto conjunto predefinido y de registrarlas de acuerdo con algunos puntos de vista preestablecidos, como pueden ser sus características pro- 
pias, su nombre, su marca, su código, su localización, su número, peso o medida, etcétera. La operación puede comprender o no una valorización de cada elemento singular inventariado. Ahora bien, los resultados de la operación de inventariar suelen quedar anotados en un documento, que también recibe el nombre de inventario, y es la segunda acepción antes enumerada. En fin, las cosas inventariadas y registradas en el documento, por metátesis de continente a contenido, se llaman también "inventario", y ahora se trata de la tercera acepción. De esta manera, se puede decir: i) presenciar el inventario o asistir a él o participar en él, y ahí se alude a la operación; ii) protocolizar, guardar o destruir el inventario, y entonces se alude al documento; y iii) vender el inventario, y ahora se alude a las cosas descritas y relacionadas en el documento.

La palabra "inventario" pertenece al uso común del habla de los industriales y comerciantes y es técnica en el lenguaje de la Contabilidad y las Finanzas, en su tercer sentido, para denotar las cosas corporales e incorporales pertenecientes a un establecimiento fabril, comercial o de servicios, que por ley, costumbre, preconvención o convención deben ser objeto periódico de la operación de inventariar cuyos resultados, por cierto, quedan registrados en documentos. Así la define el diccionario que antes citamos: "Inventario ('Inventory', 'Bestandaufnahme'): Especificación valorada de todos los bienes, créditos y derechos a favor de una persona natural o jurídica, corporación o Estado, por un parte, y la relación -también valorada- de todas las deudas y obligaciones que pesan sobre la misma, a favor de terceros o de los propietarios" ${ }^{28}$. Más sintéticamente, lo define un autor de contabilidad legal: "Todo inventario no es sino una lista valorada de los bienes y créditos activos y pasivos del titular de una contabilidad" 29 . El artículo 29 C. de C., aunque no hable de inventario, lo mienta cuando ordena: "Al abrir su giro, todo comerciante hará en el libro de balances una enunciación estimativa de todos sus bienes, tanto muebles como inmuebles y de todos sus créditos activos y pasivos". La Norma internacional de Contabilidad No 2 lo define así: "Inventarios son activos: (a) poseidos para ser vendidos en el curso normal de la operación; (b) en proceso de producción con vistas a esa venta; $o$ (c) en forma de materiales o suministros, para ser consumidos en el proceso de producción, o en la prestación de servicios" "30; y añade que: "Entre

${ }^{28}$ Álvarez Osben, A., Diccionario, cit. (n. 15), p. 214.

${ }^{29}$ Composto Canales, Arnolfo, Manual de Contabilidad para abogados (2a edición, Santiago, Editorial Jurídica de Chile, 1996), p. 109

${ }^{30}$ Norma Internacional de Contabilidad (NIC) No 2: "Inventarios" (actualizada al 31 de diciembre de 2005), "Definiciones", 6, en Normas Internacionales de Información Financiera (NIIF) 2006 (traducción castellana autorizada, London, International Accounting Standards Board, s. d. [pero 2006]), p. 502. Estas normas son 
los inventarios también se incluyen los bienes comprados y almacenados para su reventa, entre los que se encuentran, por ejemplo, las mercaderías adquiridas por un minorista para su reventa a sus clientes, y también los terrenos $u$ otras propiedades de inversión que se tienen para ser vendidos a terceros. También son inventarios los productos terminados o en curso de fabricación mantenidos por la entidad, así como los materiales y suministros para ser usados en el proceso productivo. En el caso de un prestador de servicios, tal como se describe en el párrafo 19, los inventarios incluirán el costo de los servicios para los que la entidad aún no haya reconocido el ingreso de operación correspondiente (véase la NIC 18 Ingresos de Actividades Ordinarias) '\$1. Suelen distinguirse varios tipos de inventarios: de existencias, de productos terminados, de refacciones, en libros, final, físico, global, inicial, perpetuo, valorado ${ }^{32}$. Se mira como términos sinónimos los siguientes: "Relación, repertorio, registro, existencias. Censo, catálogo, lista estado" 33 .

Hay una conexión entre el "inventario" y las "existencias": éstas pueden o no estar en un inventario (dejemos a un lado que la ley a veces disponga que deban estarlo); el inventario puede abrazar el todo o una parte de las existencias; así que pueden coincidir o no. Cuando coinciden al comienzo, pueden dejar de coincidir después, si hubo mermas o hurtos en las existencias. Generalizando, podríamos decir que el inventario y las existencias denotan un mismo tipo de objetos reales, pero que la primera palabra los denota en cuanto realmente existen, y la segunda en cuanto fueron objetos de la operación y se encuentran registradas en un documento.

Ahora bien, el uso de la palabra "inventario" en el artículo 11 está condicionado por aludir sólo al de cosas corporales o incorporales muebles, presentes o futuras. Lo que la ley establece, pues, es que se pueden pignorar las cosas corporales o incorporales muebles, presentes o futuras, que fueron inventariadas y, por ende, se encuentran registradas en un inventario.

Pero, a diferencia de las existencias, los particulares pueden levantar un inventario. De hecho, las leyes conocen varios de ellos. Así, el Código Civil da una especial importancia al inventario en varias materias. Por un lado, su artículo 378 obliga al tutor o curador a inventariar los bienes de su pupilo en los noventa días subsiguientes al discernimiento de sus cargos; y el artículo 382 CC. describe minuciosamente el contenido de este inventario de los guardadores. Enseguida está el inventario que es preciso levantar cuando un heredero quiere o debe aceptar la herencia a él

emitidas por el Consejo de Normas Internacionales de Contabilidad (IASB).

${ }^{31}$ Norma Internacional de Contabilidad (NIC) No 2, "Definiciones", 6, ibíd., p. 502.

${ }^{32}$ Álvarez Osben, A., Diccionario, cit. (n. 15), p. 215.

${ }^{33}$ Álvarez Osben, A., Diccionario, cit. (n. 15), p. 215. 
deferida de modo de limitar su responsabilidad por las deudas hereditarias y testamentarias hasta concurrencia del valor total de los bienes que ha heredado, efecto éste que recibe el nombre de beneficio precisamente de inventario (artículo 1247 CC.). Por lo demás, el artículo 1253 CC. hace aplicable el antes citado artículo $382 \mathrm{CC}$. al modo de levantarse este inventario de bienes hereditarios. En fin, a veces las leyes exigen que para tal o cual efecto debe confeccionarse un inventario solemne, y su confección está regulada procesalmente por los artículos 858 a 865 CPC. De ellos, el artículo 861 vuelve a remitir al artículo 382 CC. en cuanto al punto de qué debe cubrir un inventario solemne.

Cierto es que en todos estos casos se trata de inventarios legalmente prescritos para diferentes efectos y no de operaciones normales, ni periódicas, como son los inventarios de las empresas. Con todo, un particular puede, cuando quiera, vale decir, aunque no esté obligado o cargado y en el momento en que escoja, levantar un inventario de sus bienes con sometimiento voluntario a ciertas formalidades, como, por ejemplo, la presencia de un ministro de fe o de testigos; y de los bienes que fueron objeto de la operación y consiguiente registro, correctamente se puede decir que son un "inventario" de ese particular. Como se comprenderá, esta conclusión permite salir del campo empresarial en el que parece pensar el artículo 11 de la ley, al campo de los particulares, quienes, por consiguiente, podrían pignorar los conjuntos de sus bienes que resultaren inventariados. Lo cual no significa que para poder pignorar conjuntos los particulares necesiten hacer inventario, como tampoco lo necesitan las empresas. Ello, en efecto, no está dicho en la ley, la cual se limita a ofrecer el inventario como ejemplo que puede ser de grupos de bienes de una misma clases o universalidades de hecho,

c) Comparecen en seguida las "materias primas", o sea, los elementos materiales de que se fabrican los objetos finales o destinados inmediatamente, sin nueva intervención, excepto el embalaje, a su distribución. Pero es claro que tales materias son parte de las existencias y de los inventarios de las empresas que se sirven de ellas para su operación.

d) Se presentan también los "productos elaborados", vale decir, los objetos finales de una operación fabril, inmediatamente destinados a la distribución. Asimismo son parte de las existencias y del inventario de las empresas que los elaboran.

e) A su lado están los "productos semielaborados", o sea, aquellos cuyas materias primas y elementos anexos han sido objeto de una primera transformación o integración en orden a convertirlos en un objeto final, sin que aún se haya éste producido, de modo de faltarles la aplicación de ulteriores procesos fabriles conducentes a la terminación. Tales productos, 
pues, constituyen un cierto estado intermedio de elaboración. Generalmente han llegado a su estado en el interior del mismo establecimiento fabril que genera el producto elaborado o final; pero pueden ser manufacturados por cierto establecimiento para ser distribuidos a otros; así que, desde el punto de vista del establecimiento que los fabrica, son finales para él; pero se siguen llamando "semielaborados" porque son función del producto final que elaborará otro establecimiento. En todo caso, es claro que tales productos también hacen parte de las existencias y de los inventarios.

f) La ley menciona, además, a los "repuestos". En general, "repuesto" es: "Toda pieza o parte destinada a la sustitución de otra similar inutilizada por el uso o la destrucción". También se denomina así a la "Pieza o parte de un mecanismo que se tiene almacenado para sustituir a otra. Recambio. Accesorios de una máquina, motor vehículo o equipo mecánico, eléctrico o de otro tipo en existencias". En este segundo sentido "constituyen siempre un elemento del activo de la empresa, en tanto se tienen en existencias; así si representan mercaderías para la venta, como si se tienen para uso propio, en previsión de desperfectos del equipo en funcionamiento" ${ }^{34}$. Estos objetos, pues, son partes o piezas fabricadas y destinadas a ser vendidas singularmente, para ser insertadas en un todo fabril mayor y final, principal, o accesorio, en reemplazo de las originales de su misma especie, que se han destruido, desgastado o perdido. Los repuestos de originales pueden ser fabricados en el mismo establecimiento que elabora el todo fabril mayor y final o en otro, aunque generalmente en conexión, como en "holding", con aquél. En todo caso, desde el punto de vista de su concepción como repuestos, en sí mismos son objetos finales, aunque funcionalmente estén destinados a ser engarzados en un cierto todo. En cualquier caso, hacen parte, igual que los anteriores objetos, de las existencias y del inventario.

g) Se mencionan también las "maquinarias" en vez de las "máquinas", y con razón, ya que aquella voz designa al conjunto de éstas, en circunstancias que el artículo 11 trata de "grupos" y "universalidades de hecho", y ambos no se conforman con la unidad.

Pero la ley no piensa en cualquier maquinaria, por ejemplo, en aquellas llamadas "relojes", o en los automóviles, sino en las máquinas fabriles o productoras, vale decir, en los artificios o artefactos, aparatos o ingenios compuestos, cuyas piezas se mueven merced a energía mecánica, eléctrica, eólica (también mecánica, en realidad), atómica o de cualquier otra clase para hacer actuar algunas de aquellas especialmente predispuestas sobre cierta materia prima y transformarla en un objeto previsto, o para coadyuvar con su transformación, embalaje o transporte, como los "robots".

${ }^{34}$ Álvarez Osben, A., Diccionario, cit. (n. 15), p. 386. 
Las maquinarias no suelen hacer parte de las existencias, pero sí del inventario.

h) El artículo 11 enumera también las "redes" y los "sistemas". Es imposible saber qué mienta específicamente la ley a través de tan genéricas palabras, por lo demás conectadas entre sí, pues toda red es un sistema, aunque no todo sistema sea una red. La imposibilidad deriva de que estas palabras fueron introducidas merced a una indicación del Ejecutivo en el proyecto $^{35}$, seguramente elaborada en el Ministerio de Hacienda y debida no se sabe a quién en concreto.

La noción de "sistema" 36 supone una pluralidad de elementos que pueden ser i) físicos, bien de naturaleza inanimada (así los que integran el sistema solar o un reloj), bien animada (tal cual un equipo de fútbol), bien de ambas clases (como una fábrica); o ii) intelectuales (como acontece con los elementos que componen las reglas de un juego o un lenguaje); o iii) físicos e intelectuales en combinación, como un concreto partido de fútbol, que es un sistema integrado por las personas que componen cada equipo y las reglas que gobiernan su actividad en el campo de deportes. Pero una pluralidad de elementos, que en sí mismo puede no ser más que un agregado de tales, empieza a ser un sistema cuando ellos comienzan a comportarse en relaciones de diversa naturaleza; así que un sistema puede ser definido como un conjunto de elementos interrelacionados. El Diccionario de que nos hemos valido en otras ocasiones ofrece esta definición: "Sistema ('System', 'System'): conjunto de reglas o principios sobre una materia enlazados entre sí. Conjunto orgánico de reglas o principios sobre una materia determinada. Conjunto de cosas que ordenadamente relacionadas entre sí contribuyen a determinado objeto" ${ }^{37}$. Por consiguiente, la especificidad de un sistema viene conferida por la idea de relación. La naturaleza, grado y modo o forma de las relaciones que unen a los elementos es tan variada, que tipologizar todo eso nos llevaría lejos, sin que sea necesario para nuestros efectos. Lo propio ocurre con la clasificación de los sistemas. Baste ofrecer ejemplos que se unan a los que acabamos de presentar al hablar de los elementos. Son, pues, sistemas el de cierto Código Civil y aun de todo un ordenamiento, hasta el punto de soler

\footnotetext{
${ }^{35}$ Véase: Historia, pp. 1.321-1.322 y 1.325-1.326.

${ }^{36}$ Literatura, entre tantos: BertalanfFy, Ludwig von, Teoría general de los sistemas. Fundamentos, desarrollo, aplicaciones (1968, traducción castellana, México, Fondo de Cultura Económica, reimpresión 1991); Gigen, John, Teoría general de sistemas (2a edición, Ciudad de México. Trillas, 1987); Johansen Bertoglio, Óscar, Introducción a la teoría general de sistemas (1991, México, Limusa-Noriega, 18a reimpresión s. d. [pero 2000]).

${ }^{37}$ Álvarez Osben, A., Diccionario, cit. (n. 15), p. 417.
} 
hablarse de "sistemas jurídicos", el sistema del átomo, una construcción, la red del alcantarillado o las redes eléctricas de una casa, de una ciudad, de un país, una empresa, un partido político, una elección presidencial o de congresales, un método de control contable o de legalidad, la policía y los ejércitos; también están el sistema bancario o el sistema financiero y el sistema monetario; y tantos otros conjunto de elementos interrelacionados como existen en la naturaleza o en la sociedad. Su estudio pertenece a una ciencia particular llamada Teoría de sistemas y el diseño y ejecución de un sistema es objeto de la Ingeniería de sistemas.

Una red es un sistema, que se caracteriza por ciertas notas que lo diferencian de otros tipos de sistemas. Una red de alcantarillado, la red eléctrica o la red telefónica, una red de riego, cierta red vial son, por ejemplo, sistemas, pues están constituidas por elementos interrelacionados; pero el sistema solar no es una red; tampoco lo es un reloj ni el cuerpo humano, aunque el sistema de éste contiene redes, como las de los vasos sanguíneos o de los nervios. La especificidad de un sistema que se organiza como red estriba en que la relación de sus elementos se hace consistir en la comunicabilidad y comunicación de algo: las aguas, en las redes de alcantarillados; la electricidad en aquellas eléctricas; los sonidos, en las telefónicas; la sangre en la red vascular de ciertos cuerpos animados; los impulsos eléctricos en las redes nerviosas; las imágenes en las redes televisivas; toda clase de información en las redes computacionales, etcétera. Por cierto, como toda red es un sistema, puede haber redes incorporadas en ciertos sistemas que en sí mismos no consisten en redes: así, un reloj, que principalmente es una sistema de piezas mecánicamente interrelacionadas, contiene una red de fuerzas, en la medida en que unas piezas las comunican a otras. En consecuencia, la red de fuerzas viene a ser un subsistema del sistema mecánico del reloj.

Nada más que estos conceptos elementales necesitamos para darnos cabal cuenta de que el artículo 11 de la ley se excedió desmesuradamente al mencionar las redes y los sistemas como posibles objetos de pignoración. Las redes y los sistemas no son cosas, sino relaciones de cosas. Se podría pignorar, por consiguiente, las cosas corporales e incorporales muebles que constituyeran sus elementos; pero sólo en cuanto tales cosas; no su interrelación, que no es una cosa.

Examinemos algunos ejemplos.

En primer lugar, el de una red física destinada a la distribución de agua potable y a la recolección de aguas servidas ${ }^{38}$. Las tuberías, cámaras

${ }^{38}$ Se habla profusamente de "red" a lo largo del articulado del DFL. No 382 de 1988: Ley general de servicios sanitarios. Ahí mismo aparece siete veces la palabra 
de interconexión, motores y otros elementos, que componen tal red, no son muebles, sino inmueble por adherencia (artículo 570 CC.). Se los podría, pues, pignorar sólo como muebles por anticipación ${ }^{39}$, para cuando se los desarraigue del suelo, bajo el concepto, pues, de cosas futuras, en los términos expresamente previstos por el artículo 14 de la ley ${ }^{40}$. Pero al ser desarraigados, dejan de formar una red, que entonces va destruida, y la prenda sólo afecta a las piezas singulares desarticuladas. Esto es perfectamente posible; pero no es la pignoración de una red en cuanto tal. Ésta, en razón de inmueble, podría ser objeto de hipoteca, en el supuesto de que la propiedad de la red de tuberías, cámaras de interconexión, motores y otros elementos, aunque adherida al suelo, sea propiedad separada de la de éste y pertenezca a una persona distinta a la del dueño del suelo. Esta hipoteca, para ser tal, tendría que hacer posible la subasta de la red instalada, para que el subastador continúe en su empleo como red, cual sería el caso de la de cierta compañía de aguas que es vendida a otra. Todo lo anterior, sin hacer caudal de que la red de que hablamos supone una concesión pública, que constituye un derecho o cosa incorporal, susceptible de "ser objeto de cualquier acto jurídico en virtud del cual se transfiera el dominio o el derecho de explotación de la concesión" ${ }^{\prime \prime 1}$; y expresamente de prenda sin desplazamiento merced al artículo 6 No 5 de la nueva ley. Así que, en realidad, no se pignora la red física, sino el derecho de concesión que permitió su construcción, utilización y explotación. Un análisis semejante puede ser conducido con respecto a otras redes, como una de distribución de electricidad, constituida por el sistema de artefactos almacenadores de ese fluido, sus cables conductores y los postes y torres que los sostienen; o las redes telefónicas o de gases de uso doméstico.

Enseguida comparecen las redes y los sistemas computacionales, informáticos, cibernéticos, de procesamiento electrónico de datos o como quiera llamárselos, y es posible que en ellos hubiera pensado el autor de la peregrina idea de incluir las palabras sustantivas en el artículo 11. En sentido estricto ${ }^{42}$, se trata ahora de un conjunto de máquinas o equipos

"sistemas" (artículos 3 inciso 40, 45 incisos $1^{\circ}$ y $4^{\circ}, 52$ bis, 53 letras a) y b) y 1 transitorio, inciso $4^{\circ}$ ), en el mismo sentido que "redes".

${ }^{39}$ Argum. ex artículo 571 CC.

${ }^{40}$ Artículo 14: "La prenda sobre las cosas que la ley reputa como inmuebles por destinación o adherencia no tendrá otro efecto que ser una prenda sobre bienes futuros".

${ }^{41}$ Artículo 7 inciso $2^{\circ}$ del DFL. No 382, de 1988: Ley general de servicios sanitarios (DO. de 21 de junio de 1986),

${ }^{42}$ Para excluir otros elementos, como los métodos o procedimientos administrativos, con que la posibilidad de pignoración se hace aun más imposible. Unas nociones amplias encontramos en estas definiciones del tantas veces mentado ÁlvarEZ Osben, A., Diccionario, cit. (n. 15): “Terminología de procesamiento electrónico de 
computacionales interconectados, que hacen posible la transmisión, distribución e intercambio de información y servicios ("internet", correo electrónico, "chat", juegos). Ahora bien, en cualquier red de esta clase se puede distinguir, por un lado, la máquina, que suele ser llamada "hardware", y el programa o "software" por otro. La primera, como cosa corporal, normalmente mueble que es, sin perjuicio de poder devenir inmueble por destinación, está sometida al normal dominio o propiedad del artículo 582 CC., mientras que el segundo, está sometido a lo que antiguamente se llamaba propiedad intelectual (artículo 584 CC.) y que se describe mejor como una cosa intelectual inmueble, sometida al derecho de autor, en sus especies de derecho moral y patrimonial, que en Chile está regido por la Ley No 17.336. El artículo 3 No 16 de esa ley, en efecto, menciona los "programas computacionales" como protegidos por ella. Con independencia de que el programa mismo, que no debe confundirse con el disquete $\mathrm{u}$ otro instrumento que lo soporte, sea una cosa (intelectual), es claro que su pertenencia al comercio y circulación negocial es a través del derecho, especialmente patrimonial, sobre él recayente y que es el que interesa. El derecho patrimonial de autor sobre estos programas computacionales puede ser transferido o cedido a terceros para su explotación masiva, y, a tal efecto, su titular o cesionario puede otorgar licencias o autorizaciones pagadas para el uso del programa por terceros; tales licencias constituyen también derechos. Pero estas licencias suelen ser personalizadas, de modo que el programa pueda ser utilizado por su titular, sin que, en consecuencia, quede autorizada la copia del mismo programa por terceros Con todo esto, pues, entramos en el mundo de las cosas incorporales.

Por consiguiente, una red y un sistema computacionales son un complejo de cosas corporales e incorporales, que antes de pensar en su pignoración exigen aclarar el punto concerniente a si tienen dueños y quiénes serían éstos. Por cierto, no podemos entrar completamente en el examen de estas cuestiones y bastará la presentación de sus líneas fundamentales.

El asunto se presenta así: una red computacional puede tener un único dueño, por así llamarlo, si alguien lo es de todas las máquinas y además es titular del derecho de autor por origen o concesión de explotación o es titular de una licencia de uso, en todos los casos sobre la universalidad de los programas que utiliza la red. Podría ser el caso, por ejemplo, de una empresa de computación, que usa redes para su giro, con programas producidos por ella misma a través de máquinas que le pertenecen. Sin

datos”, p. 641: “Sistema ('System'): 1. Conjunto de procedimientos, procesos, métodos, rutinas, técnicas o equipo unido por alguna forma de interacción regulada para constituir una unidad organizada. 2. Colección de individuos, máquinas y métodos organizados para realizar una función específica”. 
embargo, este no es el caso normal. Generalmente, cada "nodo" personal de una red es dueńo de la máquina que emplea y titular de una licencia de uso de los correspondientes programas. No es infrecuente, empero, que haya un único dueño de todas las máquinas, que emplean programas de que aquél no fue autor, pero cuyos derechos adquirió por concesión del autor o ejerce por adquisición de una licencia de uso. Pero lo más frecuente es que en una red cada persona integrante sea dueña de su máquina y titular de la licencia de uso del programa que ella usa, y que no puede transferir a terceros. De este análisis se deduce que la transferencia en principio y, por consiguiente, la posibilidad de pignorar una red con todas sus máquinas y programas queda reducida al caso primero, de una persona o empresa, que sea dueña a la vez de todas las máquinas y titular de todos los programas. En los dos casos restantes, ya no cabe pensar en transferir ni en pignorar las redes, porque el enajenante o el pignorante, o no tienen derechos transferibles sobre los programas, o solo tienen dominio sobre su máquina y titularidad, generalmente no transferible, sobre su programa, pero no sobre las demás máquinas y programas.

Pero examinemos el único caso excepcional en que cabría la posibilidad de un acto jurídico sobre toda la red de máquinas y programas, por descansar el dominio de aquéllas y la titularidad de éstos en una única persona o empresa. No negaremos la posibilidad de considerar a tal red como una universalidad de hecho, que puede ser objeto de un único acto jurídico, por ejemplo, de cierta compraventa, que finalmente transfiera a un tercero la propiedad de las máquinas y la titularidad de los programas que haya en la red en el momento de la tradición. Este es un negocio posible y coherente, incluso con las necesidades prácticas del mercado, pues, en efecto, puede acontecer que haya un interesado en adquirir el mencionado conjunto para utilizarlo en su propio giro, no bien lo más posible sea que sólo se interese por los programas y no tanto por las máquinas, a menos que sean muy sofisticadas, o bien costosas cuando son nuevas. Ahora bien, aún así, lo vendido no es la red sino el conjunto de máquinas y programas que actúan en red, porque, es el caso repetirlo, las redes no son cosas sino relaciones de cosas. Da, pues, lo mismo que las máquinas y programas de que se trata actúen en red, pues lo vendido es el conjunto de cosas corporales e incorporales que la forman, aun cuando es preciso reconocer que su interrelación en red es la que permite configurar la universalidad. Mas, así como al ser vendida la universalidad del rebaño que pasta en el potrero No 5, lo que se vende es el rebaño y no la relación del rebaño con el pastizal del potrero No 5 , así también con la venta de las máquinas y programas que conforman tal red lo vendido son las máquinas y los programas, y no su interrelación. 
En fin hay un último punto por aclarar. Puede ocurrir que exista un programa computacional que consista en hacer posible una red, de modo que, al ser instalado en diversas máquinas, todas ellas queden insertadas en la red que el programa consiente. Que el autor de ese programa puede pignorar los derechos de su explotación, eso está fuera de duda. Se trata entonces de la pignoración de una cosa incorporal, vale decir, de los mencionados derechos. Pero no por ello la operación se convierte en una pignoración de una red. Así, por ejemplo, acaece con las redes operacionales usadas por los bancos, las cuales no son otra cosa que un programa que permite el registro de los ingresos en el haber de cada cuentacorrentista, por depósitos, abonos, acreditaciones, etcétera, y los egresos por giros, pagos de cheques, débitos, etcétera; todo ello "en línea" y contemporáneamente o "en tiempo real" o muy cercano al real ${ }^{43}$. El sistema o red que gobierna todas estas operaciones podría ser pignorado, mas no especialmente por ser un sistema, y como sistema, sino por ser un programa sobre el cual hay derechos de autor y como tales derechos en cuanto a su explotación.

En resumen, pues, que se pueda pignorar redes o sistemas, eso se reduce a la hipótesis muy particular y excepcional, de que una única persona sea dueña de todas las maquinas y titular de la autoría o de las licencias de todos los programas que la componen, de modo de poder pignorar el conjunto, pero no como red o sistema, sino como conjunto de cosas corporales e incorporales. La mención de redes o sistemas como objetos de pignoración está, pues, de más en el artículo 11 de la ley.

3. En el resto, la ley incurrió en omisiones al enumerar sus ejemplos. Se echan, en efecto, de menos los conjuntos de animales de beneficio o de tiro y carga, de semillas, frutos cosechados o de las maderas elaboradas, que son algunos tipos de bienes sobre los cuales se permitía prenda agraria ${ }^{44}$. Tampoco se mencionan los conjuntos de herramientas y útiles (al menos aquellos que no quepan bajo la idea de "maquinaria") ni los conjuntos de elementos de transporte terrestre (en la misma medida), que eran tipos admisibles para la prenda industrial ${ }^{45}$. En fin, también se echan en falta algunos conjuntos como los salmones de una salmonera y, más en gene-

${ }^{43}$ Este tipo de redes obedece al siguiente concepto ofrecido como $5^{\mathrm{a}}$ acepción de la voz por Álvarez Osben, A., Diccionario, cit. (n. 15): "Terminología de procesamiento electrónico de datos”, p. 630: “5. El 'teleprocesamiento', las líneas de comunicaciones que conectan un computador a una cantidad de terminales remotas. 'Terminal remota' es una unidad de control de entrada-salida y uno o más dispositivos de entrada-salida conectados a un enlace de comunicación”.

${ }^{44}$ Véase el artículo 2 de la Ley No 4.097 (DO. de 25 de septiembre de 1926 y de 25 de agosto de 1927)

${ }^{45}$ Véase el artículo 24 de la Ley No 5.687 (DO. de 17 de septiembre de 1935). 
ral, las especies en viveros, los combustibles almacenados, las colecciones de objetos artísticos o antiguos, de sellos, de monedas; las bibliotecas. El proyecto del Ejecutivo consideraba expresamente los muebles de una casa destinados a su ajuar, mas para prohibir su pignoración ${ }^{46}$, en seguimiento, por lo demás, del artículo 7 de la Ley No 18.112. Pero la norma del proyecto no subsistió y ya no hay razón para impedir la pignoración del ajuar.

Ahora bien, las omisiones señaladas y otras que aún podrían ser mencionadas en ningún caso significan que los respectivos conjuntos omitidos no sean pignorables, en la medida en que quepan bajo la fórmula general de conjuntos de bienes de una misma clase o universalidades de hecho. Cabe insistir, una vez más, en que la enumeración contenida en el artículo 11 es meramente ejemplar y no taxativa.

\section{FUNGIBILIDAD O INFUNGIBILIDAD DE LOS GRUPOS O UNIVERSALIDADES PIGNORADOS}

1. La prenda con desplazamiento debe recaer sobre cosas no fungibles. Tal exigencia de infungibilidad está destinada: i) a hacer efectiva la prohibición de usar y disponer de las cosas pignoradas que pesa sobre el pignoratario, la cual se hace imposible de controlar cuando se trata de fungibles, pues estos pueden ser dispuestos y después repuestos; ii) a asegurar que lo devuelto al extinguirse la prenda sea lo mismo que fue pignorado, por la misma razón antes dicha; y, sobre todo, iii) a permitir, en el caso necesario, la vindicación del derecho real de prenda, que implica la persecución de los objetos pignorados frente a terceros que los poseen o tienen, y frente al pignorante, que es su dueño, para ejercer la facultad de retención o en función del desposeimiento a efectos de la realización de la garantía. El pignorante debe estar en condiciones de poder decir: éste es el objeto que reclamo merced a mi derecho de prenda; pero ello no es posible si se está en presencia de fungibles.

La infungibilidad de una cosa deriva, al máximo, de la individualidad natural u objetiva de su forma y figura, que permite la identificabilidad de la misma cosa, y su inconfundibilidad con y su insustituibilidad por otras. La infungibilidad también puede provenir de la acuñación o impresión industrial de un código, marca, clave o serie individuales e irrepetidas en el cuerpo de ciertas cosas que, sin ellos, serían fungibles, y que, con ellos, siguen siendo tales, si no se los registra fidedignamente. Tal ocurre, por ejemplo, con los automóviles y vehículos motorizados en general, con ciertas máquinas y herramientas, con algunos artículos electrodomésticos y

${ }^{46}$ Artículo 5 inciso $7^{\circ}$ al final. 
con muchos otros tipos de productos. Lo propio acaece como consecuencia de la costumbre de marcar a fuego a los animales que forman rebaños. Una fungibilidad natural también puede ser superada cuando se fija la circunstancia de un lugar para el almacenaje del objeto, del cual no puede éste ser extraído, porque ese lugar permite la individualización del objeto, como si se designa el trigo, un fungible natural, que se halla depositado en el silo No 5 o el millón de pesos guardados en la gaveta izquierda de tal escritorio ${ }^{47}$. También los fungibles encerrados en embalajes, cajas, arcas, envoltorios, etcétera, convenientemente cerrados y sellados, con prohibición de abrirlos, confieren individualidad a los fungibles contenidos en ellos ${ }^{48}$.

Una prenda con desplazamiento sobre fungibles no es prenda sino un crédito sometido a algunas reglas de la prenda. Suele llamársela "prenda irregular" ${ }^{49}$. Las diferencias entre ella y la prenda sobre no fungibles son tales y tan sustanciales, que es desorientador y fuente de confusión afirmar que sigue siendo prenda, en circunstancias que su verdadera naturaleza es la indicada. Acaece al respecto lo mismo que con el cuasiusufructo (artículo 789 CC.) y el depósito irregular (artículo 2221 CC.), que también son créditos, aunque sometidos a algunas reglas del usufructo o del depósito regular.

2. La exigencia de infungibilidad del objeto es un carácter que se conserva en la prenda sin desplazamiento, por aplicación de la parte final del artículo 1 de la nueva ley. Pero el punto está sometido a una especial disciplina en el caso de prenda sobre grupos de bienes o universalidades de hecho.

Acontece que los componentes de los grupos de bienes o universalidades de hecho, pignorables según el artículo 11, son frecuentemente fungibles, porque se trata de cosas que la naturaleza o la industria humana generan en serie; y cuando pueden dejar de serlo si se deja anotado el código, marca, clave o serie que suele imprimirse en el cuerpo de algunos de ellos, conservan, empero, su calidad de fungibles, si no se los anota. Por lo demás, algunos de los componentes de los conjuntos pignorables según el artículo 11 no ofrecen ni siquiera esa peculiaridad, como ocurre con los cereales, generalmente con las materias primas, con la mayoría de los frutos y con

${ }^{47} \mathrm{Cfr}$. unas aplicaciones de esta manera de desfungibilizar cosas fungibles a los legados, que hace el artículo 1112 CC. y a la venta, que hace el artículo 1821 inciso $1^{\circ} \mathrm{CC}$.

${ }^{48} \mathrm{Cfr}$. una aplicación al depósito de fungibles contenidos en arcas cerrada, que hace el artículo $2221 \mathrm{CC}$.

${ }^{49}$ Sobre ella: Cruz Moreno, María, La prenda irregular (s. 1. [pero Madrid], Centro de Estudios Registrales del Colegio de Registradores de la Propiedad y Mercantiles de España, s. d [pero 1995]). 
infinidad de otros productos. En cuanto a las otras maneras de desfungibilizar, ellas no son eficaces para tal función, como quiera que el artículo 11 inciso $1^{\circ}$ de la ley concede al pignorante, salvo pacto en contrario, las facultades de utilizar, reemplazar, transformar y enajenar los componentes de los grupos de bienes o universalidades de hecho pignorados, así que, por más que se fije un lugar para su depósito o se los encierre en embalajes, cajas, arcas, etcétera, aun así el pignorante podría legítimamente operar de tal manera con ellos, que se pierda su rastro.

Estas observaciones, por cierto, no ocultan que a veces los conjuntos pueden estar compuestos por cosas corporales no fungibles, como cuando se trata de una pinacoteca, por ejemplo, cuyas pinturas, en efecto, son infungibles; o como suele acaecer en todas las colecciones artísticas en general o en los conjuntos formados por animales selectos, como si se trata de una caballería de puras sangre, cada uno de cuyos componentes tiene un nombre propio, que es capaz de reconocer y al cual obedece, y ofrece otras características físicas que permiten su fácil individualización.

3. Ahora bien, una cosa es la fungibilidad o infungibilidad de los componentes del grupo de bienes de una misma clase o de la universalidad de hecho pignorados y otra la fungibilidad o infungibilidad del grupo o de la universalidad mismos. La prenda con desplazamiento que regula el artículo 11 recae sobre tales grupos o universalidades; no sobre sus componentes individualmente considerados. En consecuencia, la general exigencia de infungibilidad del objeto de la prenda de que tratamos se aplica precisamente a unos u otras, como tales, con independencia del carácter fungible o infungible de sus componentes. Lo cual no significa que los componentes carezcan de influencia en la fungibilidad o infungibilidad del grupo o de la universalidad a que pertenezcan. Lo mejor será ofrecer un ejemplo: supongamos que se trata de la universalidad constituida por automóviles nuevos de tal marca, modelo y año. Es claro que estos objetos son fungibles entre sí y con respecto a otros automóviles de sus mismas características. El conjunto mismo es también fungible, porque puede ser confundido e intercambiado con otros conjuntos de automóviles de iguales apariencias. Más, cuando se lo describe como "conjunto de automóviles de tal marca, modelo y año sito en tal bodega", la fungibilidad del conjunto desaparece, aunque sus componentes mantengan el carácter de fungibles.

Este ejemplo es ilustrativo de la manera de construir la infungibilidad de los conjuntos. Para que ellos sean considerados como infungibles, en efecto, es necesario dejar constancia de las características genéricas, pero no individuales, de sus componentes, más un añadido especificador del conjunto mismo. En el ejemplo, el añadido es el lugar en el que éste se 
guarda $^{50}$. Si hemos recalcado la necesidad de abstenerse de señalar las características individuales de los componentes es para evitar que la prenda del conjunto se convierta en prenda de los componentes singulares. Al respecto, nos remitimos a lo antes expresado ${ }^{51}$.

4. Supuesto, pues, que el conjunto debe ser infungible, o construido como tal, y claro que eso es compatible con la fungibilidad de sus componentes, recordemos ahora que también puede darse el caso de conjuntos infungibles integrado por componentes también infungibles. Puede ser el caso de una colección de pinturas, o de una caballería de puras sangre, cuyos individuos son no fungibles por naturaleza. Dejando a un lado que en muchos casos de tales conjuntos haga defecto un interés en su pignoración bajo el régimen del artículo 11 (como seguramente sería el caso de la colección de pinturas), sin perjuicio de su pignoración sin desplazamiento bajo régimen general, la regla que las rige en la materia en estudio es la misma: por un lado, hay que evitar la caracterización de cada individuo y, por otro, hay que caracterizar en términos de infungibilidad al conjunto.

Que un conjunto pignorable puede estar integrado por no fungibles, está expresamente reconocido por el inciso $4^{\circ}$ del artículo 11 de la ley, el cual exige que el contrato de prenda deba señalar: "las particularidades tendientes a individualizar los bienes prendados, señalando si son fungibles o no [...]". La primera frase se refiere al conjunto pignorado; la segunda, a sus componentes; $y$ es en este punto en el que se reconoce, pues, que dichos componentes pueden ser fungibles o infungibles.

\section{EL PIGNORANTE}

Es una regla general de la nueva ley, ya antes anotada, que la pignoración de que ella trata es posible sobre toda clase de muebles y para garantizar toda clase de créditos. De ello se sigue que cualquier sujeto puede ser pignorante y pignoratario, siempre que reúnan, por cierto, las condiciones de capacidad generales establecidas por las leyes. Por lo demás, tal ya era un rasgo introducido por la Ley No 18. 112, que la nueva ley no hace más

${ }^{50}$ Se podría levantar una objeción: que al señalar un lugar para el conjunto se lo está señalando para cada individuo; y que eso es lo mismo que indicar, por ejemplo, el número de motor de cada automóvil; de lo que resulta la desfungibilización de cada componente y la conversión, por ende, de la prenda sobre una universalidad en prenda sobre muchas cosas infungibles. Pero la diferencia salta a la vista: indicado el número de motor de cada automóvil, ya por eso se lo hace no fungible y sigue siendo tal aunque salga del lugar previsto; mientras que indicado el lugar para el conjunto, la salida de un automóvil hace desaparecer la infungibilidad de que gozaba mientras estuvo en el lugar.

${ }^{51}$ Véase, más arriba, el capítulo VII, 1. 
que recoger. En ese rasgo, ambas, pues, contrastan ostensiblemente con las prendas especiales, como la agraria o industrial, que debían recaer sobre cosas especiales y para garantizar especiales deudas, de modo de quedar abiertas al uso de sólo personas especiales. Verdad es que la nueva ley contiene de hecho prendas especiales por su objeto, su crédito garantizable, su pignorante y su pignoratario, como son las enumeradas en su artículo 6, relativo a la pignoración de derechos de concesión. Pero eso sólo significa que la pignoración de tales derechos se sujeta, en lo demás, a las reglas de la nueva ley; mas no elimina el carácter general y común de la prenda sin desplazamiento que no recae sobre los mencionados derechos.

Lo que se ha mirado como rasgo general de la nueva ley, es aplicable a la prenda de conjuntos regulada por su artículo 11 . También ella está abierta a toda clase de conjuntos, para garantizar toda clase de deudas y para ser constituida por y a favor de toda clase de personas. Esta es una deducción natural de las reglas generales contenidas en la misma ley y de la ausencia de normas limitadoras en el artículo 11. Incluso más, en el "Mensaje" del Ejecutivo, estaba prevista la prohibición de pignorar "los muebles de una casa destinados a su ajuar" ",2 bajo el concepto implícito de ser necesaria semejante prohibición, porque sin ella podrían ser pignorable tales muebles en aplicación de la regla general que permite la prenda de conjuntos, entre los cuales precisamente están los mencionados muebles de una casa. Ella era consecuencia de la amplia cobertura concedida a la prenda de conjunto, que la hacía capaz de abarcar a los particulares con respecto a los muebles de su casa. Con este carácter, la nueva ley innova en la generalidad de las legislaciones extranjeras, que suelen reservar la prenda sin desplazamiento de conjunto precisamente a las empresas.

Sin embargo, la letra del artículo 11 en parte traiciona tan amplio diseño, porque no es posible dejar de notar que la accesibilidad de la prenda descrita en él es más propia de una empresa fabril, comercial o de servicios que de un sujeto general de Derecho civil. Tal es, en efecto, la impresión que provoca una dicción que recurre a términos como existencias, inventarios, materias primas, productos elaborados o semielaborados o repuestos, o maquinarias, redes o sistemas, más adecuados a las actividades fabriles y comerciales que a la generalidad de los ciudadanos en sus relaciones normales de Derecho civil común y general.

Pero el asunto debe dejarse en el plano nada más que de una impresión y no debe ir hasta convertirse en un estatuto. Se reitera, así, lo dicho

${ }^{52}$ Véase: Historia, p. 71. 
precedentemente, en orden a que, pese al lenguaje anotado, la prenda de conjuntos del artículo 11 es general y no sólo para las empresas ${ }^{53}$.

\section{APLICACIÓN DISPOSITIVA DE LOS COMPONENTES DEL GRUPO DE BIENES O UNIVERSALIDAD DE HECHO PIGNORADOS}

1. Acerca de las facultades del pignorante con respecto a los componentes del conjunto pignorado, la ley ofrece dos normas, una especial y otra general.

a) La parte final del inciso $1^{\circ}$ del artículo 11 de nuestra ley establece en forma especial: "[...] los componentes de los mismos podrán ser utilizados, reemplazados, transformados o enajenados, en todo o en parte, salvo pacto en contrario". Se tendrá presente que la expresión "los mismos" alude a "los grupos de bienes de una misma clase o universalidades de hecho" precedentemente mencionados en la disposición.

La norma es supletoria de la voluntad de las partes; rige, pues, en su silencio; pero puede ser excluida merced a un expreso pacto, en orden a que los componentes del grupo o universalidad pignorados no puedan ser utilizados, reemplazados, transformados o enajenados. Si se trata de un pacto que impide la enajenación, por el artículo 17 está mandado que de ese pacto se deje constancia en la inscripción del contrato en el Registro de Prendas sin Desplazamiento; y que la infracción del pacto haga que la deuda sea considerada como de plazo vencido, de modo que el acreedor pueda realizar la prenda ${ }^{54}$, previa su vindicación contra el actual poseedor

${ }^{53} \mathrm{Ni}$ siquiera vale anotar que la finalidad declarada de la nueva ley fue superar las "dificultades para acceder al crédito para la industria de capital de riesgo", como se dice en el "Mensaje" (véase Historia, p. 25), que limitaría no sólo el artículo 11, más toda la ley a los empresarios por deudas empresariales, si así podemos llamarlas. En la expresión "industria de capital de riesgo", la palabra "industria" no se usa en el sentido de empresa industrial ya constituida, sino de actividad industrial que puede estar constituida como una empresa en forma o puede ser un proyecto; así que basta la industriosidad. Típico ejemplo es el del joven que ha inventado un nuevo producto, cuya explotación debe producir importantes beneficios, pero que carece de capital para iniciar su explotación y no encuentra bancos e instituciones de crédito dispuestos a financiarla. Aunque este individuo no es un industrial, en el sentido formal de la palabra, lo es en su sentido funcional. La ley, en realidad, no pretendió superar tanto las dificultades de la empresa o del empresario cuanto las del emprendedor. Ahora bien, un emprendedor que necesita capital de riesgo normalmente no es un empresario formal, sino una persona civil general y común. Si tiene, pues, conjuntos que ofrecer en prenda, por ejemplo, una importante colección de arte, que podría vender, no se ve por qué haya de impedírsele pignorarla.

${ }^{54}$ Artículo 17: "Si se ha convenido que las cosas dadas en prenda no pueden gravarse o enajenarse, deberá mencionarse en el registro y su infracción dará derecho al acreedor 
o tenedor. Es preciso advertir que en el artículo 17 se habla de un convenio en orden a que "las cosas dadas en prenda" no puedan enajenarse; y aplicado él a la materia en examen, significa la no enajenación del grupo de bienes de la misma clase o universalidad de hecho, como tales; así que el pignorante podría extraer componentes singulares de esos conjuntos y enajenarlos; por lo cual es aconsejable que las partes convengan que la prohibición no sólo afecta al conjunto, mas también a sus componentes.

Por otra parte, el artículo 19 prescribe en general: "Si se ha convenido un lugar en donde deba mantenerse la cosa empeñada, ésta no podrá trasladarse. Asimismo, si se ha convenido que la cosa empeñada se utilice de una forma especificada en el contrato, ésta no podrá utilizarse de forma distinta a lo pactado. Las prohibiciones anteriores rigen salvo que el acreedor consienta en ello o que el tribunal competente del lugar de suscripción del contrato decrete su traslado o uso distinto para su conservación. En caso de infracción a lo dispuesto precedentemente, el acreedor podrá exigir la inmediata realización de la prenda, considerándose la obligación caucionada como de plazo vencido". Nos interesa la dicción relativa a a la utilización.

Esta norma general permite a las partes del contrato prendario convenir que la cosa en prenda sin desplazamiento sea utilizada de una forma que vaya especificada en dicho contrato. Aplicada ella a la pignoración de conjuntos, puede ser entendida como la autorización para convenir que sus componentes sean utilizados de una forma especificada. En este contexto, el verbo "utilizar" debe ser entendido en sentido amplio, hasta incluir la utilización, el reemplazo, la transformación o la enajenación, y no en el restringido de mero uso o aplicación no consuntiva ${ }^{55}$, como habría que entenderlo en el contexto de otro tipo de pignoraciones. En efecto, si por el inciso $1^{\circ}$ del artículo 11 está permitido a las partes acordar que nada de aquello se pueda hacer, no se ve por qué no pudieran pactar que todo eso se haga, pero de una manera especificada.

Ahora bien, supuesto el convenio de utilización específica, aún así el pignoratario puede después consentir una distinta al pignorante; y tampoco nada impide que, si previamente se había acordado que absolutamente no pudiera haber utilización, reemplazo, transformación o enajenación, con posterioridad el pignoratario consienta alguna al pignorante. Un uso distinto también puede ser decretado por el tribunal competente, pero en

para exigir la inmediata realización de la prenda, considerándose la obligación caucionada como de plazo vencido. [...]".

${ }^{55}$ Podría interesar al pignorante que los componentes consumibles del conjunto pignorado sean dispuestos en la fabricación de tal línea de productos finales, de los varios posible en la empresa del pignorante, y no de tal otra, porque, por ejemplo, la primera incorpora mayor valor que las demás y así la prenda queda robustecida. 
función de conservar la cosa, así que ahora el verbo "usar" está empleado en el sentido técnico de aplicación no consuntiva, porque de conservar la cosa se trata; de modo que el tribunal no tiene competencia para conocer de cambios en las aplicaciones consuntivas o dispositivas.

Si el pignorante, sin consentimiento del acreedor, infringe el original convenio de utilización específica o la autorización de uso específico dada por el tribunal; o si infringe los términos del consentimiento del acreedor dado para una utilización distinta a la inicialmente acordado, la deuda caucionada se considera como de plazo vencido y el acreedor puede proceder a la realización de la prenda. La ley no sanciona en forma expresa el caso de contravención del pacto que impide absolutamente la utilización, el reemplazo o la transformación de los componentes. Pero ciertamente está permitido a las partes acordar que en ese caso se considere como de plazo vencido a la deuda y quede consentido realizar la prenda al acreedor.

b) Si ahora coordinamos los artículos 11 inciso $1^{\circ}$ y 19 , entonces el régimen relativo a qué aplicación dar a los componentes del conjunto pignorado se presenta así: i) en el silencio de los contratantes, para el pignorante rige una amplia facultad de utilización, reemplazo, transformación o enajenación de tales componentes, como detallaremos después; ii) las partes pueden pactar expresamente que dichos componentes no puedan ser utilizados, reemplazados, transformados o enajenados; iii) en el caso de un pacto de no enajenación, de éste debe dejarse constancia en la inscripción del contrato, y su contravención hace caducar el plazo y permite realizar la prenda; iv) la contravención del pacto de no utilización, reemplazo o transformación no tiene sanción expresa, pero las partes pueden, de acuerdo con las reglas generales de la autonomía privada, pactar la caducidad del plazo y la posibilidad de inmediata realización de la prenda; v) también pueden pactar que los componentes sólo sean utilizados de una forma especificada en el contrato, en donde el verbo "utilizar" debe ser entendido en sentido amplio, hasta abarcar el uso, el reemplazo, la transformación o la enajenación; vi) con posterioridad a los dos pactos dichos, el pignoratario puede autorizar, bien una plena utilización en caso de haber quedado antes plenamente prohibida, o una utilización diversa a la especificada; vii) el tribunal puede autorizar un uso, y sólo un uso, diverso al especificado entre las partes, en función de la conservación de la cosa; viii) la transgresión de las autorizaciones del acreedor o del tribunal hacen caducar el plazo y permiten realizar la prenda.

2. Bajo el supuesto de un silencio de quienes celebraron el contrato prendario, la parte final del inciso $1^{\circ}$ del artículo 11 confiere, como adelantamos, un amplio poder de uso y disposición al pignorante, en cuya tenencia han quedado los componentes del grupo o de la universalidad pignorados. 
El uso, vale decir, cualquier aplicación de una cosa, sea la natural o que corresponda a su estructura y función, o no lo sea, siempre que no siga la destrucción o el menoscabe como efectos normales de la aplicación ${ }^{56}$, está mencionado directamente, en cuanto se permite poder "utilizar" los componentes.

La disposición física va representada por la autorización para "transformar", vale decir, para convertir las cosas pignoradas en otras, como es normal en los procesos fabriles, en que, a partir de una cierta materia prima se elabora una especie distinta.

La disposición jurídica total deriva del verbo "enajenar".

La ley no menciona la facultad de disposición jurídica parcial, consistente en la imposición de gravámenes reales a una cosa. Que en el caso de los conjuntos muebles a que se refiere el artículo 11, pueda o no ser lícito gravarlos con derechos reales, eso sólo cabe investigarlo con respecto a los de usufructo, uso y prenda, únicos que pueden o deben ser muebles, por la cosa corporal en que pueden o deben recaer (artículos 580 CC.). Pero esta indagación es fácil con respecto al caso más normal, de si un conjunto ya pignorado puede volver a serlo, porque es aplicable la regla general contenida en el artículo 16 de la ley, según el cual se pueden constituir una o más prendas sobre un mismo bien ${ }^{57}$; así que la respuesta es positiva. Es necesario añadir que el artículo 17 permite a las partes convenir que las cosas dadas en prenda no puedan ser gravadas, siempre que de este convenio se deje constancia en la inscripción del contrato en el Registro de Prendas sin Desplazamiento. Aplicada la norma a nuestra materia, eso significa impedir la ulterior pignoración del grupo de bienes de la misma clase o universalidad de hecho que actualmente es objeto de una prenda, como tales, pero no de sus componentes, así que el pignorante podría extraer componentes singulares del conjunto, formar con ellos otro, que nunca fue pignorado, y proceder a darlos de nuevo en prenda, burlando así, el pacto de no gravamen. Por lo cual es aconsejable que las partes extiendan convencionalmente a los componentes la prohibición de gravar. La vulneración del pacto permite al acreedor hacer caducar el plazo y proceder a la realización de la prenda, en función de lo cual la puede vindicar contra los terceros tenedores o poseedores.

En cuanto a los derechos de usufructo y de uso, dejando a un lado la peculiaridad y excepcionalidad de la situación por crear, en realidad no

\footnotetext{
${ }^{56}$ Pero, de acuerdo con las reglas generales, se excluyen los accidentes debidos a caso fortuito o fuerza mayor.

${ }^{57}$ Artículo 16: "Se podrá constituir una o más prendas sobre un mismo bien, prefiriéndose por el orden cronológico de sus respectivas inscripciones en el Registro de Prendas sin Desplazamiento".
} 
hay razón para impedir tales derechos, en el entendido que el precedente derecho de prenda prevalece sobre el posterior usufructo o uso.

Se cierra el círculo de poderes con la facultad de "reemplazar". Este reemplazo se refiere, sin discusión, a la sustitución de los componentes del grupo o universalidad por otros de su misma especie y calidad, lo cual envuelve, normalmente, una disposición física o jurídica del componente reemplazado, pues para poder hacer lo uno o lo otro es que se lo reemplaza; pero aun cuando no fuera así, la ley permite el reemplazo sin expresión de causa. Puede haber dudas acerca de si el reemplazo sea posible con otros bienes distintos al componente reemplazado. Pero la respuesta debe ser negativa, porque el grupo de bienes de la misma clase o la universalidad de hecho pignorados deben su consistencia e individualidad a las cosas que los componen, reemplazadas las cuales, la pierden. Un rebaño de ovejas es tal porque contiene ovejas; si se las reemplaza por cabras, ya no es un rebaño de ovejas. Volveremos sobre el punto en otro contexto ${ }^{58}$.

2. Como consecuencia de las facultades reconocidas al pignorante, sus deberes y responsabilidades con respecto a la conservación de lo pignorado no son aplicables a aquel que constituyó prenda sobre grupos de bienes o universalidades de hecho. Acerca de cuáles son dichos deberes y responsabilidad, dice el artículo 18 de la ley: "El constituyente o el deudor prendario, en caso que fueren distintos, conservarán la tenencia, uso y goce de la cosa dada en prenda, siendo de su cargo los gastos de custodia y conservación. Sus deberes y responsabilidades en relación con la conservación de la cosa dada en prenda serán los del depositario, sin perjuicio de las penas que más adelante se establecen".

Ahora bien, la responsabilidad general de un depositario por la conservación de la cosa, salvo estipulación diversa, alcanza sólo hasta la culpa grave, que equivale al dolo (artículos 2222 incisos $1^{\circ}$ y $2^{\circ}$, en relación con el artículo 44 inciso $1^{\circ}$ CC.). Pero el mismo artículo 2222 No 2 CC. establece que si el depositario "tiene algún interés personal en el depósito, sea porque se le permita usar de él en ciertos casos, sea porque se le conceda remuneración", responde hasta de la culpa leve. Como el pignorante, por el mismo artículo 18 de la ley, tiene concedida autorización para el uso de lo pignorado, se sigue que su responsabilidad alcanza precisamente hasta la culpa leve.

Sin embargo, nada de esto es, en principio, aplicable al pignorante de grupos de bienes o universalidades de hecho. El artículo 18, en efecto, continúa así: "Con todo, los deberes, responsabilidades y penas mencionadas no serán aplicables en el caso que legitimamente se haya procedido conforme

${ }^{58}$ Véase, más abajo, el capítulo XIII, 1, b). 
al artículo 11 precedente". Así que tal pignorante no responde por culpa de ninguna especie ni por dolo, de la conservación de lo pignorado. Lo cual deriva de que la autorización que lo favorece alcanza, como vimos, no sólo al uso, más incluso a la disposición física y jurídica.

Mas, para que así sea, menester es que el pignorante haya procedido "legítimamente". En lo civil, eso significa que no haya transgredido algún acuerdo prendario, como aquellos permitidos por los artículos 11 inciso $1{ }^{\circ}$ parte final, en orden a no utilizar, reemplazar, transformar o enajenar absolutamente; 17 , en orden a no enajenar o gravar; o 19, en orden a una utilización especificada en el contrato.

3. El artículo 18 exonera incluso de las penas al pignorante de grupos de bienes o universalidades de hecho que dispuso de unos u otras o de sus componentes singulares. Ello significa que dicho pignorante, en principio, no comete los delitos tipificados en el artículo 39 de la ley, el cual, en efecto, dispone: "Serán castigados con las penas señaladas en el artículo 473 del Código Penal:/ 1) El que defraudare a otro disponiendo de las cosas constituidas en prenda en conformidad a esta ley, sin señalar el gravamen que las afecta o constituyendo prenda sobre bienes ajenos como propios, o alzando la prenda que haya cedido;/2) El deudor prendario y el que tenga en su poder la cosa constituida en prenda en conformidad a esta ley que, defraudando al acreedor prendario, la altere, oculte, sustituya, traslade o disponga de ella, $y / 3$ ) El deudor prendario que, tratándose de prendas de créditos o de cualquier otra clase de derechos constituidos en prenda en conformidad a esta ley, defraude al acreedor prendario, ocasionando la pérdida o el menoscabo de los derechos otorgados en garantía".

Desde un punto de vista penal, en la ejecución de cualesquiera de las conductas tipificadas en esta norma, que envuelvan disposición física o jurídica, traslado, o reemplazo de los componentes del conjunto pignorado, el pignoratario de grupos de bienes o universalidades de hecho se ve favorecido por la circunstancia eximente de responsabilidad descrita en el artículo 10 No 10 del Código Penal: "Están exentos de responsabilidad criminal:/ $10^{\circ}$ El que obra [...] en el ejercicio legítimo de un derecho [...]"; así que no comete delito por estar justificada su conducta. Se observará que la formulación general de esta eximente en el Código Penal, en orden a que sea legítimo el ejercicio del derecho coincide con la exigencia particular del artículo 18 de la ley que manda no aplicar las penas en el caso en que "legítimamente" se haya procedido conforme al artículo 11. Esto es sumamente importante en la especie, porque si el pignorante enajena o dispone los componentes de los grupos de bienes o universalidades de hecho pignorados para, por ejemplo, defraudar al pignoratario, su obrar ya no es en ejercicio legítimo de un derecho, en los términos del artículo 
10 No 10 CPen., ni está en el caso de haber procedido legítimamente conforme con el artículo 11 de la ley, en los términos de su artículo 18 ahora. Lo propio acaece si el pignorante transgredió alguno de los pactos permitidos por los artículos 11 inciso $1^{\circ}$ parte final, sobre no utilizar, reemplazar, transformar o enajenar absolutamente; 17 , sobre no enajenar o gravar; o 19, sobre una utilización especificada en el contrato.

\section{CONSTITUCIÓN LEGAL DE UNA NUEVA PRENDA SOBRE LOS BIENES TRANSFORMADOS O ELABORADOS CON COMPONENTES DE UN GRUPO O UNIVERSALIDAD PREVIAMENTE PIGNORADOS}

El inciso 2० del artículo 11 dispone: "Los bienes transformados en virtud de lo dispuesto en el inciso anterior asi como el producto elaborado con los componentes de dichas existencias, quedarán de pleno Derecho constituidos en prenda".

Estas normas, como se ve, distingue dos casos: i) el de los bienes transformados; y ii) el del producto elaborado con los componentes de "dichas existencias".

1. Como en su momento vimos, el inciso $1^{\circ}$ del artículo 11 autoriza al pignorante para transformar los componentes de los grupos de bienes de una misma clase o universalidades de hechos que fueron objeto de pignoración.

a) El inciso $2^{\circ}$, pues, con su remisión "al inciso anterior", esto es, al $1^{\circ}$, atañe a los bienes generados merced al proceso de la transformación de tales componentes, que denomina "bienes transformados", como ocurre, por ejemplo, cuando de lingotes o planchas de cobre que fueron pignorados, supongamos que como inventario de materias primas, se fabrica cañerías o fibras trenzadas de cobre: las cañerías o las fibras trenzadas son, pues, bienes transformados.

b) El mismo inciso $2^{\circ}$ se refiere también al "producto elaborado con los componentes de dichas existencias". Ahora bien, el inciso $1^{\circ}$ del artículo 11 , según se recordará, enuncia una lista (no taxativa) que incluye nueve miembros: existencias, inventarios, materias primas, productos elaborados, productos semielaborados, repuestos, maquinarias, redes y sistemas; y en esta lista cada uno de sus miembros constituye un elemento autónomo y separado de los demás. Por consiguiente, la referencia al "producto elaborado con los componentes de dichas existencias", da a entender que ella es sólo al primer miembro de la lista, de modo que sólo los productos elaborados a partir de existencias (además de los bienes transformados) son los que quedan cubiertos con la prescripción de la norma, mas no los productos elaborados con los componentes de los inventarios, materias primas o productos semielaborados que fueron objetos de pignoración; o, más en 
general, con los componentes de los grupos de bienes de una misma clase o universalidades de hecho pignorados, salvo que sean existencias.

Hay que desatender, empero, tal tenor literal, porque el sentido que él da a esta ley no es claro. No hay razón que justifique el pensamiento de que los productos elaborados con los componentes, por ejemplo, de un inventario o de ciertas materias primas pignorados no deben quedar pignorados ellos mismos, según el inciso $2^{\circ}$ en examen, como sí debe ocurrir a los productos elaborados con los componentes de unas existencias dadas en prenda. La razón o espíritu de esta ley, que es la de imponer la pignoración de pleno Derecho, vale tanto para los productos elaborados con los componentes de unas existencias, como para los elaborados con los de inventarios, materias primas y demás miembros de la lista que acepten la idea de elaboración a partir de ellos. Así que la frase: "con los componentes de dichas existencias" debe ser leída como si dijera: "con los componentes de dichos grupos de bienes de una misma clase o universalidades de hecho", porque la prenda de pleno Derecho es pensada por la ley para todos los componentes de los conjuntos pignorables según el artículo 11.

c) Por lo demás, la referencia a "dichas existencias" se debe a una inadvertencia en que se incurrió cuando la redacción debida a una (primera) indicación sustitutiva del Ejecutivo, de que da cuenta el informe de la Comisión de Constitución, Legislación y Justicia de la Cámara de Diputados, fue cambiada a la que ahora vemos en la ley (y que provino de una segunda indicación sustitutiva del Ejecutivo presentada en la Comisión de Hacienda del Senado ${ }^{59}$ ), según se aprecia en la siguiente comparación:

Primera indicación sustitutiva, artículo 12 incisos $1^{\circ}-3^{0^{60}}$

"[inciso $1^{\circ}$ ] En el caso de existencias de mercaderías, materias primas, grupos de bienes de una misma clase, inventarios, productos elaborados o semielaborados y repuestos del comercio o industrias y, en general, de cualquier actividad de la producción o de los servicios,
[Segunda indicación sustitutiva $=]$ Ley No 20.190, artículo 11 incisos $1^{\circ}, 2^{\circ}$ y $3^{\circ}$

"[inciso 10] En el caso de prendarse grupos de bienes de una misma clase o universalidades de hecho, tales como existencias, inventarios, materias primas, productos elaborados o semielaborados o repuestos, o maquinarias, redes o sistemas;

${ }^{59}$ Véase la nota 2.

60 "Informe de la Comisión de Constitución, Legislación y Justicia de la Cámara de Diputados" (cuenta en sesión No 48, de 13 de enero de 2004, Legislatura No 350), en Historia, p. 297. 
los componentes de dichas existencias podrán ser utilizados, transformados o enajenados, en todo o en parte. [...].

[inciso $2^{\circ}$ ] Los bienes transformados en virtud de lo dispuesto en el inciso anterior, como asimismo el producto elaborado con los componentes de dichas existencias quedarán ipso jure constituidos en prenda.

[inciso $3^{\circ}$ ] Por su parte, aquellos componentes que salgan del conjunto empeñado quedarán subrogados por los que posteriormente lo integren hasta la concurrencia del total constituido en prenda". los componentes de los mismos podrán ser utilizados, reemplazados, transformados o enajenados, en todo o en parte $[\ldots]$

[inciso $2^{\circ}$ ] Los bienes transformados en virtud de lo dispuesto en el inciso anterior así como el producto elaborado con los componentes de dichas existencias, quedarán de pleno Derecho constituidos en prenda.

[inciso $3^{\circ}$ ] Aquellos componentes que salgan de la universalidad o grupo de bienes empeñados quedarán subrogados por los que posteriormente lo integren, hasta la concurrencia del total constituido en prenda".

En la primera indicación, la frase: "los componentes de dichas existencias" era suficiente, porque la parte inicial del inciso estaba montada sobre el concepto único de "existencias", de las que enseguida se ofrecían ejemplos, así que con aquella frase se cubría todo el contenido de esa parte inicial. En la ley, proveniente de una segunda indicación sustitutiva, que pasó a ser su artículo 11, cuyo inciso $1^{\circ}$ está montado, en cambio, sobre las ideas de grupos de bienes de una misma clase o universalidades de hecho, su redactor inicialmente alcanzó a darse cuenta del cambio y por ello escribió la expresión "los mismos" en la última parte de dicho inciso. Pero al redactar el inciso $2^{\circ}$ del indicado artículo 11 , sufrió una contaminación mental con la expresión "los componentes de dichas existencias", que aparecía correctamente en el inciso $7^{\circ}$ del artículo 5 de la primera indicación, y la repitió incorrectamente en la segunda, en vez de haber escrito algo así como: "de dichos grupos o universalidades", con el mismo cuidado que después volvió a tener para emplear una expresión semejante en el inciso $3^{\circ}$. Quien tenga experiencia en la crítica de textos comprende perfectamente este tipo de accidentes, tan frecuentes cuando se trabaja sobre la base de textos previos en los que se interpola redacciones posteriores, sin tener el cuidado de revisar minuciosamente el conjunto del texto final.

Así que, en final de cuentas, el inciso $2^{\circ}$ también se refiere al producto elaborado con los componentes de un grupo de bienes de una misma clase o universalidad de hecho pignorados, trátese de existencias, o trátese de cualesquiera de los demás extremos enunciados ejemplarmente en el inciso $1^{\circ}$ del artículo 11.

2. La distinción contenida en el inciso $2^{\circ}$, entre bienes transformados y productos elaborados con los componentes de un grupo de bienes o universalidad de hecho, que en algunos casos puede ser sutil, intenta cubrir todas las posibilidades que se dan en el proceso fabril. 
a) Podemos reducir a este esquema puro dichas posibilidades; pues una cosa puede ser fabricada: i) a partir de cierta materia prima merced a la sucesiva mutación de su forma hasta llegarse al producto final previsto en el proceso fabril de que se trata, como si de troncos de árbol se elaboran tablas, vigas, puntales y travesaños; o de cobre en lingotes o planchas se manufacturan tuberías o cables; o del trigo se fabrica harina; etcétera; o bien ii) merced a la mezcla meramente física de varios elementos que da lugar a una cosa distinta a cada constituyente inicial, como cuando se ligan cobre y estaño para dar lugar al bronce; asimismo iii) mediante la confusión química de varios elementos, que también da lugar a algo distinto, como cuando de la mezcla del harina, el agua y la levadura se compone la masa y de ésta pan; o a partir de varias drogas se compone un medicamento; o de ciertas sílices y óxidos, láminas de vidrio; etcétera; o, en fin, iv) en virtud de una composición predominantemente física, propiamente mecánica, de partes y piezas ya elaboradas, como dispositivos, módulos, instrumentos o artefactos, que aún cohesionadas conservan su individualidad a la vista, cual es el caso de un automóvil hecho de diferentes partes iniciales ensambladas o de cualquier máquina, aparato o mecanismo. En la práctica, estos tipos puros se combinan en las operaciones fabriles, que, por ende, suelen comprender procesos de transformación, de mezcla, de confusión y de composición.

La dicción del inciso $2^{\circ}$ del artículo 11 , pues, cubre todos estos procesos puros y también, desde luego, su combinación.

b) Pero, desde otro punto de vista, todo proceso de fabricación, dicho así en general, puede ser reconducido a una de las tres operaciones comprendidas en el Código Civil bajo el tipo de accesión "de una cosa mueble a otra" y distribuidas en especificación, mezcla y adjunción (libro II, título 50, \$3). El Código se interesa por ellas en cuanto intervengan personas no previamente ligadas por un contrato de arrendamiento para la confección de una obra material, un contrato de trabajo u otro contrato apropiado, que establezca cierto estatuto dominical a la cosa que entonces se forma, de modo que sea necesario ofrecer un criterio que resuelva el punto concerniente a su dominio. Lo cual no es el caso en los procesos fabriles empresariales del tipo de la mezcla o de la adjunción, porque, o bien todos los elementos intervinientes en una o en otra pertenecen a una misma persona, precisamente al empresario, o, en el caso diverso, hay un previo contrato de arrendamiento del género dicho entre él y los terceros, que regula el destino del objeto final; ni tampoco en los procesos del tipo de la especificación, que están regidos por el contrato de trabajo entre el dueño de la materia y el especificante o artífice, que es el trabajador, con el ańadido, a veces, de un contrato de arrendamiento ya mencionado con 
terceros. Mas, que así, sea, eso no quita su naturaleza de accesión a las operaciones mencionadas, que, como veremos, se manifiesta bajo otros respectos.

3. Ahora bien, el inciso $1^{\circ}$ del artículo 11 establece una pignoración de pleno Derecho, vale decir, por el sólo ministerio de la ley, con respecto a los conjuntos de bienes (en realidad de cosas corporales) transformados a partir de otros que habían sido pignorados como grupo o universalidad, y de los conjuntos de productos (asimismo de cosas corporales en definitiva) que fueron confeccionados a partir de los componentes del grupo o universalidad también pignorados. Así, por ejemplo, si un astillero pignoró sus existencias de madera semielaborada y con ellas construyó ciertas naves menores, según el dicho inciso son tales naves las que resultan al final pignoradas. Si una armaduría de automóviles pignoró el inventario de sus piezas y partes, con las cuales armó una serie de vehículos, son estos los que también quedan pignorados.

a) La norma fue necesaria, porque la transformación de bienes o elaboración de productos, de que habla puede involucrar una especificación de las materias iniciales pignoradas, la cual necesariamente las destruye, por más que la especificación conduzca a una cosa distinta ${ }^{61}$. Esta destrucción de las materias iniciales, aunque no extinga la prenda sobre el conjunto a que pertenecían, sí impide que el conjunto de bienes transformados pueda ser considerado bajo prenda. Así que la prenda constituida por el dueño de un astillero sobre ciertas existencias de madera semielaborada no puede transitar al conjunto de los botes construidos. Ello, en primer lugar, porque los botes dejaron de pertenecer al conjunto originalmente pignorado: en efecto, de ninguna manera puede considerarse que un conjunto de botes integre un conjunto de maderas semielaboradas. En segundo lugar, porque los bienes transformados forman un nuevo conjunto, que nunca fue antes pignorado, entre otras razones, porque no existía ${ }^{62}$.

La transformación o elaboración también puede implicar una adjunción. Ahora bien, lo propio de la adjunción es que el todo compuesto

${ }^{61}$ Sobre la transformación o especificación de una cosa como destrucción de la misma, véase: GuZMán BRITo, Alejandro, Destrucción y especificación de una cosa corporal, en Estudios de Derecho Civil III. Jornadas Chilenas de Derecho Civil, Valparaíso, 2007 (en prensa).

${ }^{62}$ Sin perjuicio de haber podido ser pignorado como cosa futura, en los términos del artículo 9; sólo que expresamente. Dice tal disposición: "El contrato de prenda sobre bienes o derechos futuros será válido, pero mediante su inscripción no se adquirirá el derecho real de prenda sino desde que los bienes o derechos empeñados lleguen a existir". Acerca de esta materia, véase: Guzmán Brito, Alejandro, La prenda sin desplazamiento de cosas corporales e incorporales futuras (en prensa). 
resulta ser algo nuevo. En consecuencia, si los componentes con que se manufacturó el bien transformado o el producto elaborado pertenecían a un cierto conjunto, su transformación o elaboración también los extrae de ese conjunto y los extrae de la prenda que en él recae; y los hace pasar a otro conjunto, que nunca fue pignorado. Si se fabrica, pues, martillos con mangos de madera, pertenecientes a un conjunto de tales pignorado, y con cabezas de hierro, pertenecientes a un conjunto de los mismos también pignorado, no hay modo de decir que los martillos pertenezcan a uno $\mathrm{u}$ otro conjunto, cuyas prendas sufren; pero sí se puede decir que los martillos forman un nuevo conjunto, que no había sido pignorado.

La transformación o elaboración puede finalmente implicar una mezcla, y entonces cabe el mismo razonamiento empleado en los casos sucesivos. Cuando se fabrica "pólvora" con la mezcla de nitrato de sodio, azufre y carbón vegetal, cada cual extraído del respectivo conjunto, no cabe decir que la pólvora haga parte de algunos de esos tres conjunto, mas que forma un conjunto propio; así que la prenda de los conjuntos de elementos iniciales no deambula al nuevo conjunto.

b) El inciso $2^{\circ}$ del artículo 11 , pues, rompe estas consecuencias dogmáticas de la elaboración o transformación, sea que impliquen especificación, adjunción o mezcla, e impone, en cualquier caso, que los bienes transformados o elaborados "quedarán [...] constituidos en prenda". De no haberse establecido así, el pignoratario empezaría a quedar sin garantía con la transformación o elaboración y resultaría sin sentido la autorización legal dada al pignorante para disponer de los componentes del conjunto pignorado, merced precisamente a su transformación o elaboración; así que esta pignoración del conjunto de las especies resultantes del proceso fabril por el ministerio de la ley es la contrapartida de dicha autorización.

4. Todavía la norma merece los siguientes comentarios:

a) Aunque ella, por mala redacción, no es explícita, resulta claro que los bienes transformados y los productos elaborados a que se refiere el artículo 11 inciso $2^{\circ}$ quedan pignorados de pleno Derecho como conjuntos, y no como objetos singulares. Tiene que ser así, porque de lo contrario se destruiría el principio de la pignoración de grupos o universalidades, sobre el cual está montado dicho artículo.

b) Se observará que la ley no dice que la prenda originalmente constituida pasa o se traspasa o traslada a los bienes transformados, o que éstos subrogan a los originales en la prenda, o algo semejante. El contraste entre la figura del inciso $2^{\circ}$, que ahora estudiamos, y la del inciso $3^{\circ}$, que habla de subrogación y estudiaremos, es al respecto definitivo. Dicho de otro modo, en el caso que examinamos queda constituida, o se constituye, una nueva prenda sobre los bienes transformados. 
c) En fin, digamos que el dispositivo del inciso $2^{\circ}$ del artículo 11 no se funda en la mera inconveniencia práctica para el funcionamiento de la noción de prenda de un conjunto frente a los acreedores, derivada de que el de bienes transformados y elaborados deba resultar libre de prenda; ni, por ende, en la pura voluntad del legislador, en orden a que sí deba quedar bajo prenda; mas tiene una razón dogmática. Supongamos que no se hubiera escrito el inciso $2^{\circ}$ del artículo 11 . Aún así, las partes del contrato prendario hubieran podido convenir en su actual contenido, bajo la consideración de que los bienes transformados y elaborados son futuros, cuya prenda es posible merced a lo dispuesto por los artículos 5 y 8, de modo de haberlos podido pignorar por anticipado. La ley, pues, procede bajo el mismo concepto y hace innecesaria la convención expresa de las partes, en orden a pignorar tales bienes como futuros, dejándolos pignorados ella misma. Lo cual no significa que sea supletoria de la voluntad de las partes, de guisa de poder ellas excluir la aplicación del inciso 2o. Éste es imperativo ("quedarán" dice) y no da lugar a un pacto en contrario.

5. Hasta el momento hemos supuesto que todos los elementos con que algo fue manufacturado se encontraran bajo prenda. Sin embargo, puede acaecer que en el proceso de transformación o de elaboración ingresen elementos que habían sido pignorados cada uno a distintos acreedores; o bien elementos previamente pignorados y elementos que no lo hubieran sido. Supóngase que un fabricante de vidrios había dado en prenda ciertas arcillas silíceas, una de las materias primas para la fabricación del vidrio, a un acreedor, y a otro los óxidos metálicos, que son la otra materia prima para ese producto; y que con ambas (más otros elementos secundarios que dejamos a un lado) fabricó el dicho producto, en la forma normal; o bien que había pignorado las arenas, pero no los óxidos.

6. La consecuencia dogmática de la primera hipótesis es la extinción de ambas prendas, porque invariablemente los bienes transformados o elaborados forman un conjunto nuevo, nunca constituido en prenda; $y$ ya no pertenecen a ninguno de los conjuntos que sí lo estaban en favor de diferentes acreedores. De nuevo, pues, la ley evita esta consecuencia desfavorable a los acreedores; y su artículo 12 ofrece la siguiente solución más favorable de reemplazo: "En caso que dos o más bienes prendados se confundieren, mezclaren o transformaren en uno indivisible o que su división causare detrimento en el valor de la cosa, los acreedores prendarios mantendrán sus derechos en el bien resultante a prorrata de sus créditos, sin preferirse por la antigüedad de sus cauciones".

a) La hipótesis básica es, pues, la ya explicada, que la norma describe como confusión, mezcla o transformación de dos o más bienes previamente pignorados. La dicción es suficientemente amplia como para incluir 
todas las posibilidades de combinación de dos o más cosas, en que puede consistir un proceso fabril, trátese de una combinación química, física (mecánica) o químico-física; y trátese de una adjunción o mezcla, con o sin especificación.

Pero hay esta impropiedad en el lenguaje legal: se habla de "bienes prendados" sin referencia a su pertenencia a conjuntos. Físicamente, es cierto, lo que acaece es la confusión, mezcla o transformación de bienes singulares. Pero desde el punto de la prenda a que se refiere el artículo 11, se trata de bienes que pertenecen a conjuntos pignorados, y no de cosas pignoradas individualmente. Así que lo importante es que los bienes confundidos, mezclados o transformados, o pertenecen a conjuntos distintos, o pertenecen a un mismo conjunto; pero en ambos casos pignorados a diferentes acreedores. En principio, la consecuencia dogmática sigue siendo la misma señalada por el artículo 11 inciso $2^{\circ}$ : el conjunto que forman los bienes generados por la confusión, mezcla o transformación empieza a quedar, de pleno Derecho, constituido en prenda. Pero, como quiera que sobre este conjunto legalmente pignorado no concurren uno, sino varios acreedores, el artículo 12 hace algunas distinciones.

b) Su supuesto general es que la combinación que fuere puede dar lugar a bienes componentes del nuevo conjunto que son, ora indivisibles, ora divisibles, se entiende que físicamente. Bajo ambos conceptos se comprenden la imposibilidad o posibilidad, tanto de la mera fracción material del bien resultante, como de la descomposición o separación de sus elementos componentes. Si, por ejemplo, se ligó cobre con estaño para formar bronce, con el que se fabricó alambre, aunque éste es divisible por fracción, pues ella no destruye al todo, y cada una de las partes resultantes sigue en su ser de alambre, no bien de menor cantidad que cuando estaban unidas en el todo, el alambre de bronce es indivisible por descomposición de sus elementos, pues la separación del cobre y del estaño destruye el bronce y el alambre. Pero si un sintonizador o radio fue instalado en cierto automóvil, la separación de ambos no destruye el automóvil ni la radio, aunque la fracción de cada uno de estos elementos destruye a los dos. Así que, desde el primer punto de vista, el automóvil es divisible en relación con su radio y ésta en relación con aquél, mientras que, desde el segundo punto de vista, ni uno ni otra es divisible. Por consiguiente, en esta materia, la divisibilidad o indivisibilidad hay que juzgarla con respecto a las cosas originalmente pignoradas y no en términos absolutos o abstractos.

c) En el primer caso, la indivisibilidad del bien resultante es suficiente para provocar sin más el efecto descrito después por la ley. En el segundo, en cambio, se necesita, además, que la efectiva división cause detrimento en el valor del bien resultante, o sea, en el todo ("de la cosa" dice el texto, con 
evidente referencia al dicho bien o todo). La ley piensa en que la división permita fraccionar o separar cada parte, elemento o pieza previamente pignorada, para que cada respectivo pignoratario ejerza sus derechos prendarios en ella, como los hubiera podido ejercer antes de la composición del bien resultante. Es menester, pues, que una tal operación acarree un detrimento en el valor de este último. La ley, por consiguiente, no atiende a un detrimento en el valor de las partes o piezas componentes, como consecuencia de la división. Pero este criterio no discierne en la mayoría de los casos, porque es evidente que una división normalmente provoca detrimento en el valor del todo, por simple aplicación del tópico de toto ad partes: un automóvil vale más con radio que sin ella; 1.000 metros de alambre valen más que 500 metros. Mejor hubiera sido acudir al criterio siempre empleado por el Código Civil cuando de separar dos cosas se trata, que va permitida si no hay deterioro en las cosas separadas o en la principal, y no en el caso contrario. En especial, recurre a él el artículo 664 CC.: "En todos los casos en que [...] pueda la primera separarse sin deterioro de lo demás [...]". La norma versa sobre la mezcla de materias y la posibilidad de separar las materias mezcladas. Ella autoriza la separación si, como dice la parte transcrita, una materia puede ser separada sin detrimento, no del valor, sino de la estructura y función de las demás mezcladas.

d) En cualesquiera de ambos casos, la ley atribuye estos tres efectos: i) las diversas prendas que gravaban los originales conjuntos de bienes componentes se conservan ("mantendrán sus derechos" dice la norma) sobre el conjunto de bienes resultantes, aunque tal vez debamos entender que se trata de una prenda nueva, porque ha cambiado el objeto; ii) pero decaen las preferencias de unas prendas frente a las otras, provenientes de la diferente antigüedad de cada pignoración, de modo de quedar cancelado el efecto previsto por el artículo 16, que, junto con autorizar la constitución de varias prendas sobre un mismo bien, establece precisadamente preferencias entre ellas, según el orden cronológico de sus respectivas inscripciones en el Registro de Prendas sin Desplazamiento; iii) como consecuencia natural de las dos reglas precedentes, los distintos acreedores concurren para el ejercicio de sus derechos prendarios en el conjunto de bienes resultantes a prorrata de sus créditos, se entiende que cuando el valor de la venta del conjunto pignorado no alcance para pagar el completo monto de todos los créditos y sus intereses, gastos y costas (artículo 15). Así que, en definitiva, la ley ordena mirar la situación como si todas las prendas hubieran sido constituidas en un mismo instante sobre el conjunto de bienes resultantes. Se tendrá presente que los acreedores de que hablamos, aunque no se prefieran entre sí, todos ellos prefieren a cualquier acreedor a favor del cual el pignorante hubiera constituido prenda posterior sobre el conjunto de 
bienes resultantes ya completamente manufacturados, cosa que siempre le fue posible hacer.

La base dogmática de esta solución es la misma que inspira la de la accesión de efectos dominicales por mezcla en el artículo 663 CC.: se forma una comunidad pro indiviso de los dueños de las cosas mezcladas sobre el todo resultante. Solo que el artículo 12 abstrae de las hipótesis subjetivas de conocimiento y mala fe recurridas en esa norma, como es natural, porque los pignoratarios no han tenido parte alguna en la operación. En materia dominical, pues, se forma la dicha comunidad. En materia de prenda también se forma una suerte de comunidad pro indiviso del derecho prendario, sólo que no pro parte rei sino pro parte crediti.

e) En la hipótesis de que los bienes resultantes sean divisibles y su división no causare detrimento en el valor de los mismos, sin atención al detrimento en el valor de las partes separadas por división, el dispositivo del artículo 12 no debe tener lugar. En tal hipótesis, pues, los distintos acreedores conservan sus prendas, con las preferencias que les dan las respectivas fechas de inscripción, sobre cada conjunto de bienes componentes originales; y no tiene lugar, por ende, la concurrencia a prorrata.

f) Se pregunta si los conjuntos originales deben ser reconformados efectivamente, merced a una real división y distribución de los bienes resultantes, de guisa que las partes divididas o separadas se subasten independientemente como tales; o si basta tener presente una división pro diviso o imaginaria, que en definitiva será contable, según las partes divisibles físicamente y valorizadas cada una, de modo que, vendido el todo no separado o dividido, los acreedores concurran según la preferencia que su prenda les dé frente a los demás, en el valor del conjunto de bienes resultantes. Supóngase que los bienes finales consistieron en ciertos computadores que fueron fabricados sobre la base de las piezas que forman el computador propiamente tal, pignorados como conjunto a uno, y de las corazas protectoras que como conjunto fueron pignoradas a otro. La máquina electrónica y su coraza protectora son separables sin detrimento recíproco, aunque el valor de una y otra sufra menoscabo, como ya advertimos. Dejando a un lado este último problema, el punto que deseamos ilustrar es el siguiente: si suponemos que el pignorante del conjunto de las piezas de las máquinas y el del conjunto de las corazas conservan sus respectivas prendas sobre el conjunto de los computadores terminados, vale decir, con integración de la máquina y la coraza, ¿̇ignifica eso que es necesario proceder a la real separación entre la máquina y sus corazas, como si se dijera que para recomponer cada conjunto, y venderlos por separado; o basta proceder a la venta de los computadores finales, completamente armados, y después hacer concurrir a los acreedores, por orden según la 
antigüedad de sus prendas, sobre el valor total conseguido? Creemos que este es un punto que debe dejarse a la voluntad de los acreedores.

g) Por último, cabe advertir que la norma del artículo 12 no fue redactada en conexión directa con las hipótesis del artículo 11, de modo de regir sólo para ellas, aunque, por cierto, las cubre. Su independencia y generalidad permite aplicarla cada vez que se diere el caso de "dos o más bienes prendados" que "se confundieren, mezclaren o transformaren", aunque no sea por las necesidades del previsto proceso productivo, que deban hacer entrar en combinación dos o más de tales bienes, sino por cualquier otra causa, incluso por accidente o caso fortuito y aún por culpa o dolo. Así, por ejemplo, si los componentes de un conjunto de trigo pignorado al acreedor A se mezclan con los componentes de un conjunto distinto de trigo, pignorado al acreedor $\mathrm{B}$, porque un terremoto destruyó las mamparas o divisiones que formaban los distintos recintos en que cada conjunto estaba depositado, el artículo 12 ciertamente tiene lugar.

7. La ley no ofrece ninguna solución especial para el segundo caso, vale decir, para aquel en que la composición del bien resultante venga dada por elementos previamente pignorados y por otros no pignorados en absoluto. Preliminarmente advirtamos, empero, que esta hipótesis aun tiene en común con la anterior el hecho de que los bienes resultantes dejan de pertenecer a los conjuntos originales de bienes componentes, de modo que, dogmáticamente hablando, la prenda de estos no alcanza al conjunto de aquéllos, que nunca fue pignorado. No se puede aplicar sin más el inciso $2^{\circ}$ del artículo 11 , que discurre sobre la base de que los bienes resultantes hayan sido totalmente formados con componentes previamente pignorados en conjunto a un acreedor; ni el artículo 12, porque ahora se funda en la hipótesis de haber sido formados con componentes pignorados a varios acreedores. Aquí se trata de que hubieran sido formados con componentes pignorados a uno y con componentes no pignorados a nadie. Así que, en principio, recobra su plena fuerza el dogma de que el conjunto de bienes resultantes no está sujeto a prenda, porque no hay una norma positiva que lo refrene, como en los casos anteriores. Lo cual es un inconveniente serio para el funcionamiento de la prenda del artículo 11, porque la hipótesis bajo estudio es muy normal en la generalidad de los procesos fabriles. Así que podemos dejarnos orientar analógicamente por los criterios del artículo 12.

De esta manera, pues, si la confusión, mezcla o transformación tuvo lugar entre componentes pignorados y no pignorados, los bienes resultantes fueren divisibles y su división no causare detrimento en el valor de éste, se puede proceder a la separación de los componentes pignorados sin más. Cuando, en cambio, los bienes resultantes fueren indivisibles, o 
divisibles, cuya división, empero, causare detrimento en el valor de aquéllos, menester es distinguir si los componentes que habían sido pignorados son principales o accesorios en el bien resultante. Si son principales, la prenda subsiste sobre todo este último, bajo el concepto de extenderse desde el bien principal a sus accesorios. $\mathrm{Si}$, por el contrario, los componentes pignorados son accesorios, se extingue la prenda.

Recurrimos, por consiguiente, a los criterios de la adjunción y la mezcla. Si los bienes resultantes derivaron de una adjunción, se aplica el artículo 658, que extiende el dominio sobre la cosa principal a la accesoria, de modo que se extingue el previo dominio de otro sobre ésta. En nuestro caso no hay cuestión de dominio involucrado, sino de una prenda. Si ésta, pues, recae sobre la cosa principal, se extiende a la accesoria. Si recae sobre la cosa accesoria, se extingue. Se recordará que, para el Código, la distinción de cosa principal y accesoria se funda en esta materia, en la diferencia importante de sus valores, de modo de ser mirada como principal la de mucho más valor (artículo 659 inciso $1^{\circ} \mathrm{CC}$.). Cuando los bienes resultantes derivaron de una mezcla, se aplica el artículo 663 inciso 2o CC.: "A menos que el valor de la materia perteneciente a uno de ellos fuere considerablemente superior, pues en tal caso el dueño de ella tendrá derecho para reclamar la cosa producida por la mezcla, pagando el precio de la materia restante". Sin decirlo, la norma mira como principal a la materia que es de valor considerablemente superior a la otra. Por ello unificamos ambos criterios desde el punto de vista de lo principal y accesorio. No consideramos la especificación, porque en ella no hay unión de dos cosas, sino de una cosa con trabajo.

8. Que la pignoración a que se refiere el inciso 2 del artículo 11 sea de pleno Derecho, o por el sólo ministerio de la ley, significa, entre otras cosas, no ser necesario un nuevo contrato prendario, referido a los bienes transformados o elaborados, que deba ser inscrito. Se trata, por supuesto, de una prenda legal. Por consiguiente, el nuevo derecho real de prenda que entonces empieza a existir no necesita de una inscripción en el Registro de Prendas sin Desplazamiento, como por regla general se exige para constituir tal derecho ${ }^{63}$. Esta consecuencia deriva, como decimos, de la naturaleza legal de la prenda establecida por el inciso $2^{\circ}$ del artículo 11 , pues siendo la ley el título o fuente de dicha prenda, no cabe pedir su inscripción, ni está dicho que así deba hacerse.

Pero sí es necesario demostrar que los nuevos bienes transformados o elaborados provienen de los bienes componentes del grupo o universalidad

${ }^{63}$ Cfr. el inciso $2^{\circ}$ del artículo 25 de la derogada Ley No 5.687 sobre contrato de prenda industrial (DO. de 17 de septiembre de 1935): "La prenda establecida sobre la materia prima, quedará ipso iure constituida sobre el producto elaborado, tan pronto aquella fuere elaborada o manufacturada”. 
convencionalmente pignorados en su día. Esta regla deriva del texto legal, el cual, en efecto dice: "Los bienes transformados [...] asi como el producto elaborado con los componentes de dichas existencias, quedarán de pleno Derecho constituidos en prenda". Él exige, pues, que la transformación o elaboración haya sido "con los componentes" del conjunto pignorado. En consecuencia, si una u otra fue con componentes de conjuntos no pignorados, la prenda legal no puede tener lugar. Lo cual es muy natural.

9. Pero, con ser natural, crea problemas teóricamente de difícil solución para el pignoratario. Para éste, el asunto constituye una cuestión de hecho cuya carga de prueba le corresponde, de acuerdo con las reglas generales, porque él es quien habrá de sostener la existencia de un derecho real de prenda sobre tal cosa, en este caso, sobre el conjunto de los bienes transformados o elaborados. La ley omitió ayudarlo, por ejemplo, con presunciones que alteraran esa carga, tal cual ocurriría si, sobre la base de una descripción en el contrato prendario, no sólo del grupo o universalidad pignorados, más también de los previstos bienes transformados o elaborados a partir de sus componentes, se hubiese declarado presumirse legalmente transformados o elaborados con dichos componentes, todos los bienes que se encontraren en las bodegas o en los depósitos del pignorante, y que obedecieren a la descripción anticipada en el contrato; así que correspondiera al pignorante demostrar que la transformación o elaboración fue con elementos de conjuntos no pignorados.

En tales circunstancias, el resguardo de la integridad y consistencia de la prenda legal de que tratamos dependerá de una cuidada construcción del contrato prendario, en orden a insertarle cláusulas de control por medio de contabilidades especiales o generales, de vigilancia física de los procesos fabriles y de declaraciones periódicas del pignorante acerca del destino de los componentes de los conjuntos pignorados, debidamente sancionadas con sendas cláusulas de aceleración del pago de la deuda garantizada en caso de contravención. Cautelas de este género y de otros, permiten al acreedor preconstituirse pruebas por si llegare el caso de tener que ejercer sus derechos prendarios sobre los conjuntos de bienes transformados o elaborados.

En todo caso, no debe olvidarse que el pignorante puede cometer el delito tipificado por el No 2 del artículo 39, el cual dice cometerlo: " $E l$ deudor prendario y el que tenga en su poder la cosa constituida en prenda en conformidad a esta ley que, defraudando al acreedor prendario, la altere, oculte, sustituya, traslade o disponga de ella". En este delito, en efecto, puede incurrirse con una conducta que consista en disimular que tales o cuales bienes transformados o elaborados lo fueron con elementos que estaban pignorados como conjunto. 
10. La construcción que se desprende del inciso $2^{\circ}$ del artículo 11 plantea un problema relativo a los bienes transformados o elaborados. Si la prenda de pleno Derecho de que habla esa disposición es una prenda nueva y distinta de la originalmente constituida sobre el grupo de bienes o universalidad de hecho a que pertenecieron los componentes después transformados o elaborados; si ella carece de un contrato nuevo que establezca su régimen; y si también carece de una nueva inscripción en el Registro de Prendas sin Desplazamiento, resulta entonces que está privada de una fecha cierta o fácilmente certificable, puesto que los bienes transformados, como que son productos de un proceso fabril que suele extenderse en el tiempo, empiezan a existir en momento difícilmente determinables y, además, en diferentes tiempos cada especie singular. Teóricamente, sin embargo, el asunto se plantea así: cada singular bien transformado empieza a quedar en prenda por el sólo ministerio de la ley en el instante mismo en que es terminado. Ahora bien, la fijación de ese instante es cuestión de hecho. Mas, como la terminación hace nacer un estado permanente hacia el futuro, que podemos denominar de "terminación", resulta que de todos los bienes transformados o elaborados que en cualquier momento existan como terminados, por ejemplo, en una bodega o almacén, se puede decir que están pignorados. Así que el asunto se reconduce a meramente probar la existencia actual de una partida de bienes terminados a partir de la transformación de los componentes de un grupo o universalidad pignorados; de guisa que, probada tal existencia y derivación, deba concluirse que esa partida está también pignorada. Esto no es una presunción legal, que exigiría norma expresa, sino simplemente judicial.

En cuanto a la inexistencia de un contrato regulador de la nueva prenda, lo que puede ser perjudicial para el pignoratario, ello hace aconsejable prever un régimen para los bienes transformados en el contrato original. En el resto, como éstos quedan de todos modos pignorados de pleno Derecho, todas las normas imperativas y prohibitivas de la Ley No 20.190 en materia de prenda sin desplazamiento son aplicables sin más a tales bienes. Así, por ejemplo, el pignorante puede cometer los delitos de su artículo 39 con respecto a ellos. Pero también las permisivas, de modo que, por ejemplo, el pignorante puede enajenar los bienes transformados, en uso de la autorización genérica del inciso $1^{\circ}$ del artículo 11. Sólo que, en tal caso, la enajenación empieza a hacer aplicable el inciso $3^{\circ}$, que ahora pasamos a estudiar.

XIII. SUBROGACIÓN PRENDARIA EN CASO DE ENAJENACIÓN DE LOS COMPONENTES DE UN GRUPO O UNIVERSALIDAD PIGNORADOS

El inciso 3o del artículo 11 expresa: "Aquellos componentes que salgan de la universalidad o grupo de bienes empeñados quedarán subrogados por 
los que posteriormente lo integren, hasta la concurrencia del total constituido en prenda".

1. La disposición supone una pignoración perfeccionada sobre cierto grupo de bienes de la misma clase o universalidad de hecho, que, en consecuencia, está integrada por "componentes", con la cual voz aquélla designa las especies singulares integrante del grupo o universalidad de que se trata. Sobre esta base, se sitúa en la hipótesis de que algunos, muchos o incluso todos dichos componentes -cuya cantidad, en efecto, la ley no distingue- "salgan" del grupo o universalidad que una vez fue objeto de cierta pignoración.

a) Con el uso del verbo "salgan", la norma mienta, en primer lugar, la enajenación de los componentes del grupo de bienes o universalidad de hecho pignorados ("empeñados", dice el artículo), a cualquier título que sea. Lo ordinario será que la enajenación sea aquella que hace parte de un proceso comercial de ventas normales; pero podría deberse a otras razones, por ejemplo, a donaciones o aportes para ciertas obras de caridad o ayuda a zonas devastadas por catástrofes naturales, e, incluso, para acciones no institucionales, sino privadas o esporádicas del pignorante.

El mismo verbo es apto para incluir la salida de componentes debida, no ya a enajenación, sino a mermas naturales causadas en el transcurso del tiempo o a la acción de agentes externos, a vicios ocultos, a hurtos o robos sufridos, a destrucciones o inutilizaciones provocadas por accidentes, como incendios, atentados, terremotos o huracanes y similares.

Acerca de si las "salidas" abrazan también las causadas por la necesidad de emplear los componentes en el proceso productivo normal, trataremos más adelante por separado ${ }^{64}$.

b) La ley supone que con posterioridad a la salida de componentes siga una suerte de entrada de otros objetos. Expresa así esta idea: "los que posteriormente lo integren", en donde "los" está por "los componentes", pero con una leve impropiedad, pues los objetos que empiecen a integrar el conjunto pignorado no son componentes que vienen desde afuera como tales, sino que empiezan a ser componentes sólo desde el momento en que lo integren. Por su parte "lo" está por "la universalidad o grupo de bienes". Así que, en final de cuentas es claro que la norma se refiere a objetos que empiezan a integrar el mismo conjunto del cual antes salieron ciertos componentes suyos y que, por ende, desde ese momento empiezan a ser nuevos componentes también suyos.

Pero nada dice la norma acerca de la cualidad de estos nuevos componentes. El punto se refiere a si ellos deben pertenecer al mismo género al

${ }^{64}$ Véase, más abajo, el capítulo XIV, 1. 
que pertenecían los componentes salidos, o si pueden pertenecer a géneros distintos. Supongamos que de la existencia pignorada de 100 barriles de petróleo, salieron 60 de ellos y que después ingresaron 30 barriles de bencina a bodegas. Se pregunta si estos últimos quedan cubiertos por la norma en examen. La respuesta es negativa. Si, en el ejemplo, la universalidad o grupo de bienes pignorados estaba constituida por barriles de petróleo, no hay manera de aceptar que unos barriles de bencina integren la universalidad o grupo de barriles de petróleo de los que salieron algunos de ellos, en circunstancias que, como acabamos de ver, la ley habla de "los que posteriormente lo integren", vale decir, de que nuevos objetos integren el mismo grupo o universalidad del cual antes habían salidos algunos de sus componentes. De aceptarse una respuesta positiva, se llegaría a esta enorme y absurda consecuencia: que el dispositivo del inciso $3^{\circ}-$ la subrogación prendaria de que hablaremos-operaría automáticamente y sin más, cada vez que ingresare un nuevo objeto del género que sea a existencias, inventarios, etc., por el sólo hecho de haber una prenda constituida sobre cualquiera de tales existencias, inventarios, etc.

Así que concluimos que la figura establecida por el inciso $3^{\circ}$ exige que el bien que ingresa debe pertenecer al mismo género de componentes de algún conjunto pignorado. Por supuesto que el juicio acerca de la identidad o diversidad de los géneros de objetos de que hemos hablado dependerá del modo en que originalmente se construyó el género o clase de cosas o la universalidad al constituirse la prenda. Si rectificamos el ejemplo anterior, en el sentido de que la prenda había recaído sobre 100 barriles, no de petróleo, sino de combustible líquido, y el conjunto estaba integrado por barriles de petróleo, bencina y parafina, los 60 barriles de petróleo salidos ahora sí pueden ser reemplazos por la entrada de 30 barriles de bencina, porque estos también pertenecen al género "barriles de combustible líquido".

Como puede advertirse, el punto que acabamos de examinar es el mismo que estudiamos antes, a propósito de la facultad que tiene el pignorante de reemplazar los componentes de un conjunto pignorado, de acuerdo con el inciso $1^{\circ}$ del artículo $11^{65}$. En efecto, lo que ese inciso mienta sintéticamente con el verbo "reemplazar" es lo mismo que el inciso $3^{\circ}$ describe analíticamente con la operación de salida e integración (entrada) de bienes.

2. Sobre todo como contrapartida de la autorización concedida al pignorante en el inciso 1 del artículo 11 , en orden a enajenar los componentes de un grupo de bienes o universalidad de hecho pignorados, su

${ }^{65}$ Véase, más arriba, el capítulo XII, 1. 
inciso $3^{\circ}$ establece la que llamaremos subrogación prendaria, aunque no sólo procede en caso de enajenación, como antes vimos. Aquella viene, pues, a consistir en que las cosas pertenecientes al mismo género al que pertenecían los componentes salidos de un grupo o universalidad pignorados, que con posterioridad ingresen en el patrimonio del pignorante, empiezan a ocupar la posición que los salidos tenían en él a efectos de la prenda, vale decir, empiezan a quedar pignorados también.

a) Se observará, en consecuencia, la diferencia de efectos atribuidos por la ley a las hipótesis del inciso $2^{\circ}$, que es el de una nueva prenda, y del inciso $3^{\circ}$, que es el de una subrogación en la prenda. En común tienen, empero, ambas figuras su operación por el ministerio de la ley: en el caso previsto en el inciso 2, eso está dicho expresamente merced al empleo de la expresión "de pleno Derecho"; en el caso del inciso $3^{\circ}$, en cambio, no está dicho en forma expresa; pero como la subrogación tiene lugar precisamente porque ese inciso la establece, el intérprete puede declarar muy naturalmente que la subrogación prendaria de que ahí se trata es por el ministerio del citado inciso, lo cual equivale a decir que es también de pleno Derecho. En todo caso, está claro que no se trata de una subrogación convencional, como tampoco es convencional la legitimación del pignorante para enajenar los componentes del grupo o universalidad pignorados, pues deriva del inciso $1^{\circ}$ del artículo 11. Así, pues, a la autorización legal de enajenar corresponde simétricamente la subrogación legal de lo enajenado.

Ahora bien, que en el inciso $3^{\circ}$ se trate de una subrogación y no de una nueva prenda, tiene esta consecuencia: la pignoración de los nuevos componentes del grupo o universalidad pignorados queda amparada en el todo por el contrato prendario original, de modo que las mismas condiciones fijadas en él son aplicables sin más a los componentes subrogantes; y también queda amparada por la inscripción del mismo en el Registro de Prendas sin Desplazamiento y por su fecha; todo ello, aunque nada se haya dicho en tal sentido en el contrato original. Esta consecuencia deriva, en efecto, de las reglas generales que rigen la subrogación de bienes en cualquier ámbito.

b) Conviene acentuar que el efecto subrogatorio sólo tiene lugar si es que previamente al ingreso de un nuevo bien u objeto, el conjunto pignorado sufrió alguna salida. Si precedentemente al ingreso de nuevos componentes, pues, no se había producido ninguna salida, no procede aplicar el inciso $3^{\circ}$. Así que cuando, por ejemplo, a una existencia original de 50.000 sacos de cemento pignorada se le añaden 30.000 más en el momento en que la existencia original estaba intacta, este añadido no queda pignorado.

Esta es una limitación a las potencias de la doctrina sobre la universalidad de hecho. Porque, en efecto, si lo pignorado fue una tal univer- 
salidad, el ingreso de nuevos componentes en ella, aunque no sea como contrapartida de una previa salida de los mismos, hace que dichos nuevos componentes queden cubiertos por la prenda. Aun más, no se trata de una subrogación, porque el objeto pignorado sigue siendo el mismo. Pero los términos del inciso $3^{\circ}$ obligan a considerar alterado este dogma, en orden a ver una subrogación y a limitarla al caso de operar como contrapartida de una salida.

c) La subrogación no padece límites en cuanto al número de veces que puede tener lugar y se reitera indefinidamente, pues, toda vez que ocurran salidas seguidas de ingresos de nuevos componentes. En efecto, la subrogación que tuvo lugar merced a una primera salida de componentes seguida de un ulterior ingreso de nuevos componentes, dejó pignorados a estos últimos; cuando tiene lugar una segunda salida de componentes, que necesariamente estaban pignoradas, y sigue un segundo ingreso de nuevos componentes, la situación que entonces se configura coincide perfectamente con la descrita por el inciso $3^{\circ}$. Por lo demás, desde un punto de vista literal, el adverbio "posteriormente" empleado en dicho inciso comprende a todos los ingresos que acaecen después de la primera salida y no sólo al primero.

d) Pero la subrogación opera con un límite cuantitativo. El inciso $3^{\circ}$ del artículo 11 dice: "[...] quedarán subrogados por los que posteriormente lo integren, hasta la concurrencia del total constituido en prenda". La expresión "total" significa el "total de componentes" originalmente constituido en prenda. De esta manera, los nuevos componentes que excedan a este total no quedan pignorados. Así que, por ejemplo, cuando una empresa automotora hubiera pignorado un grupo de 100 automóviles en existencia y vendido 60 de ellas, que posteriormente reemplaza por 150 más, de esta última partida solo 60 automóviles subrogan prendariamente a los 60 salidos antes, y los 90 excedentes permanecen libres de gravamen. Lo que nuevamente constituye una limitación al régimen normal de las universalidades de hecho.

Pero se pregunta si, dado el caso de un exceso de nuevos componentes, no subrogante por ende, tiene lugar una nueva salida de componentes no seguida de un ingreso de otros tales, el exceso original empieza a subrogar o no a los salidos. Supongamos que, en el ejemplo precedente, después de ingresados los 150 nuevos automóviles, la empresa pignorante vendió otros 40 (que estaban pignorados) y no los reemplazó: ‘acaece que 40 de los 90 que antes no habían quedado pignorados por subrogación, pues excedieron a los 100 originalmente dados en prenda, empiezan ahora a quedar bajo el gravamen por subrogación de los 40 nuevamente salidos? La letra del inciso $3^{\circ}$ parece apoyar la respuesta negativa: "aquellos compo- 
nentes que salgan de la universalidad o grupo de bienes empeñados quedarán subrogados por los que posteriormente lo integren": en efecto, los componentes en exceso no integraron el conjunto pignorado "posteriormente" a la salida de aquellos de cuya subrogación se trata, sino antes de su salida. La consecuencia, siempre en el ejemplo, es que la prenda queda reducida a 60 automóviles y los 90 restantes siguen libres de esa carga. Si la empresa vende los primeros, ésta se reduce a cero, por más que la actual existencia monte todavía a 90 unidades.

Pero un análisis dogmático de la situación, que no deja de estar apoyado en otra lectura del inciso $3^{\circ}$, conduce a la respuesta positiva.

En cuanto, pues, el artículo 11 trata de la prenda de universalidades de hecho y no de bienes singulares; o, si se prefiere, de bienes singulares, pero sólo en cuanto forman parte de cierta universalidad, la inmutabilidad que es propia de estos conjuntos, en cuanto la variación de sus componentes no altera la consistencia del conjunto total, la pignoración de éste afecta a todos los nuevos componentes que ingresen en él con posterioridad a la pignoración. Ahora bien, la ley limita este efecto al sólo caso que el ingreso sea la contrapartida de una salida, como antes vimos; pero como nada dice sobre la hipótesis que ahora estudiamos, debemos volver a la doctrina general de las universalidades y aceptar que los componentes ingresados que no quedaron pignorados por no corresponder a una salida previa, sí subrogan a los salidos después de su ingreso. En cuanto a la letra del inciso 30: "aquellos componentes que salgan de la universalidado grupo de bienes empeñados quedarán subrogados por los que posteriormente lo integren", esta otra lectura apoya la precedente conclusión: en efecto, aunque los componentes en exceso no integraron el conjunto pignorado "posteriormente" a la salida de aquellos de cuya subrogación se trata, sí integraron la universalidad o grupo "posteriormente" a su pignoración, y esta posterioridad en términos absolutos es suficiente para aceptar que queden cubiertos por la prenda, aunque temporalmente esto no haya acaecido, por causa del límite cuantitativo establecido seguidamente en la misma disposición.

\section{CONCURRENCIA DE LA CONSTITUCIÓN LEGAL DE UNA NUEVA PRENDA SOBRE BIENES TRANSFORMADOS Y PRODUCTOS ELABORADOS Y SUBROGACIÓN PRENDARIA}

En este capítulo trataremos de la eventual concurrencia de las hipótesis de los incisos $2^{\circ}$ y $3^{\circ}$ del artículo 11 .

El inciso $2^{\circ}$ de ese artículo configura, como se recordará, una prenda legal nueva sobre conjuntos de bienes que fueron obtenidos por transformación en otros que formaban parte de cierto conjunto originalmente 
pignorado, que llama "bienes transformados"; y sobre conjuntos de productos nuevos, que fueron elaborados con componentes provenientes de otro conjunto previamente pignorado. Por su parte, el inciso $3^{\circ}$ establece la subrogación prendaria de los componentes salidos de un conjunto pignorado, por los nuevos componentes ingresados en él. Las hipótesis son, en principio, distintas; pero es posible que entren en concurrencia. $\mathrm{Al}$ respecto, pueden darse dos tipos de concurrencia.

1. Acontece que, además de otros casos, como por ventas normales, hurtos, donaciones, etcétera, los componentes de un conjunto pignorado también "salen" de él cuando se los destina, como es normal, al proceso fabril, que conduce, ora a su transformación en otros bienes, ora a su integración con otros bienes, que da por resultado un nuevo bien. Por otro lado, cuando ello acaece, es normal que se reponga los componentes salidos para la operación fabril con otros similares, en función de mantener la continuidad de dicho proceso. Ahora bien, de acuerdo con el inciso $2^{\circ}$, el producto fabril -llamémosle así- queda constituido de pleno Derecho en prenda; pero, de acuerdo con el inciso $3^{\circ}$, los nuevos componentes del conjunto pignorado, ingresados en él para reponer los que salieron en dirección al proceso, también quedan pignorados. De esta concurrencia de hipótesis resultaría pues, una concurrencia de prendas: sobre el producto fabril y sobre los nuevos componentes; así que el pignorante vería aumentada su carga y el pignoratario incrementado su beneficio prendarios.

Tal vez sea útil un ejemplo: supóngase una prenda sin desplazamiento sobre ciertas existencias de lingotes de cobre, que fueron fijadas en 100 unidades con un valor de 1.000 la unidad, para garantizar una deuda de 100.000. El empresario, por cualquier razón, vende 10 unidades y emplea 70 en la fabricación de 500 rollos de cañería de cobre (cuya fabricación es su giro), con valor de 100 el rollo. Entretanto, adquiere 80 lingotes nuevos iguales a los "salidos" antes. La situación se presenta así: merced al inciso $2^{\circ}$, los 500 rollos, que en total valen 50.000 , quedan de pleno Derecho en prenda a título de bienes transformados; en virtud del inciso $3^{\circ}$, los 80 lingotes posteriormente adquiridos, que en total valen 80.000 se subrogan pignoraticiamente a los 80 "salidos"; en fin, la prenda sobre los 20 lingotes que aun permanecen en bodegas se mantiene inalterada. Por consiguiente, el pignorante soporta ahora una prenda antigua sobre los 20 lingotes en bodega, por 20.000; una prenda nueva sobre los 500 rollos, por 50.000; y una prenda subrogante sobre los 80 lingotes nuevamente comprados, por 80.000 ; vale decir, soporta prendas por bienes que valen 150.000 para garantizar la inalterada deuda de 100.000 (dejemos a un lado los intereses), en circunstancias de que originalmente la prenda para la misma deuda fue por bienes que valían 100.000. 
Esto podría parecer inequitativo; pero no lo es a la luz del principio de indivisibilidad de la prenda (artículos 2405 y 2396 inciso $1^{\circ}$ CC.), válido en materia de prenda sin desplazamiento, merced al artículo 1 de la nueva ley, que no ha modificado o limitado para ella, salvo en un punto, pues la parte final del inciso $3^{\circ}$ dice que la subrogación es "hasta la concurrencia del total constituido en prenda", con lo cual, como vimos, alude hasta el total de los componentes del grupo o universalidad originalmente pignorados. Así que, en el ejemplo, si suponemos que el empresario, en vez de reponer los 80 lingotes "salidos" con otros tantos, los reemplazara por 150, $80 \mathrm{de}$ estos quedarían pignorados junto a los 20 que no "salieron", para mantener el total de 100 constituido originalmente en prenda.

2. Pero también debemos estudiar otra forma de concurrencia, que plantearemos a través de un ejemplo. Supóngase que hay cierta prenda sobre un conjunto de 1.000 barras de cobre; con 500 de las cuales el pignorante fabrica 50.000 metros de cable. De acuerdo con el inciso $2^{\circ}$ del artículo 11 , ese cable queda bajo una nueva prenda legal. Si las restantes 500 barras de cobre son vendidas y después ingresan otras 500 , en conformidad con el inciso $2^{\circ}$ del mismo artículo estas últimas subrogan a aquéllas en la prenda original. Todo esto ya fue objeto de examen. Se pregunta ahora si los 50.000 metros de cable legalmente pignorados que fueron, empero, vendidos resultan subrogados en la prenda legal que los gravaba por cierta partida 25.000 metros de cable de cobre que el pignorante adquiere posteriormente. Ahora podemos generalizar el problema, que consiste, pues, en saber si la subrogación prevista en el inciso $3^{\circ}$ del artículo 11 se aplica o no a los bienes transformados o elaborados que, según el inciso $2^{\circ}$, empiezan a quedar legalmente pignorados.

La respuesta es aparentemente negativa. Esa disposición dice: "Aquellos componentes que salgan de la universalidad o grupo de bienes empeñados quedarán subrogados por los que posteriormente lo integren, hasta la concurrencia del total constituido en prenda". Con la expresión "salgan de la universalidad o grupo de bienes empeñados" la norma parece mentar la salida de la universalidad o grupo originalmente pignorados merced al contrato prendario inscrito; y ello excluye a los bienes transformados y a los productos elaborados, cuya pignoración proviene, no de ese contrato, sino de la ley, o sea, del inciso $2^{\circ}$ del artículo 11.

Pero una atención dogmática del asunto, completada por otra lectura de la letra legal, permite llegar a una respuesta positiva.

En efecto, la prenda tratada por el artículo 11 supone, como un hecho, el completo dinamismo y la permanente mudanza del contenido de los conjuntos pignorables de que trata, que son asumidos y aceptados por la ley. Ahora bien, los bienes transformados y los productos elaborados ofrecen 
el mismo dinamismo y la misma mudanza; de donde que no se perciba alguna razón para impedir que también en ellos opere la subrogación. Así que la expresión "salgan de la universalidad o grupo de bienes empeñados" podemos interpretarla, no como referente a una salida de la universalidad o grupo originalmente pignorados en virtud del contrato inscrito, mas como referente a ambas, por cierto, y también a la universalidad o grupo formado por los bienes transformados y los productos elaborados. Claro es que esta subrogación opera con el límite que establece el inciso $3^{\circ}$, vale decir, "hasta la concurrencia del total constituido en prenda". En la hipótesis, el "total constituido en prenda" es, por cierto, el total de la prenda legal, no el total original de origen contractual. En el ejemplo con que iniciamos la discusión del presente tema, ese total viene a ser la cantidad de 50.000 metros de cable fabricados; así que, en el mismo ejemplo, la subrogación opera en la partida posteriormente adquirida de 25.000 metros de cable. Si la adquisición hubiera sido de 60.000 metros, la subrogación quedaría limitada a 50.000 .

\section{PURGA DE LA PRENDA \\ DE LOS BIENES ENAJENADOS Y REEMPLAZADOS}

Hemos visto que, de acuerdo con el inciso $1^{\circ}$ del artículo 11 , los componentes de los grupos de bienes o universalidades de hecho pignorados pueden ser, además de utilizados y transformados, también reemplazados o enajenados, en todo o en parte (salvo pacto en contrario). Como contrapartida, el inciso $2^{\circ}$ declara pignorados por el sólo ministerio de la ley los bienes transformados y los productos elaborados con los componentes del conjunto que estaba en prenda convencional; y el inciso $3^{\circ}$ subroga en la prenda a los componentes de dichos conjuntos salidos por los nuevos componentes que empiecen a integrarlos.

Ahora bien, sobre todo en el caso de enajenación de componentes del conjunto pignorado, pero también en el de su reemplazo, debemos pensar que los componentes enajenados y los reemplazados dejan de estar en prenda. Supóngase que un empresario pignora un grupo de 100 automóviles, de los cuales vende 30 . Lo que afirmamos es que la prenda que gravaba al grupo no se mantiene con respecto a cada una de estas 30 unidades vendidas, de modo que quien las adquiera, las adquiere libres de gravamen; y podríamos hablar, pues, de una suerte de purga de la prenda; así que el pignorante ya no podría perseguir las dichas unidades, porque carece de un derecho prendario real a su respecto. Lo propio acaece si algunos de los automóviles son reemplazados por otros debido a la causa que sea: los reemplazados quedan libres de prenda, no bien los reemplazantes los subroguen en ella. Todo esto es efecto natural y normal del dogma de la 
universalidad de hecho: los bienes enajenados y reemplazados, por la circunstancia de su enajenación o reemplazo, han dejado de pertenecer a la que fue pignorada; por consiguiente la prenda que la afectó y sigue afectándola, no puede irradiar a unos elementos que ya no la componen.

La ley nada dice acerca de este punto. Mas no por ello puede derivarse una conclusión contraria a la antes expuesta, que sería ilógica. En efecto, si la prenda no se extinguiera en las circunstancias dichas, deberían tener lugar varios efectos: i) la garantía prendaria se incrementaría indefinidamente, pues a la que cubre los bienes originalmente pignorados presentes, a la vigente sobre los bienes transformados y los elaborados, y a la que afecta a los subrogantes, se ańadiría la permaneciente sobre los enajenados y los reemplazados; teniendo presente que esta última adición prendaria puede repetirse muchas veces; ii) la prenda afectaría a objetos que ya no pertenecen al conjunto pignorado; y iii) dejaría de tener sentido la figura de la subrogación, cuyo efecto preciso es extraer a un bien de cierto estatuto porque otro, que lo reemplazó, ingresó en él; vale decir, no habría subrogación.

\section{INDIVIDUALIZACIÓN DEL CONJUNTO PIGNORADO}

1. El artículo 3 No 3 de la ley obliga a mencionar - "deberá contener" dice-: "La individualización o la caracterización de las cosas empeñadas" en el contrato escrito.

a) Este imperativo parece venir contradicho por el artículo 11 inciso 4o: "Cuando se pignoraren universalidades o grupos de bienes en la forma señalada en el inciso primero, el contrato de prenda deberá indicar el valor del conjunto de bienes sobre los que recaiga la prenda, salvo que las partes acuerden expresamente no asignarle un valor. En este último caso, no será aplicable lo dispuesto en el artículo 1496, $N^{\circ} 2$, del Código Civil y el contrato de prenda deberá señalar las particularidades tendientes a individualizar los bienes prendados, señalando si son fungibles o no, determinando en el primer caso su especie, cantidad, calidad, graduación y variedad".

La primera parte del inciso ordena indicar el valor del conjunto de bienes pignorado, salvo que las partes acuerden no asignarle valor $-\mathrm{y}$ a todo ello nos referiremos después ${ }^{66}$ - . Pero “en este último caso"-dice la segunda parte-, vale decir, en aquel en que los contratantes acordaron no indicar el valor del conjunto gravado, se hace inaplicable el artículo 1496 No 2 del Código Civil-y también trataremos después el punto ${ }^{67}$. Ahora bien, esa

${ }^{66}$ Véase, más abajo, el capítulo XVIII.

${ }^{67}$ Ibíd. 
segunda parte continúa inmediatamente así: "y el contrato de prenda deberá señalar las particularidades tendientes a individualizar los bienes prendados $\left[\ldots .\right.$. ", etcétera. Por consiguiente, la letra de la segunda parte del inciso $4^{\circ}$ permite entender que sólo cuando las partes acordaron expresamente no asignarle un valor al conjunto pignorado, vale decir, "en este último caso", se siguen los efectos de no ser aplicable el artículo 1496 No 2 CC. "y" de sí deberse señalar las particularidades tendientes a individualizar los bienes prendados, etcétera. De lo que se podría concluir que cuando las partes asignaron valor a tal conjunto, ahora es aplicable la mencionada disposición del Código y no existe el deber de señalar las particularidades tendientes a individualizar los bienes prendados, etcétera. Es una conclusión aparentemente necesaria de la secuencia: "En este último caso, no será aplicable [...] y el contrato de prenda deberá señalar las particularidades [...]", porque la expresión "en este último caso" rige las dos oraciones sucesivas que empiezan por "no será aplicable" y por "el contrato de prenda deberá", ambas unidas con la conjunción " $y$ ".

b) Pero esta lectura, que conduce a la alternativa entre señalamiento de valor o descripción, no da un sentido inteligible y claro al inciso $4^{\circ}$, en cuanto a que si las partes fijaron un valor para el conjunto pignorado, no es necesario señalar las particularidades tendientes a individualizar los bienes que fueron objetos del pertinente contrato, de guisa de constituir una excepción al artículo 3 No 3 , citado al principiar, porque, en efecto, no se percibe una razón suficiente para tal excepción y porque la ausencia de individualización del conjunto pignorado introduce tales problemas de aplicación, que lo tornan en impracticable e inejecutable.

A esto último nos referiremos después. Por ahora será suficiente demostrar que la letra con que aparece compuesta la segunda parte del inciso $4^{\mathrm{o}}$ se debe -una vez más- a una inadvertencia del legislador. Al efecto, compararemos el texto de la norma tal cual compareció en una primera indicación sustitutiva del Ejecutivo, como se revela en el "Informe de la Comisión de Constitución, Legislación y Justicia”, de la Cámara de Diputados, el texto aprobado por dicha Comisión y el texto legal final (debido a una segunda indicación sustitutiva presentada por el Ejecutivo en el Senado), según se ve a continuación: 


"Texto de la primera
indicación sustitutiva del
Ejecutivo, artículo 12
inciso $4^{68}$

1 "Cuando se pignoraren

2 existencias

3 en la forma señalada en el inciso primero de este artículo, el contrato deberá indicar el valor del conjunto de bienes sobre los que recaiga la prenda.

4 Lo anterior es sin perjuicio que las partes acuerden no asignarle valor a la universalidad,

5 caso en el cual

6 no será aplicable lo dispuesto en el artículo 1496, № 2 del Código Civil,

7 pero

8 la universalidad deberá ser señalada y determinada en forma inequívoca".
Texto aprobado por la Comisión de Constitución, Legislación y Justicia de la Cámara de Diputados"69

"Cuando se pignoraren existencias

en la forma señalada en el inciso primero de este artículo, el contrato deberá indicar el valor del conjunto de bienes sobre los que recaiga la prenda.

Sin perjuicio de lo establecido en el inciso anterior, si las partes acuerdan no asignarle valor a la universalidad, caso en el cual

no será aplicable lo dispuesto en el artículo 1496 NN$^{\circ} 2$ del Código Civil,

esa universalidad deberá ser señalada y determinada en forma inequívoca”.
Texto de la Ley No

20.190, artículo 11

inciso $4^{\circ}$

\begin{abstract}
"Cuando se pignoraren universalidades o grupos de bienes

en la forma señalada en el inciso primero, el contrato de prenda deberá indicar el valor del conjunto de bienes sobre los que recaiga la prenda,

salvo que las partes acuerden expresamente no asignarle un valor.
\end{abstract}

En este último caso, no será aplicable lo dispuesto en el artículo 1496, N 2, del Código Civil

y

el contrato de prenda deberá señalar las particularidades tendientes a individualizar los bienes prendados, señalando si son fungibles o no, determinando en el primer caso su especie, cantidad, calidad, graduación y variedad".

El texto de la primera indicación sustitutiva del Ejecutivo, que no existía en el proyecto originalmente presentado por él, empleaba en su primera parte (líneas 1 a 3) dos conceptos: existencias y conjunto de bienes. Probablemente se mentaba lo mismo: las existencias, porque a ellas se refería el inciso $1^{\circ}$ del artículo 12 . Por consiguiente, en su primera parte, el inciso mandaba indicar el valor del conjunto de bienes, vale decir, de la existencia, pignorado. La segunda parte (línea 4) ofrecía una extraña redacción:

\footnotetext{
${ }^{68}$ Historia, p. 297

${ }^{69}$ Historia, p. 313.
} 
comenzaba con: "Lo anterior es sin perjuicio", en circunstancias que decía todo lo contrario de lo expresado en la primera parte, así que no era "sin perjuicio de lo anterior" mas "con perjuicio de lo anterior"; y sentaba, pues, la regla de que las partes podían no asignar valor a la "universalidad", con lo cual añadía un tercer concepto, pero que probablemente también mentaba a la existencia pignorada. La indicación continuaba con una tercera parte, integrada por los textos de las líneas 5 y 6 ; y finalizaba con una cuarta parte (líneas 7 y 8), introducida por otra frase adversativa ("pero") que ordenaba señalar y determinar inequívocamente la universalidad. Esta última frase carecía de toda justificación, pues infiltraba un tema extraño: la disposición venía hablando sobre la indicación del valor de lo pignorado, y con ello nada tiene que ver su individualización, tema, por lo demás, resuelto en el general artículo 3, que ordena hacerla. Tal vez el redactor de la indicación pensó que la autorización para no indicar el valor de la existencia gravada pudiere interpretarse como una licencia para tampoco individualizarlas; de donde la preposición adversativa "pero" usada, para reafirmar la idea contraria. Ahora bien, si se elimina del inciso la frase que empieza con "pero" (línea 7), como cuerpo extraño en él, de modo de hacerlo llegar hasta "Código Civil" (línea 6), ahora contiene unas ideas perfectamente inteligibles, sobre la base de que el tema de la individualización ya estaba resuelto antes, en el artículo 3.

En el texto aprobado por la comisión, el asunto cambió su perspectiva: el cuerpo extraño que era la idea de la frase con "pero" del texto anterior (línea 6), pasó a ser la prescripción de la norma que empieza con "Sin perjuicio" (línea 4), porque ella se lee así: "Sin perjuicio de lo establecido en el inciso anterior, si las partes acuerdan no asignarle valor a la universalidad [...] esa universalidad deberá ser señalada y determinada en forma inequívoca". La frase relativa al artículo $1496 \mathrm{~N}^{\circ} 2$ del Código Civil es sólo una intercalación. El texto de la ley (debido a una segunda indicación sustitutiva del Ejecutivo en el Senado) mejoró la redacción de la primera parte del inciso (líneas 1 a 4) (y cambió su nomenclatura); pero vigorizó la dependencia de la individualización con respecto al caso de no asignarse valor a lo pignorado, cuando creó un punto aparte cuya hipótesis se inicia precisamente con la expresión "En este último caso" (línea 5), de modo de venir a afirmarse, en síntesis, que en ese caso, vale decir, sólo en él, no se aplica el artículo 1496, $\mathrm{N}^{\circ} 2$ del Código Civil y sí debe individualizarse lo pignorado como ahí se dice. De esta forma, la idea que inicialmente estaba motivada nada más que por la cautela, aunque innecesaria, de recordar, para el caso de no indicarse el valor, una regla de todos modos aplicable, devino en la idea de una regla sólo válida para ese caso.

Pero esto no es así. La idea de individualización de lo pignorado es 
esencial, sea que se indique el valor del grupo de bienes o universalidad de hecho pignorados, sea que no se lo indique. Se trata de nociones diferentes y la indicación del valor no sustituye a la individualización, en el mismo modo en que ésta tampoco sustituye a aquella.

c) Así que nosotros debemos leer el inciso 4 como si dijera: "Cuando se pignoraren universalidades o grupos de bienes en la forma señalada en el inciso primero, el contrato de prenda deberá indicar el valor del conjunto de bienes sobre los que recaiga la prenda, y deberá señalar las particularidades tendientes a individualizar los bienes prendados, señalando si son fungibles o no, determinando en el primer caso su especie, cantidad, calidad, graduación y variedad; salvo que las partes acuerden expresamente no asignarle un valor. En este último caso, no será aplicable lo dispuesto en el artículo 1496, N² 2, del Código Civil”. Pero también podríamos prescindir de la cláusula "y deberá señalar las particularidades tendientes a individualizar los bienes prendados, señalando si son fungibles o no, determinando en el primer caso su especie, cantidad, calidad, graduación y variedad", porque, si bien de manera más sintética, su idea esencial ya está dispuesta por el artículo 3 No 3 de la ley, que, en general, obliga a mencionar: " $\mathrm{La}$ individualización o la caracterización de las cosas empeñadas".

En último término, pues, la verdadera alternativa es entre individualización con indicación de valor e individualización sin indicación de valor.

2. La necesidad de individualizar el grupo de bienes o universalidad de hecho pignorados es consecuencia de la necesidad de deber constituirse ambas sobre conjuntos no fungibles ${ }^{70}$. Por ello no sólo se trata de su determinación, pues también las cosas no fungibles se determinan, por mandato del artículo 1461 CC. Ya sabemos que esta individualización del conjunto no debe comprender la de los componentes ${ }^{71}$. Al respecto es aplicable el artículo 3 No 3 de la ley, que ordena mencionar "La individualización o la caracterización de las cosas empeñadas", y, en nuestro caso, las cosas empeñadas son grupos de bienes o universalidades de hecho.

Pero el inciso $4^{\circ}$ del artículo 11 de la ley exige que el contrato de prenda deba señalar "las particularidades tendientes a individualizar los bienes prendados, señalando si son fungibles o no, determinando en el primer caso su especie, cantidad, calidad, graduación y variedad".

Es manifiesta la confusión de planos presente en esta norma.

La exigencia de señalar "las particularidades tendientes a individualizar los bienes prendados" debemos considerarla relativamente a los grupos o universalidades objetos del contrato, sentido en el cual es reiteración de

\footnotetext{
${ }^{70}$ Véase, más arriba, el capítulo IX, 2-4.

${ }^{71}$ Véase, más arriba, el capítulo IX, 3
} 
lo dicho por el No 3 del artículo 3. Pero cuando se manda señalar "si son fungibles o no", la norma se refiere ahora a los componentes del grupo o universalidad. No puede igualmente referirse a uno u otra, porque, como ha quedado establecido, el grupo o universalidad pignorados necesariamente deben ser no fungibles. Lo propio acaece cuando se ordena la determinación de la especie, cantidad, calidad, graduación y variedad de los fungibles.

Debemos, pues, introducir claridad en medio de estas confusiones.

En teoría, hubiera bastado con la individualización del grupo o universalidades pignorados, que es, como acabamos de decirlo, a lo que se refiere en su primera parte el inciso $4^{\circ}$. Ya sabemos que tal individualización se consigue merced a la descripción de las características genéricas de los componentes del grupo o universalidad, más algún ańadido especificador del conjunto, sin descenso a las especificaciones de sus componentes ${ }^{72}$. En consecuencia, interpretaremos que es a ello a lo que se refiere la norma, cuando avanza hasta exigir ciertos señalamientos pertinentes a los componentes de uno u otra.

En primer lugar, se exige el señalamiento de si los componentes son fungibles o no. Es evidente que este tenor, por lo que atañe a los infungibles, no puede agotarse en el sólo señalamiento del hecho, como aparenta decir. ¿Qué sentido tiene meramente señalar que se pignora un conjunto de pinturas no fungibles, si no se describen los caracteres genéricos de las mismas? Con un tal proceder quedaría vulnerado el artículo 1461 CC. Así, pues, lo exigido tiene que ser el señalamiento de contener infungibles el conjunto, seguido de la descripción de los caracteres que son genéricos a todos ellos (pero sin descender a la individualización de cada uno).

Si se trata de fungibles, se dispone señalar su especie, cantidad, calidad, graduación y variedad.

La idea de mencionar la "especie" de los fungibles es claramente un error, porque suele ser imposible mencionarla. De hecho, en los bienes en serie no hay especies, sino unidades individuales, que se distinguen de los demás individuos sólo por ser materia aparte, aunque con forma igual a la de los otros. Así que lo que se quiso decir fue "género", que entendemos como el próximo, al que las unidades pertenezcan.

La "cantidad" concierne, obviamente, al número, peso o medida con que se use cuantificar a los fungibles de que se trata.

La "calidad", aparte de significar el grado de bondad, como óptima, mediana, baja, pésima calidad, también atañe a cualquier atributo, clase, carácter o tipo que se acostumbre a expresar en el comercio ordinario de las cosas de que se trate, y que es variable. Así, por ejemplo, en algunos

${ }^{72}$ Ibíd. 
casos se trata de la marca y del modelo, como en los automóviles o las maquinarias; en otros, de la raza, como en los animales (vacas "Holstein Freisian" u holandesas, Jersey, Simmental, Guernsey, etcétera); también de la variedad genética, como suele usarse en las frutas (palta "Californiana", palta "Hass", etcétera); o bien de los diversos procesos con que algo es producido, como en los metales (cobre electrolítico, cobre térmico, cobre desoxidado, etcétera); o los sistemas de operación que utilizan, como aparatos tales o cuales analógicos o digitales; y así de maneras innumerables.

La "graduación” es generalmente una medida convencional de cantidad por "grados", como la de la concentración del alcohol en los licores espirituosos (grado alcohólico). Su empleo depende de las prácticas industriales y comerciales.

La “variedad” es un subgénero o género dentro del género, que en algunos casos puede quedar incluida en la "calidad". En cualquier caso significa las especialidades que diferencian a grupos de individuos frente a otros, ambos, empero, pertenecientes a una misma clase superior.

Aun se podrían añadir nuevas caracterizaciones no incluidas en la enumeración legal (que debemos entender como ejemplar). Por ejemplo, hay cosas a las que el uso industrial y comercial otorga cierta clasificación por el año de su fabricación, como a los vehículos motorizados; en otros casos es una suerte de código general, distinto del específico de cada individuo, que las empresas inventan convencionalmente para identificar una línea de productos, como en las aeronaves, por ejemplo, DC 10-10, DC 10-15, DC 10-30, etcétera.

Aunque la ley, como vimos, refiere estas caracterizaciones a los componentes fungibles de un conjunto pignorado, sin advertencias especiales, entendemos que esta referencia es en función de construir la individualización del conjunto mismo, para describirlo como no fungible. De esta manera, lo correcto tiene que ser, por ejemplo, una formulación así: "un conjunto de 100 automóviles marca y modelo tales (eventualmente con indicación del año, si se desea restringir el género) depositados, en el momento del presente contrato, en tal parte”, pero sin señalamiento del número del motor de cada uno; o bien: "un ganado de 300 vacunos adultos hembras, de raza "Holstein Freisian" u holandesas, sito, en el momento del presente contrato, en tal finca" y se podría añadir la marca a fuego común a todos los animales, pero no el número de cada uno.

\section{EL CONVENIO DE VALORIZACIÓN DEL CONJUNTO PIGNORADO}

1. La primera parte del inciso $4^{\circ}$ del artículo 11 expresa: "Cuando se pignoraren universalidades o grupos de bienes en la forma señalada en el inciso 
primero, el contrato de prenda deberá indicar el valor del conjunto de bienes sobre los que recaiga la prenda, salvo que las partes acuerden expresamente no asignarle un valor". La disposición, como se lee claramente, atañe al valor de la universalidad o grupo de bienes que es el objeto del contrato prendario. En esta ocasión, pues, la dicción es correcta y precisa. Sin ambigüedades, no atañe al valor de los componentes de la universalidad o grupo. La distinción no es una sutileza, porque ambos valores pueden ser diferentes y el del conjunto no siempre es una sumatoria de los valores singulares. El hecho de tratarse de un conjunto no infrecuentemente, en efecto, implica un valor agregado. Sea como fuere, la referencia legal es inequívoca.

Ahora bien, la norma contiene un mandato a las partes del contrato prendario, en orden a indicar el valor del conjunto pignorado en el contrato ("deberá indicar"). Pero les permite abstenerse de asignarlo. Con esta carga: que si deciden no asignarlo, deben dejar expresa constancia de su acuerdo en tal sentido. El inciso $4^{\circ}$ dice, en efecto: "salvo que las partes acuerden expresamente no asignarle un valor". De esta manera, la simple omisión o preterición del valor, no amparada en la expresión (escrita en el contrato) de un acuerdo en tal sentido, constituye la transgresión de un mandato legal que debe producir algún efecto, que estimamos ser la conversión del contrato de prenda sin desplazamiento sobre grupos de bienes o universalidades de hecho, regida por el artículo 11, en contrato de prenda sin desplazamiento general, porque el artículo 3, que señala las menciones generales de todo contrato de esta especie, no menciona la del valor. Pero esta conversión entrańa un riesgo: como el artículo 3 No 2 obliga a individualizar o caracterizar las cosas empeñadas, no rigiendo el artículo 11, la individualización o caracterización que proceden deben ser relativas a los elementos contenidos en el conjunto que se había intentado pignorar de acuerdo con dicho artículo, así que cuando de alguna manera no aparezcan individualizados o caracterizados tales elementos, ahora el contrato es nulo.

El valor de un conjunto de cosas, como adelantamos no necesariamente es la sumatoria del valor de sus componentes, porque puede haber un valor agregado por el hecho de tratarse precisamente de un conjunto. Cuál sea este valor agregado, es cuestión de hecho. Pero es evidente que el valor del conjunto empieza por la suma del valor de sus componentes, aunque no termine en la mera suma. Ahora bien, el valor que la ley manda indicar para el conjunto en el contrato prendario es convencional y sujeto, por ende, a la estimación de las partes; a salvo la sanción por una simulación, de acuerdo con las reglas generales que rigen esta última figura.

Cumple examinar los efectos de una u otra decisión en la alternativa de indicar el valor del conjunto pignorado o de acordar expresamente 
no asignarle valor alguno. En este capítulo estudiaremos los efectos de la alternativa de haberse asignado un valor; y trasladaremos al siguiente, el análisis de los efectos de la alternativa contraria.

2. El primer efecto de la asignación de valor al conjunto pignorado está indirectamente señalado en el inciso $4^{\circ}$ del artículo 11: consiste en dejar expedita la normal aplicación del artículo 1496 № 2 CC. El inciso $4^{\circ}$ añade: "En este último caso, no será aplicable lo dispuesto en el artículo 1496, $N^{\circ}$ 2, del Código Civil". El "último caso" es precisamente el dicho, de haberse acordado no asignar valor al conjunto. Por consiguiente, indirectamente dice la norma que cuando sí se le asignó valor, el artículo 1496 No 2 CC. recibe normal aplicación.

a) El cual artículo dice: "Elpago de la obligación no puede exigirse antes de expirar el plazo, si no es:/2. Al deudor cuyas cauciones, por hecho o culpa suya, se han extinguido o han disminuido considerablemente de valor. Pero en este caso el deudor podrá reclamar el beneficio del plazo, renovando o mejorando las cauciones". La norma establece una de las excepciones al efecto normal de un plazo apuesto al cumplimiento de una obligación, que es hacerla inexigible hasta pasado el último día del plazo. Pero -dice-se puede exigir aún pendiente éste al deudor, si por hecho o culpa suya ${ }^{73}$, las cauciones que tenía conferidas para seguridad de su deuda, se han extinguido o han disminuido considerablemente de valor. En nuestro caso, la caución que interesa es la prenda y, dentro de ella, la prenda sin desplazamiento de un grupo de bienes o universalidad de hecho.

Una prenda sin desplazamiento sobre grupos de bienes o universalidades de hecho puede extinguirse por cualesquiera de los modos generales de extinguirse toda prenda, por vía principal o por vía accesoria ${ }^{74}$. Nada de

${ }^{73}$ La norma, en efecto, exige que la extinción o disminución de valor de la prenda se deba a un hecho o culpa del deudor; no de terceros. Ahora bien, entre los terceros está el pignorante que caucionó deudas ajenas, que no es, por ende, el deudor (artículo 2388 CC.). En consecuencia, si la prenda se extingue o disminuye su valor por hecho o culpa del pignorante no deudor, interpretada literalmente la norma, no tiene aplicación el No 2 del artículo 1496 CC. Mas, como hay la misma razón para hacerlo aplicable, opinamos que aquella debe entenderse como si hubiera sido escrita así: "Al deudor cuyas cauciones, por hecho o culpa suya o del que la constituyó sin ser deudor, se han extinguido o han disminuido considerablemente de valor". En cuanto a la razón de la norma, véase: CLARo Solar, Luis, Explicaciones de Derecho civil chileno y comparado, X: De las obligaciones, 1 (reimpresión Santiago, Editorial Jurídica de Chile, 1992, V), núm. 263, p. 287, quien reproduce la exposición de Favard al Tribunado, para justificar el artículo 1188 del Código francés, antecedente del artículo 1496 № 2 CCCh. La justificación, o razón, como decimos, es enteramente aplicable al caso que discutimos.

${ }^{74}$ Véase, al respecto, Somarriva Undurraga, Manuel, Tratado de las cauciones (Santiago, Contable Chilena Editores, 1981), pp. 304-308. 
particular tenemos que agregar aquí, a salvo lo que diremos con relación a la extinción de la prenda por la "destrucción completa de la cosa empeñada" (artículo 2406 CC.) en su momento ${ }^{75}$.

Por lo que atañe a la disminución considerable de valor de un conjunto pignorado, digamos que, sea cual sea el valor convencional asignado a él en el contrato prendario, una vez fijado, su disminución (o extinción) está determinada, en primer lugar, por la merma, pérdida o deterioro de componentes que haya sufrido; $y$, en segundo, lugar, por la disminución del valor agregado que ofrece un conjunto por sobre la sumatoria de valores de sus componentes. El cálculo de la disminución de valor es cuestión de hecho; y también lo es la estimación de lo "considerable" que ella sea.

b) A primera vista no se alcanza a percibir por qué el artículo 11 inciso $4^{\circ}$ condiciona la aplicación del artículo 1496 № 2 CC. al hecho de haberse asignado un valor al conjunto pignorado. En el Código Civilno se establece un condicionamiento semejante relativo a la prenda con desplazamiento, única existente para él y pensando en la cual fue escrito, por ende, su artículo 1496 № 2. Esta norma sólo supone que la cosa pignorada tuvo un valor al celebrarse el contrato y se sitúa en el caso de que después disminuya; lo cual constituye una cuestión de hecho, determinable en final de cuentas por el juez, previos unos peritajes tal vez; o bien se sitúa en el caso de que simplemente se extinga la prenda. Pero el señalamiento del valor que la cosa hubo de tener no es elevado al rango de condición para hacer procedente la aplicación del artículo $1496 \mathrm{~N}^{\circ} 2$. El artículo 11 inciso $4^{\circ}$, en cambio, sí exige tal señalamiento para su aplicación.

c) Desde luego debe decirse que no hay fundamento para condicionar la caducidad del plazo en el evento de extinción de la prenda al señalamiento de un valor a lo pignorado. Una cosa no guarda relación con la otra. Que las partes hayan indicado un valor, o que no se lo haya indicado, el hecho objetivo es que, en un momento posterior al contrato, la garantía ha desaparecido por hecho o culpa del deudor, sin la consiguiente extinción de su deuda; y esto debería ser suficiente para hacer aplicable el artículo 1496 No 2.

d) Un aparente fundamento, en cambio, para el condicionamiento de que hablamos en la hipótesis de "disminución considerable" de valor, proviene de la autorización legal de que goza el pignorante de conjuntos, para utilizar, reemplazar, transformar y enajenar sus componentes en el todo o en parte, salvo pacto en contrario (artículo 11 inciso $1^{\circ}$ ). Como consecuencia del ejercicio de tal autorización, el conjunto puede sufrir mermas legítimas, que objetivamente implican una disminución de su valor.

${ }^{75}$ Véase, más abajo, el capítulo XVIII. 
La ley supone, empero, que las mermas de componentes y la consiguiente disminución de valor del conjunto pignorado se ven compensadas por los productos transformados y elaborados, que caen de pleno Derecho bajo prenda (artículo 11 inciso $2^{\circ}$ ) y por los nuevos componentes que ingresan en dicho conjunto en régimen de subrogación prendaria de los que salen (artículo 11 inciso $3^{\circ}$ ). En el interior de un normal proceso fabril o comercial, se considera, pues, que el valor del conjunto pignorado se mantendrá más o menos inalterado y constante en relación con el valor asignado al mismo en el contrato.

Pero la suposición de la ley no es infalible. Podría acontecer que las mermas de componentes originales o sucesivos no se vean compensadas con nuevos componentes, de modo de no operar la subrogación; y que los bienes transformados o elaborados, al ser vendidos, hagan decaer la prenda legal que los afectó, sin que se produzcan nuevos bienes de igual clase que deban quedar bajo el mismo tipo de prenda. Puede acaecer, en consecuencia, que se interrumpa o detenga el flujo normal de egreso e ingreso o de disposición y reposición de componentes y que, por ende, el valor del conjunto pignorado decaiga de manera significativa, hasta incluso desaparecer; y, con todo ello, que se desvanezca la fuerza de la garantía.

Es en previsión de estos acontecimientos que la ley consiente al acreedor aplicar el artículo 1496 No 2 CC., si las partes habían fijado un valor al conjunto pignorado y éste se ve disminuido considerablemente, por hecho o culpa del deudor. El pensamiento de la ley parece ser, pues, que el valor fijado ofrece una referencia cierta para apreciar si lo pignorado ha sufrido una disminución considerable en el mismo.

Sin embargo, como el conjunto pignorado algún valor tuvo que tener en el momento del contrato prendario, una disminución del mismo también puede acontecer posteriormente, lo cual siempre será posible apreciar por el juez, quizá con ayuda de peritos; y entonces nuevamente no se alcanza a entender la subordinación de la aplicación del artículo 1496 No 2 CC. al sólo evento de haber habido valorización en el contrato.

e) Pero como es ese el caso que ahora examinamos, hemos de concluir que la expedita aplicación de aquella norma viene a significar que el pignorante, aun cuando goce de la autorización legal para utilizar, reemplazar, transformar y enajenar en el todo o en parte los componentes del conjunto pignorado (artículo 11 inciso $1^{\circ}$ ), está sometido a la carga de no disminuir considerablemente el valor fijado para él en el contrato prendario, por hecho o culpa suya; lo que debe entenderse en el sentido de no disminuirlo durante intervalos anormales en relación con las normalidades temporales de los flujos de egreso e ingreso de componentes en el proceso fabril o comercial de su empresa. Un "hecho" suyo es cualquier 
conducta que tenga por resultado la merma de componentes; así que incluye sus conductas fabriles o comerciales normales; su "culpa" significa su dolo o su culpa leve, de modo de incluir cualquier conducta anormal que conduzca a la merma.

Con todo, esta conclusión ofrece dificultades, derivadas de la indeterminación del concepto de "disminución considerable" del valor del conjunto pignorado; y de la extensión de los intervalos de tiempo durante los cuales puede haber merma, que incluso disminuya considerablemente el valor de lo pignorado. Esto último es importante, porque la merma de componentes puede ser, en el designio del pignorante, temporal; o puede estar determinada por las alternativas del mercado, como si inesperadamente aumenta la demanda de bienes terminados o disminuye la oferta de materias primas; o los ciclos del mismo, pues suelen presentarse épocas, incluso previsibles, de tales aumentos o disminuciones, etcétera. Incertidumbres como las mencionadas conspiran contra el pignorante frente a un acreedor nervioso, desconfiado o abusador.

Por eso se echa en falta una regulación más matizada de la ley, de sentido algo semejante al del artículo L527-7 del Code de Commerce francés, creado por la Ordenanza No 346, de 23 de marzo 2006, con que se introdujo una amplia reforma al Derecho de garantías. Dicha norma, escrita en tema de una nueva prenda, llamada de "stocks", establece directamente la carga para el deudor (aunque la considera una obligación), de no disminuir por hecho suyo el valor de los "stocks" pignorados. Y ańade que, en caso de que se produjere una disminución del 20\% del valor del “stock", el acreedor puede exigir al deudor que restablezca la garantía o que pague la parte de la deuda que sea proporcional a la disminución; y que, en caso de insatisfacción del extremo pedido, pueda exigirle el pago del total de la deuda, que viene considerada, por consiguiente, como de plazo vencido ${ }^{76}$. En este régimen, de todos modos se advierte la ausencia de un punto: el tiempo de duración de la disminución del "stock" en un $20 \%$ de su valor, por las razones anotadas antes, de que ella pueda ser transitoria y no buscada. En todo caso, ese tiempo no debe ser excesivo,

${ }^{76}$ Artículo L527-7 CCFr.: "Le débiteur tient à la disposition du créancier un état des stocks engagés ainsi que la comptabilité de toutes les opérations les concernant./ Il s'engage à ne pas diminuer de son fait la valeur des stocks./ Lorsque l'état des stocks fait apparaître une diminution de $20 \%$ de leur valeur telle que mentionnée dans l'acte constitutif, le créancier peut mettre en demeure le débiteur, soit de rétablir la garantie, soit de rembourser une partie des sommes prêtées en proportion de la diminution constatée. S'il ne lui est pas donné satisfaction, le créancier peut exiger le remboursement total de la créance, considérée comme échue". 
porque, en un proceso normal, la disminución de existencias no puede durar más que unos pocos días.

3. En cualquier caso, pues, en que se pueda apreciar una extinción de la prenda o una disminución considerable del valor de lo pignorado, debido a hecho o culpa del deudor, el plazo que regía para la deuda garantizada caduca y el acreedor puede exigir el pago de aquélla. Esto no significa, por cierto, que la prenda de valor disminuido se extinga. Por ello, aun podría ser ejecutada, pese a la merma sufrida en su valor.

Pero el deudor puede enervar el efecto precedentemente descrito y conservar, por ende, el beneficio del plazo, si renueva la prenda o la mejora ("renovando o mejorando las cauciones"). En general, esto significa que el deudor debe constituir una nueva caución, que puede ser del mismo género que la anterior, como si da otra prenda, o de distinto género, cuando confiere una hipoteca o una fianza, pero de igual valor que ella ("renovar") o de más valor ("mejorar"). Pero en el caso de la prenda de conjuntos, hay una manera especial que no consiste en conferir una nueva caución, sino en restablecer o mejorar la misma prenda del conjunto disminuido de valor de que se trate; la cual radica en recargar ese conjunto con nuevos componentes hasta llegar al valor asignado, o superarlo. Es una consecuencia propia de la dinámica que ofrecen los conjuntos y universalidades, de aumentar o disminuir sus componentes sin alterarse el conjunto mismo y sin requerir, en este caso, la constitución de una nueva prenda sobre ellos.

4. Cabe dejar constancia que si en el contrato prendario, en el cual se fijó un valor al conjunto, se pactó que el pignorante no haya de poder utilizar, reemplazar, transformar o enajenar los componentes del conjunto pignorado (artículo 11 inciso $1^{\circ}$ ), la contravención del pacto, que haga disminuir el valor de ese conjunto, no se rige por el artículo 1496 No 2 CC., sino por la segunda parte del artículo 18 inciso $3^{\circ}$ de la ley, que no bien general en materia de prenda con desplazamiento, es especial con respecto al mencionado artículo del Código. Dice: "En caso de infracción a lo dispuesto precedentemente, la obligación caucionada se considerará como de plazo vencido"7. La infracción de que habla esta norma es a los deberes

${ }^{77}$ Esta segunda parte, con su expresión "a lo dispuesto precedentemente”, parece referirse únicamente a la primera parte del inciso $3^{\circ}$ del artículo 18 , que, en efecto, es precedente: "Tratándose de derechos, el constituyente estará obligado a evitar su menoscabo o extinción", en circunstancias que alude a todo lo dispuesto precedentemente, y cubre, por ende, los incisos $1^{\circ}$ y $2^{\circ}$ de ese artículo, y, por supuesto, también a esa primera parte de su inciso $3^{\circ}$. Que es como decimos, queda comprobado por cuanto expresa la tercera parte del mismo inciso 30: "Lo anterior es sin perjuicio de las demás responsabilidades civiles o penales que correspondan como consecuencia del abandono de las especies, asi como del menoscabo o extinción de los derechos prendados". La expresión 
y responsabilidad de depositario que tiene el pignorante con respecto a la conservación de la cosa en prenda, indicados en el inciso $1^{\circ}$ del artículo 18 , sin perjuicio de las penas a que por ello queda sometido. Se añade ahí, que esos deberes, responsabilidades y penas no se aplican en el caso en que "legitimamente"se haya procedido conforme al artículo 11; lo cual es natural, porque la prenda de que trata ese artículo, como sabemos, autoriza la utilización, el reemplazo, la transformación y la enajenación de los componentes del conjunto pignorado. Ahora bien, si en el contrato prendario quedó prohibido al pignorante poder ejecutar aquellas operaciones, y las ejecuta, ya no procede "legítimamente" y le afectan, en consecuencia, las responsabilidades civiles y penales generales establecidas por el artículo 18; y, en especial, lo que señala su inciso $3^{\circ}$, en orden a que la deuda garantizada prendariamente vaya considerada como de plazo vencido. Se observará que entonces el punto relativo a la disminución del valor, y a si ésta es considerable o no, deja de ser relevante, pues basta la infracción de la obligación de no hacer que pesaba sobre el pignorante, para que caduque el plazo de su deuda.

5. Lo propio acaece si en el contrato prendario se acordó que los componentes del conjunto pignorado no sean utilizados más que de una manera especificada en el mismo contrato, y el pignorante transgrede ese convenio; pues, en tal caso, caduca el plazo de la deuda y procede la realización de la prenda sin más (artículo 19), vale decir, sin atención a que haya habido disminución de valor o a que no lo haya habido. Así que ahora es indiferente la existencia o inexistencia de un pacto de valorización.

6. El segundo efecto de la asignación de valor al conjunto pignorado es regular la pignoración de pleno Derecho de los bienes transformados a partir de los componentes del conjunto que se pignoró y de los productos elaborados con los mismos componentes, a que se refiere el inciso $2^{\circ} \mathrm{del}$ artículo 11. En otro lugar estudiamos el perfil que ofrece esta figura ${ }^{78}$. Sustancialmente consiste ella en que, pignorado un grupo o universalidad de ciertas cosas que deben dar lugar a productos transformados o elaborados a partir de ellas, merced al proceso fabril a cuyo sometimiento están destinadas, esos productos transformados o elaborados quedan de pleno

"lo anterior" alude a la segunda parte que examinamos: "En caso de infracción a lo dispuesto precedentemente, la obligación caucionada se considerará como de plazo vencido"; y si ésta se refiriera exclusivamente a la primera, concerniente a los derechos, no se explicaría que en la tercera parte se hable del abandono de las especies, que es tratada, no en el inciso $3^{\circ}$ sino en el inciso $2^{\circ}$, y que se mencione expresamente el menoscabo o extinción de derechos, lo que no hubiera sido necesario si la referencia hubiese sido exclusivamente a ellos.

${ }^{78}$ Véase más arriba, el capítulo XII, 2. 
Derecho bajo prenda. El inciso $2^{\circ}$ del artículo 11 no establece ningún límite a la extensión de esta prenda legal. Ahora bien, es normal que el valor de los productos transformados o elaborados sea muy superior al de los elementos a partir de los cuales fue ejecutado el proceso de transformación o elaboración. Pero, en virtud del principio de indivisibilidad de la prenda, es todo el conjunto de los productos transformados o elaborados el que empieza a quedar legalmente en prenda. Si llegare el caso de tener que ser realizada la caución, es todo el conjunto, por consiguiente, el que debe ser vendido. Sin embargo, la asignación de valor al conjunto original en el contrato prendario impone un límite a esta prenda legal sobrevenida, la cual, pues, extendiéndose sobre los productos transformados o elaborados hasta concurrencia del valor inicialmente asignado, sólo puede ser realizada sobre ellos en la medida suficiente para el pago de todos los rubros que la realización debe cubrir, vale decir, el total del monto del crédito, sus intereses y los gastos y costas, si los hubiere (artículo 15). Entretanto llega ese momento, como dijimos, el valor fijado opera como regulador de la prenda legal, en el sentido de que ésta afecta a tantos productos cuantos haya, cuyo valor coincida con el fijado.

\section{EL CONVENIO DE NO VALORIZACIÓN DEL CONJUNTO PIGNORADO}

Los efectos del pacto de no asignar valor al conjunto pignorado en el contrato prendario son exactamente los inversos de aquel con que se le asigna valor.

1. El primer efecto es, por consiguiente, excluir la aplicación del artículo 1496 No 2 CC., como está dicho expresamente en el inciso $4^{\mathrm{o}}$ : "En este último caso, no será aplicable lo dispuesto en el artículo $1496, N^{\circ} 2$, del Código Civil".

a) El "último caso" a que se alude aquí es el de haberse acordado expresamente no asignar valor al conjunto. La exclusión significa que si la prenda de conjuntos, que cauciona cierta deuda a plazo, se extingue o disminuye considerablemente su valor por hecho o culpa del deudor, no por ello puede exigirse el pago de dicha deuda antes de expirar normalmente el plazo entonces vigente (cfr. el artículo 1496 No 2 CC.); en otros términos, el plazo no caduca.

b) La exclusión del artículo 1496 № 2 CC. cuando no se asignó valor a lo pignorado, no se justifica si el evento es la extinción de la prenda. Las razones son las mismas dadas en el caso de haber convenio de valorización. Lo cual significa que fue incorrecto hacer depender la caducidad en aquel evento, de que haya habido o no un tal convenio. Si la prenda desapareció por hecho o culpa del deudor, no se ve por qué, en efecto, no haya de 
protegerse al acreedor con la posibilidad de hacer caducar el plazo de la deuda ahora insegura, únicamente debido a la circunstancia de no haberse valorizado el conjunto constituido en prenda.

c) La exclusión del artículo 1496 No 2 CC. en el caso de no haber habido valorización, en cambio, aparenta justificarse. Las partes acordaron no asignar valor al conjunto pignorado; por ende, no hay una referencia cierta para enjuiciar si lo pignorado ha disminuido considerablemente de valor o no. Se tiene la impresión, pues, de que la ley piensa en no ser posible saber si el conjunto disminuyó de valor, debido a la ausencia de una referencia inicial. Pero es manifiesto el error legal que ello implica, porque el conjunto algún valor tuvo que tener al ser pignorado, aunque no se lo haya indicado en el contrato; $y$, por ende, siempre será posible saber si se disminuyó o no ese valor. Así que no hay justificación real para excluir la procedencia del artículo 1496 No 2 CC. aun en el caso de no haberse indicado valor al conjunto.

d) Mas, ateniéndonos al régimen positivamente establecido por la ley, la consecuencia de la inaplicabilidad de aquella norma al caso que tratamos, significa que el pignorante no está sujeto a la carga de no disminuir considerablemente, por hecho o culpa suya, el valor de lo pignorado; es decir, puede proceder a causar impunemente una tal disminución. A salvo, sin embargo, que tenga prohibido, por pacto prendario, utilizar, reemplazar, transformar o enajenar los componentes del conjunto pignorado (artículo 11 inciso $1^{\circ}$ ); o bien que haya pactado no utilizarlos sino de una manera especificada en dicho contrato (artículo 19); porque la contravención de estos pactos, haya o no disminución en el valor de lo pignorado, le acarrean la caducidad del plazo de su deuda, no por aplicación, ciertamente, del artículo 1496 No 2 CC., mas como consecuencia directamente prevista en la nueva ley misma. Sobre esto tratamos en otro lugar ${ }^{79}$.

2. El segundo efecto es la ilimitación de la prenda de pleno Derecho establecida por el inciso $2^{\circ}$ del artículo 11 sobre los bienes transformados a partir de los componentes del conjunto que se pignoró y de los productos elaborados con los mismos componentes. En el caso, pues, recobra su plena vigencia el principio de indivisibilidad de la prenda; y es todo el conjunto de bienes transformado y productos elaborados el que resulta bajo prenda legal.

3. La fijación de valor al conjunto pignorado o la ausencia de tal fijación son indiferentes, en cambio, para la subrogación prendaria a que se refiere el inciso $3^{\circ} \mathrm{del}$ artículo 11 . Como se recordará, de acuerdo con esta norma, los componentes que salgan de la universalidad o grupo de bienes

${ }^{79}$ Véase, más arriba, el capítulo XI, 1. 
pignorados quedan subrogados por los que posteriormente lo integren; y esta subrogación opera "hasta la concurrencia del total constituido en prenda", vale decir, hasta concurrencia del total de componentes originales del conjunto objeto de contrato prendario. En este caso, pues, la ley señala ella misma un criterio regulador de la subrogación prendaria ${ }^{80}$. De ello se colige que no es posible acudir al criterio limitativo derivado del valor asignado al conjunto, como sí lo hubiera sido cuando la ley hubiese callado sobre el punto. En consecuencia, aunque se haya asignado valor al conjunto en el contrato prendario, la subrogación queda graduada sólo por el total original de componentes del conjunto constituido en prenda, sin consideración al valor fijado; y con mayor razón queda graduada por aquel criterio cuando ningún valor fue entonces asignado.

La diferencia de régimen que en lo tocante a su limitación ofrecen la prenda legal del inciso $2^{\circ}$ del artículo 11 y la subrogación prendaria de su inciso $3^{\circ}$ es explicable. En el caso de la prenda legal hay sustitución de unos bienes en estado primario por otros transformados o elaborados cuyo valor normalmente es muy superior al de aquéllos; y es por ende lógico que el regulador de la prenda legal de los segundos sea el valor asignado a los primeros; mientras que en la subrogación prendaria hay sustitución de unos bienes por otros de su misma especie, de modo que el valor de ambos es el mismo (a salvo las variaciones procedentes de factores extrínsecos, como la inflación); y lo lógico ahora es que el regulador de la subrogación sea la cantidad de los bienes subrogados.

\section{EXTINCIÓN DE LA PRENDA SIN DESPLAZAMIENTO SOBRE GRUPOS DE BIENES O UNIVERSALIDADES DE HECHO DEBIDA A LA DESTRUCCIÓN COMPLETA DE UNOS U OTRAS}

De los diferentes modos por las cuales puede extinguirse una prenda, nos interesa especialmente aquel que consiste en la "destrucción completa de la cosa empeñada" (artículo 2406 CC.). Entre otras materias, este punto tiene su incidencia en el tema de la aplicación del artículo 1496 № 2 CC., cuando se valorizó lo pignorado en el contrato y la prenda se extinguió precisamente por destrucción completa de la cosa empeñada ${ }^{81}$.

1. Al respecto, es preciso distinguir entre la destrucción del grupo o universalidad mismos y la destrucción de sus componentes o cosas singulares que lo integran.

a) Cuando los componentes son corporales, la destrucción de que habla el artículo 2406 CC. es física. Si los componentes son cosas incorporales,

\footnotetext{
${ }^{80}$ Véase, más arriba, el capítulo XIII, 2, d).

${ }^{81}$ Véase, más arriba, el capítulo XVII, 2, a).
} 
como una cartera de créditos, por su destrucción análogamente debemos entender la extinción proveniente de cualesquiera de la causas legales o modos de extinguir obligaciones (entre las cuales está la destrucción completa del objeto material del crédito $^{82}$ ).

b) Pero la destrucción física de las cosas corporales o jurídica de las incorporales componentes de un grupo de bienes o universalidad no implica por sí sola la destrucción de uno u otras mismos, mientras resten al menos dos componentes.

La base material de un tal grupo o universalidad es la pluralidad de cosas reunidas. Por definición, una pluralidad sólo puede empezar con el mínimo de dos cosas; de forma que ella deja de existir cuando sus muchos componentes quedan reducidos a uno o a cero; y es en tal caso que quedan destruidos el grupo o la universalidad.

Esta contracción a uno o a cero puede deberse a causas físicas incidentes en los componentes, como el incendio del local en que se hallaba el conjunto, que destruye sus componentes; o un terremoto que provoca la misma consecuencia; o la plaga que acaba con el trigo o el rebaño pignorados; o el hurto, etcétera. Pero también a causa llamémoslas jurídicas, que sin destruir materialmente los componentes, los hacen salir del conjunto al que pertenecen, el cual queda, él sí, físicamente destruido, como acontece cuando el dueño del conjunto enajena todos sus componentes.

De acuerdo con lo expuesto, la prenda sobre grupos de bienes o universalidades de hecho no se extingue merced al artículo 2406 CC. por la destrucción física o por la extinción de algunas o muchas de las cosas corporales o incorporales singulares que los componen, mientras permanezcan incólumes al menos dos de ellas. Pero sí se extingue esa prenda como consecuencia de la mengua del conjunto a uno o a cero, por cualquier causa, porque en tal caso sí se destruye completamente el conjunto.

2. Pero la prenda de grupos o universalidades ofrece esta peculiaridad: el pignorante se halla legalmente autorizado para utilizar, reemplazar, transformar y enajenar sus componentes en el todo (o en parte), salvo pacto en contrario (artículo 11 inciso $1^{\circ}$ ). Estas operaciones por su naturaleza pueden conducir a una merma de los componentes corporales o incorporales del conjunto pignorado. Mientras esta merma sea parcial, el conjunto permanece y la prenda no se extingue. Para cuando la merma sea total, debemos distinguir.

a) Si la merma se debe a la transformación de todos los componentes originales en otros, que la ley llama "bienes transformados", o a la integración física de componentes en unos todos distintos, que la misma ley

${ }^{82}$ Que, debe observarse, no está pignorado, porque aun no ha sido pagado. 
denomina "productos elaborados", puesto que ambos dejan de pertenecer al grupo o universalidad iniciales, los cuales quedan vacíos, se destruyen y por ello se extingue la prenda. Mas, como sabemos ${ }^{83}$, la misma ley subsana este inconveniente, con el establecimiento de una nueva prenda de pleno Derecho sobre los bienes transformados y los producto elaborados (artículo 11 inciso $2^{\circ}$ ). Si la merma fue parcial, por cierto coexisten dos prendas: la original sobre el conjunto subsistente, puesto que éste no ha quedado destruido, y la legal sobre los bienes transformados y los productos elaborados.

b) Cuando la merma se debió a la "salida" de todos los componentes del grupo o universalidad inicialmente pignorados, puesto que la ley establece una subrogación legal de los componentes salidos por los que posteriormente lo integren (artículo 11 inciso $3^{\circ}$ ), no se producen ni la destrucción del conjunto ni la extinción de la prenda original, precisamente porque de subrogación se trata. Sin embargo, debe advertirse que en ello hay una anomalía. Cuando son todos los componentes del conjunto los que "salen" de él, técnicamente se extingue ese conjunto. Pero la ley se despreocupa de este efecto y fulmina la subrogación sin atender a si la "salida" fue total o sólo parcial. Así que cuando fue total, subsiste un conjunto vacío que espera ser recargado con nuevos componentes subrogantes.

3. La nueva ley no obliga al pignorante a tomar un seguro contra siniestros de los objetos pignorables según la misma ley. Esta aserción sigue completamente válida en el caso de pignoración de grupos o universalidades. Naturalmente, las partes del contrato prendario pueden acordar que el pignorante deba tomar y mantener un seguro y financiarlo. $\mathrm{Al}$ respecto, debe distinguirse el seguro del conjunto y el seguro de los componentes, para deliberadamente incluir a ambos en el contrato.

Por otra parte, puede acaecer que la extinción total del grupo o universalidad por destrucción total de sus componentes y la destrucción parcial de estos últimos dé lugar legalmente a una indemnización no proveniente de seguros, sino de la condena recaída en el responsable aquiliano de la destrucción.

Ahora bien, en estos casos, el artículo 15 de la ley establece que el derecho del acreedor a pagarse del total del monto del crédito, incluidos los intereses, gastos y costas, si los hubiere, con la preferencia establecida en el artículo 2474 CC.: "se extenderá, además, al valor del seguro sobre la cosa dada en prenda, si lo hubiere, y a cualquier otra indemnización que terceros deban por daños y perjuicios que ella sufriere". Esta norma, en lo relativo al seguro, es aplicación del artículo 555 C. de C.: "La cosa que es materia del

${ }^{83}$ Véase, más arriba, el capítulo XII, 2. 
seguro es subrogada por la cantidad asegurada para el efecto de ejercitar sobre ésta los privilegios e hipotecas constituidos sobre aquélla". El cual, pues, técnicamente establece una subrogación de la cosa pignorada por la "cantidad asegurada". El antes transcrito artículo 15 habla de una "extensión" del privilegio de pagarse con preferencia el acreedor; pero algo impropiamente, porque la idea de "extensión" supone que lo extendido tiene una base que se conserva, y desde la cual es precisamente extendido a otra base; pero, al menos en el caso extremo de una destrucción total, no es que la prenda se extienda desde el objeto original, que ahora no existe, hacia un nuevo objeto -el valor del seguro-, sino que cambia de objeto; y en esto es en lo que consiste una subrogación. Así que en la descripción del artículo 15 no debemos ver un cambio en la técnica del Código de Comercio, de modo que también ahí estamos en presencia de un subrogación; lo cual vale asimismo para las indemnizaciones.

\section{LA FUERZA GARANTIZADORA \\ DE LA PRENDA DE GRUPOS O UNIVERSALIDADES}

La nueva ley ha introducido una forma prendaria muy flexible y dinámica, teóricamente llamada a prestar importantes servicios a la industria y al comercio que llaman de "capital de riesgo", pero no sólo a ellas. Quien necesita crédito y ofrece como garantía la universalidad de sus existencias -resumamos en este término los diversos objetos mencionados a título ejemplar por el artículo 11- o un grupo de ellas, que son la base material de su giro, puede desarrollar su operación fabril o comercial igual a como las desarrollaría si no hubiera dado garantía; es decir, puede elaborar las materias primas para fabricar los productos finales previstos en el dicho giro, y puede comercializar tales productos, o sea, enajenarlos, ora a sus distribuidores, ora a sus clientes directos. En todos los eventos, las cosas corporales que, como conjunto fueron pignoradas originalmente, van dispuestas físicamente, merced al proceso fabril, y jurídicamente, con la venta de los productos intermedios o finales. Pero la garantía subsiste, porque los productos transformados y elaborados quedan sometidos ellos mismos a una prenda legal, o porque los componentes salidos del conjunto pignorado se ven prendariamente subrogados por los nuevos integrantes que ingresaron. Así que, por diversas vías, la garantía prendaria permanece sobre un todo que se renueva incesantemente.

El diseño que la ley chilena ha impreso en la garantía sobre grupos o universalidades cuida sólo de definir sus extremos que favorecen al pignorante -normalmente el deudor-, en cuanto a sus facultades dispositivas sobre el contenido del grupo o universalidad, pero ha omitido estatuir completamente sobre aquellos que deben proteger al acreedor. El 
punto es el siguiente: constituida la prenda, el pignorante está facultado para disponer física y jurídicamente del contenido original del grupo o universalidad pignorados, o del contenido ingresado posteriormente en él. En el caso extremo, puede acaecer, pues, que, llegado el momento del desposeimiento del pignorante, uno y otra estén vacíos o con escasísimos componentes. Como lo que una vez salió definitivamente del conjunto, queda libre de prenda, he ahí que el pignorante, aunque ha conservado su derecho real sobre el conjunto, en términos efectivos no podrá ejecutarlo o sólo podrá hacerlo sobre una pequeña porción de las cosas corporales o incorporales subsistentes en él. También puede ocurrir que sin aún llegar el momento del desposeimiento al deudor, y vigente el plazo de la deuda, los componentes disminuyan significativamente, sin normal reposición subsiguiente o previsible en el brevísimo plazo. De hecho, pues, la garantía, o se ha esfumado o, al menos, aparenta haberse esfumado.

En otras legislaciones suelen tomarse algunos resguardos paras tales eventos. Así, por ejemplo, en el artículo 22 de la ley española de 16 de diciembre de 1954: De hipoteca mobiliaria y prenda sin desplazamiento ${ }^{84}$ está previsto que cuando se hipotecan las mercaderías y materias primas destinadas a la explotación propia de un establecimiento, el "deudor viene obligado a tener en el establecimiento mercaderias o materia primas en cantidad y valor igual o superior al que se haya determinado en la escritura de hipoteca, reponiéndolas debidamente con arreglo a los usos del comercio". Y se concede un derecho de inspección sobre el giro y tráfico del establecimiento, sin estorbar su normal desenvolvimiento, al acreedor. En esta disposición se inspira el artículo 30 de la Ley de hipoteca inmobiliaria y prenda sin desplazamiento de posesión de Venezuela ${ }^{85}$. En el fondo es la misma solución adoptada por el artículo 2342 del Code Civil, introducido por la Ordenanza No 346, de 23 de marzo $2006^{86}$, con que se reformó el Derecho de garantías ${ }^{87}$. Según tal disposición, si la prenda tiene cosas fungibles

${ }^{84}$ Sobre la hipoteca mobiliaria y la prenda sin desplazamiento españolas: DíEz Picazo, Luis - Gullón, Antonio, Sistema de Derecho civil (6a edición, Madrid, Tecnos, 1997), III, pp. 570-588.

${ }^{85}$ Publicada en la Gaceta Oficial, número extraordinario 1.575, de 4 de abril de 1973.

${ }^{86}$ En la nomenclatura francesa, "ordenanza" es el término que se aplica a la legislación delegada, así que es equivalente al decreto con fuerza de ley chileno.

${ }^{87}$ Un panorama de dicha reforma en: Ríos LABBÉ, Sebastián, La reforma del Derecho de garantías en Francia. Puesta al día necesaria y fracaso parcial de una reforma de conjunto, en Revista de Derecho Privado "Fernando Fueyo Laneri" (Santiago, diciembre de 2006), pp. 89-116. También en Caprile Biermann, Bruno, La reforma al derecho de las cauciones en Francia: perspectivas para un devenir en Chile (en prensa en: Estudios de Derecho Civil III: "Jornadas Chilenas de Derecho Civil, Valparaíso, 2007"). 
por objeto, el constituyente puede enajenarlos, cuando la convención lo autoriza, mas con cargo de reemplazarlos por una cantidad igual de cosas equivalentes ${ }^{88}$. De acuerdo con estos criterios, pues, al derecho de disponer se añade una obligación de reponer, de manera que el conjunto se mantenga permanentemente completo en cantidad y valor, con respecto a los términos originales de la pignoración. Pero en la materia específica de la nueva prenda francesa de "stocks" 89 , la solución ofrece varias modalidades. Ya antes fue recordada. Pero insistamos en que el artículo L527-7 del Code de Commerce, también creado por la Ordenanza No 346, de 23 de marzo 2006, impone una obligación al deudor, en orden a tener a disposición del acreedor un estado de los "stocks" pignorados y la contabilidad de las operaciones a ellos concernientes; y también lo obliga a no disminuir por hecho suyo el valor de tales "stocks". En el evento de producirse una disminución del 20\% de su valor, el acreedor puede exigir al deudor que restablezca la garantía o que pague la parte de la deuda que sea proporcional a la disminución; y, en caso de insatisfacción del extremo pedido, puede exigirle el pago del total de la deuda, que viene considerada, por consiguiente, como de plazo vencido ${ }^{90}$.

Por su parte, el artículo 9, II de la Ley interamericana modelo sobre garantías mobiliarias ${ }^{91}$ establece la obligación de suspender el pignoratario el ejercicio de sus derechos de uso y disposición de los bienes pignorados para el curso normal de sus operaciones si el acreedor lo notifica de su intención de proceder a la ejecución de la garantía. Esta norma ha sido adoptada en Guatemala, en el artículo 14 letra b) de su Ley de garantía

${ }^{88}$ Artículo 2342 CCFr.: "Lorsque le gage sans dépossession a pour objet des choses fongibles, le constituant peut les aliéner si la convention le prévoit à charge de les remplacer par la même quantité de choses equivalentes".

${ }^{89}$ Sobre esta prenda: Legeais, Dominique, Sûretés et garanties du crédit ( $5^{\mathrm{a}}$ edición, Paris, LGDL., s.d. [pero 2005]), pp. 366-370.

${ }^{90}$ Artículo L527-7 CCFr.: "Le débiteur tient à la disposition du créancier un état des stocks engagés ainsi que la comptabilité de toutes les opérations les concernant./ Il s'engage à ne pas diminuer de son fait la valeur des stocks./ Lorsque l'état des stocks fait apparaître une diminution de $20 \%$ de leur valeur telle que mentionnée dans l'acte constitutif, le créancier peut mettre en demeure le débiteur, soit de rétablir la garantie, soit de rembourser une partie des sommes prêtées en proportion de la diminution constatée. S'il ne lui est pas donné satisfaction, le créancier peut exiger le remboursement total de la créance, considérée comme échue".

${ }^{91}$ Esta llamada "ley" es un texto articulado sobre garantías mobiliarias aprobado por la Sexta Conferencia Interamericana Especializada sobre Derecho Privado Internacional, celebrada en Washington, del 4 al 8 de febrero de 2002. Se la ve en: http:// www.natlaw.com/hndocs/mlcidipviversionfinal.pdf . Las Conferencias Interamericanas Especializadas son reuniones periódicas de expertos, promovidas y organizadas por la Organización de Estados Americanos. 
inmobiliaria, aprobado merced al Decreto No 51, de 24 de octubre de 2007, en vigencia desde el 1 de enero de 2008.

En el Perú, el artículo 7 de la Resolución No 430-97, emitida el 16 de junio de 1997, por el Superintendente de Banca y Seguros, para reglamentar el artículo 231 de la Ley General del Sistema Financiero y del Sistema de Seguros y Orgánica de la Superintendencia de Banca y Seguros, con la cual se estableció una prenda global y flotante, dispone que son obligaciones del pignorante: levantar un inventario detallado, cuantitativo y cualitativo de los bienes gravados al momento del otorgamiento de la prenda global y flotante (artículo 7 No 2); poner en conocimiento del acreedor la sustitución de los bienes objeto de la prenda global y flotante, y constituir inventario sobre los mismos (artículo 7 No 6); comunicar al acreedor cuando los bienes fungibles que se mantienen en prenda se hayan deteriorado, con indicación de las causas del hecho, y proceder a su inmediata sustitución conforme con los acuerdos entre las partes (artículo 7 No 7); no celebrar nuevas prendas globales y flotantes sobre bienes de similar naturaleza, sin comunicar previamente este hecho al acreedor (artículo 7 No 8); no variar el lugar donde permanecerán los bienes afectos a prenda global y flotante sin recabar la conformidad previa y escrita del acreedor (artículo 7 No 9); mantener un "stock" mínimo de bienes de similar naturaleza, y no sujetos a otras prendas, que permita la sustitución inmediata de los bienes afectos a la garantía en caso de disposición, pérdida, robo, deterioro u otro evento similar (artículo 7 No 10).

En el Derecho inglés, en el cual nació la "floating charge", tiene especial importancia la llamada "cristalización" ("chrystallissation") de la prenda ${ }^{92}$, término metafórico éste que podemos sustituir por "fijación”, para designar la conversión de una "floating charge" en "fixed charge o "specific charge". En el momento así llamado, cesa la habilidad del deudor para gestionar libremente los bienes objeto de la prenda, en orden a aplicarlos al giro ordinario, fabril o comercial, de guisa que el conjunto de los que haya resulta inmovilizado, estabilizado, sujetado o precisamente fijado a la prenda, en función de su realización. Esta fijación tiene lugar, por cierto, con la declaración de quiebra, pero también con la insolvencia, el cese en un pago, aunque no se haya pedido la quiebra, y otras causas. Fijada la prenda, se somete los objetos pignorados a una administración especial (“administrative receivership") ${ }^{93}$.

\footnotetext{
${ }^{92}$ Sobre la "cristalización", véase: Galanti, Enrico, Garanzia non possessoria e controllo della crisi di impresa: la "floating charge" e l' administrative receivership" (Banca d'Italia, Quaderni di Ricerca Giuridica della Consulenza Legale, No 51, 2000), pp. 66-72.

${ }^{93}$ Sobre este administrador, ibíd., pp. $97-116$
} 
Como se ve, hay una variada gama de cautelas posibles, destinadas a mantener la integridad del contenido del conjunto pignorado. No es que en la ley chilena estén ellas completamente ausentes. Pero ofrecen limitaciones.

Desde luego está la garantía que ofrece la ley penal, pues cuando el pignorante obre con dolo, en términos de provocar el vaciamiento del conjunto con el propósito de menoscabar la prenda y burlar al acreedor, puede cometer el delito previsto por el No 2 del artículo 39: "Serán castigados con las penas señaladas en el artículo 473 del Código Penal: 2) El deudor prendario y el que tenga en su poder la cosa constituida en prenda en conformidad a esta ley que, defraudando al acreedor prendario, la altere, oculte, sustituya, traslade o disponga de ella". Mas si el pignoratario obró sin dolo el delito no se comete. Y desde el punto de vista civil, son los resguardos para ese caso los que interesan.

La ley concede un resguardo civil al pignoratario, en orden a dejarle expedita la aplicación del artículo 1496 No 2 CC., que le consiente tener por caducado el plazo de la deuda y exigir su cumplimiento al deudor, cuando el valor de la garantía ha disminuido considerablemente; pero esta expedición sólo opera si previamente el conjunto fue valorizado en el contrato prendario ${ }^{94}$.

En el resto están las cautelas generales de la nueva ley. De acuerdo con el artículo 17, es dable convenir que las cosas dadas en prenda no puedan gravarse o enajenarse, y la infracción de este convenio da derecho al acreedor para exigir la inmediata realización de la garantía; pero un acuerdo semejante es contrario al régimen de la prenda de conjuntos regulada por el artículo 11, y a lo más se justificaría cuando estos se componen de infungibles, como, por ejemplo, una colección de objetos artísticos. En conformidad con el artículo 19, si se ha convenido un lugar en donde deba mantenerse la cosa empeńada, ésta no podrá ser trasladada; y si se ha convenido que la cosa empeñada se utilice de una forma especificada en el contrato, ella no podrá utilizarse de forma distinta a lo pactado; a menos que el acreedor consienta en lo contrario o que un tribunal decrete el traslado o un uso distinto; en caso de infracción, el acreedor puede exigir la inmediata realización de la prenda. Esta vez, el convenio de mantener el conjunto, como tal, en un lugar determinado no atenta contra el régimen de la prenda regulada por el artículo 11, siempre que él sea referido precisamente al conjunto y no a sus componentes, que necesariamente deben salir de él para su transformación o enajenación. El convenio, pues, significaría que, mientras no sea necesario disponer física o jurídicamente

${ }^{94}$ Véase, más arriba, el capítulo XVII. 
de los componentes, ellos deban permanecer en el lugar designado; y que los bienes que nuevamente ingresan en dicho conjunto, también deban ser momentáneamente guardados en él. Por el contrario, podría atañer permanentemente a los componentes en el caso de ser infungibles. Merced a lo dispuesto por el artículo 20, el acreedor prendario tiene derecho para inspeccionar en cualquier momento, por sí o por delegado, los efectos dados en prenda, vale decir, los conjuntos y sus componentes; y esta facultad sí tiene importancia cautelar.

Además de la aplicación de estas cautelas generales, el acreedor dispone de las medidas precautorias tipificadas en el Código de Procedimiento Civil, como el secuestro (artículo 290 No 1), el nombramiento de interventores (No 2), la retención (No 3) y la prohibición de celebrar actos y contratos (No 4). Pero, como es bien sabido, estas medidas son muy restringidas. Por lo demás, la declaración de quiebra, de acuerdo con las reglas generales, produce el desasimiento del deudor (artículo 64 lib. IV C. de C.), la inoponibilidad de sus actos a título gratuito (artículo 74 lib. IV C. de C.) y la rescindibilidad de aquellos a título oneroso (artículos 74 y 75 lib. IV C. de C. en relación con el artículo 2469 CC.), celebrados durante el período sospechoso; si bien la inoponibilidad y la rescisión no afectan a los terceros que se encuentren en el caso previsto por el artículo 25 inciso $3^{\circ}$ de la ley ${ }^{95}$.

En ausencia, pues, de cautelas más específicas de los derechos del acreedor, no queda más que éste las provea en el contrato prendario. Por consiguiente, esta materia ha de quedar ampliamente entregada a la inventiva de los abogados asesores.

[Recibido el 3 de marzo y aceptado el 9 de abril de 2008].

\section{BIBLIOGRAFÍA}

Álvarez Osben, Alberto, Diccionario de términos contables, comerciales y computacionales (Valparaíso, Ediciones Universitarias de Valparaíso, 1987).

Bertalanffy, Ludwig von, Teoría general de los sistemas. Fundamentos, desarrollo,

${ }^{95}$ Artículo 25 inciso 30: "Sin embargo, el derecho de prenda no será oponible contra el tercero que adquiera el bien empeñado por venta al detalle en una fábrica, feria, bolsa de productos agropecuarios, casa de martillo, tienda, almacén u otros establecimientos análogos en que se vendan cosas muebles de la misma naturaleza". Esta disposición no debe impedir la inoponibilidad establecida por el artículo 74 lib. IV C. de C. ni la rescisión de los acto de enajenación misma, a que en definitiva se refiere el artículo 75 lib. IV C. de C.; pues sólo impone una inoponibilidad del derecho real contra los terceros adquirente en las circunstancias que indica. 
aplicaciones (1968, traducción castellana, México, Fondo de Cultura Económica, reimpresión 1991).

Biondi, Biondo, La dottrina giuridica della 'universitas' nelle fonti romane, en Bulletino dell'Istituto di Diritto Romano 61 (Roma, 1958).

Biondi, Biondo, Los bienes (1956, traducción castellana, Barcelona, Bosh, s. d. [pero 1961]).

Bonfante, Pietro, La formazione scolastica della dottrina dell' "universitas" (1906), después en El mIsmo, Scritti giuridici vari (Torino, UTET., 1926), I, pp. 307323.

Caprile Biermann, Bruno, La reforma al derecho de las cauciones en Francia: perspectivas para un devenir en Chile (en prensa en: Estudios de Derecho Civil III. Jornadas Chilenas de Derecho Civil, Valparaiso, 2007).

Claro Solar, Luis, Explicaciones de Derecho civil chileno y comparado, X: De las obligaciones, 1 (reimpresión Santiago, Editorial Jurídica de Chile, 1992, V).

Composto Canales, Arnolfo, Manual de Contabilidad para abogados (2a edición, Santiago, Editorial Jurídica de Chile, 1996).

Cruz Moreno, María, La prenda irregular (s. 1. [pero Madrid], Centro de Estudios Registrales del Colegio de Registradores de la Propiedad y Mercantiles de España, s. d [pero 1995]).

dell'Oro, Aldo, Le cose colletive nel Diritto romano (Milano, Giuffré, 1963).

Díez Picazo, Luis - Gullón, Antonio, Sistema de Derecho civil (6a edición, Madrid, Tecnos, 1997), III.

GalANTI, Enrico, Garanzia non possessoria e controllo della crisi di impresa: la "floating charge" el'"administrative receivership"(Banca d'Italia, Quaderni di ricerca giuridica della consulenza legale, No 51, 2000).

Gigen, John, Teoría general de sistemas (2a edición, Ciudad de México. Trillas, 1987).

GuZmán Brito, Alejandro, Destrucción y especificación de una cosa corporal, en Estudios de Derecho Civil III. Jornadas Chilenas de Derecho Civil, Valparaíso, 2007 (en prensa).

GuZmán Brito, Alejandro, Las cosas incorporales en la doctrina y en el Derecho positivo (2。 edición, Santiago, Editorial Jurídica de Chile, 2006).

Guzmán Brito, Alejandro, Las prendas ordinaria y sin desplazamiento de la ley $N^{o}$ 20.190 , recaidas en cosa ajena, en el libro-homenaje que la Universidad Diego Portales dedicará al profesor Christian Larroumet (en prensa).

Historia de la ley No 20.190 (Biblioteca del Congreso Nacional, 5 de junio de 2007) [visible en: http://www.bcn.cl/histley/lfs/hdl-20190/HL20190.pdf].

JohANSEn BertogLio, Óscar, Introducción a la teoría general de sistemas (1991, México, Limusa-Noriega, 18 a reimpresión s. d. [pero 2000]).

Lecaros Sánchez, José Miguel, Las cauciones reales. Prenda e hipoteca (Santiago, Metropolitana Ediciones, 2001).

LeCARos SánChez, La prenda civily las prendas especiales (2a edición, Santiago, Metropolitana Ediciones, 2005).

Legeais, Dominique, Sûretés et garanties du crédit (5 $5^{\mathrm{a}}$ edición, Paris, LGDL., s.d. [pero 2005]).

Marsal Guillamet, Joan, Las prendas flotantes. Un término polisémico, en Lauroba, M. Elena - MARsAL, Joan (editores), Garantías reales mobiliarias en Europa (Madrid, Marcial Pons, 2006). 
MentXaca, Rosa, La pignoración de colectividades en el Derecho romano clásico (s. 1. [pero Bilbao], Servicio Editorial de la Universidad del País Vasco, s. d. [pero 1986]).

Norma Internacional de Contabilidad (NIC) No 2: "Inventarios" (actualizada al 31 de diciembre de 2005), "Definiciones", 6, en Normas Internacionales de Información Financiera (NIIF) 2006 (traducción castellana autorizada, London, International Accounting Standards Board, s. d. [pero 2006]).

Ríos Labbé, Sebastián, La reforma del Derecho de garantías en Francia. Puesta al día necesaria y fracaso parcial de una reforma de conjunto, en Revista de Derecho Privado "Fernando Fueyo Laneri" (Santiago, diciembre de 2006), pp. 89-116.

Silva Palavecinos, Berta, Fundamentos del sistema contable: nuevos enfoques y actualización (Valparaíso, Ediciones Universitarias de Valparaíso, 2006).

Somarriva Undurraga, Manuel, Tratado de las cauciones (Santiago, Contable Chilena Editores, 1981).

Veiga Copo, Abel Benito, Prenda 'omnibus', prenda rotativa de acciones y garantía flotante, en Revista de Derecho Bancario y Bursátil, Año 20, № 82 (Valladolid, 2005), pp. 33-74. 
